
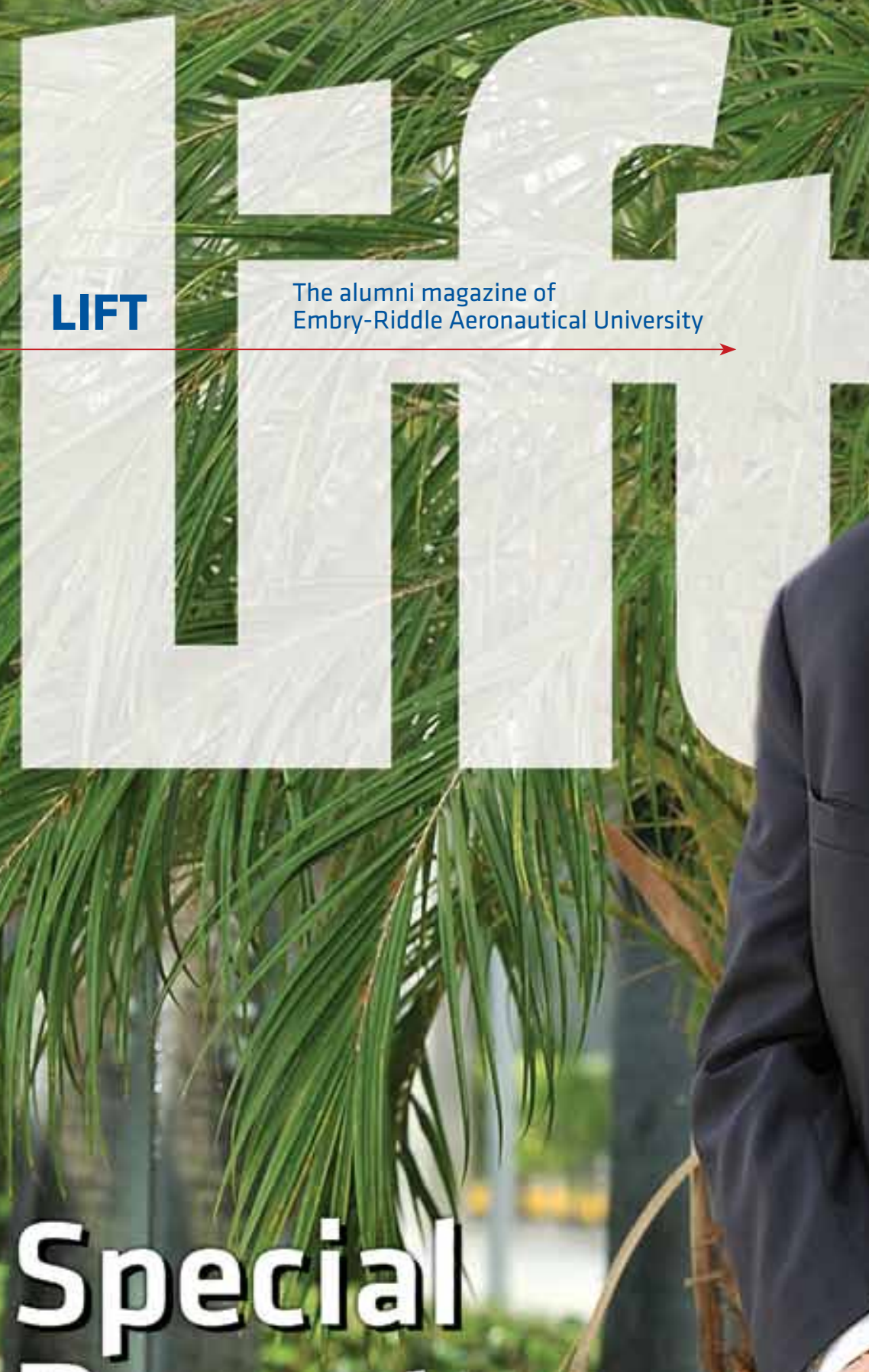

Report

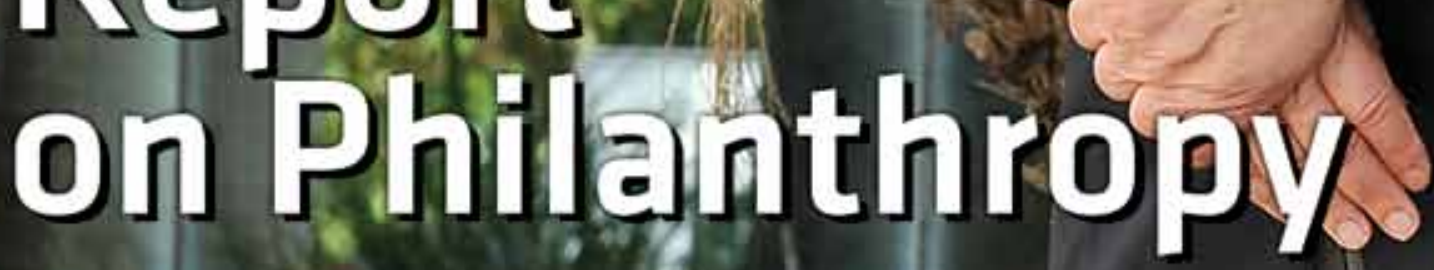

The Emil Buehler Perpetual Trust's $\$ 2$ million gift helps Embry-Riddle train the next generation of maintenance technicians and managers 


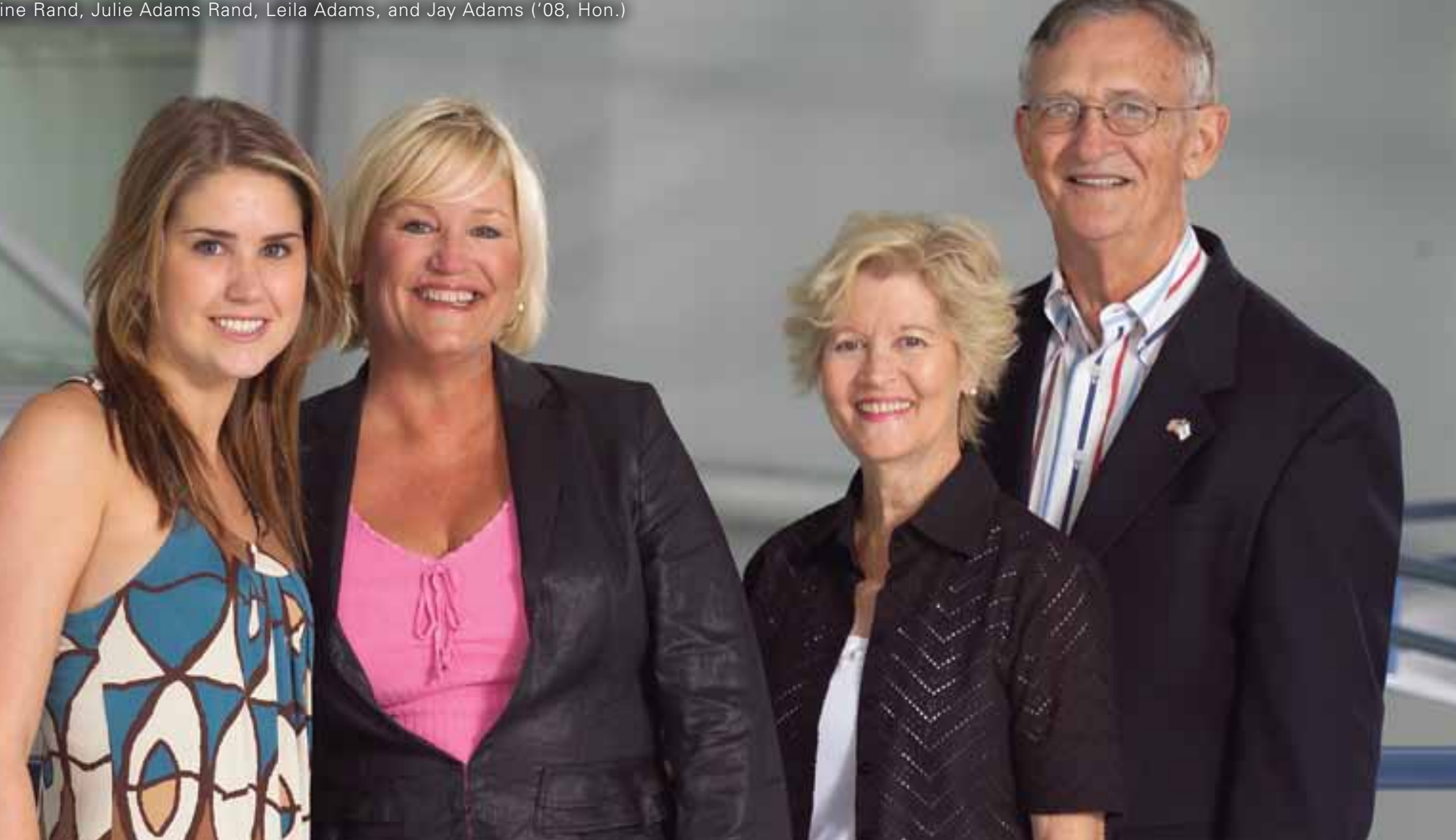

FLORIDA

ARIZONA

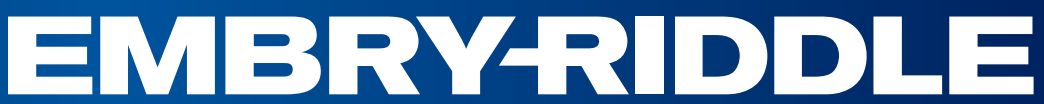

WORLDWIDE

\section{Aeronautical University}
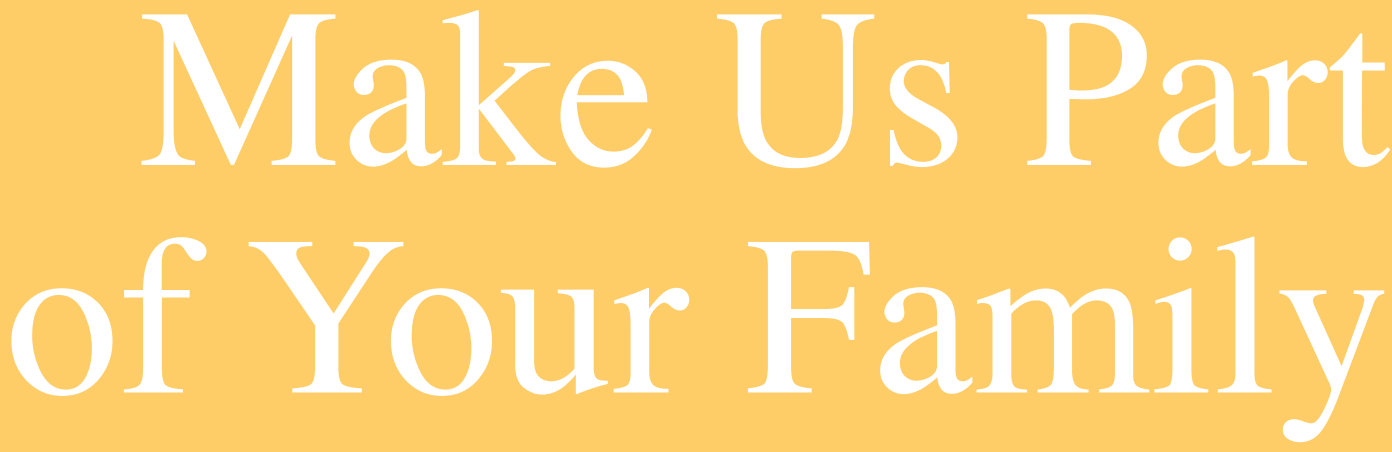

When you make a planned gift to Embry-Riddle, you join a very special family dedicated to making a difference in the lives of those who will shape the future of aviation and aerospace.

You also pass down to future generations what's most important to you: your passion for aviation and aerospace and your desire to give flight to the dreams of students.

Including Embry-Riddle in your will or trust is a powerful way to ensure that future generations of your Embry-Riddle family are at the forefront of the next great era in aviation and aerospace.

For more information about supporting your Embry-Riddle family with a planned gift, visit

$$
\text { givingto erau.edu }
$$




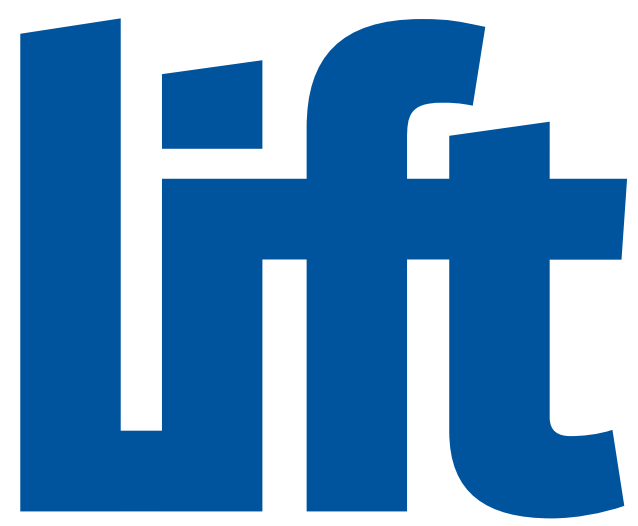

The alumni magazine of

Embry-Riddle Aeronautical University
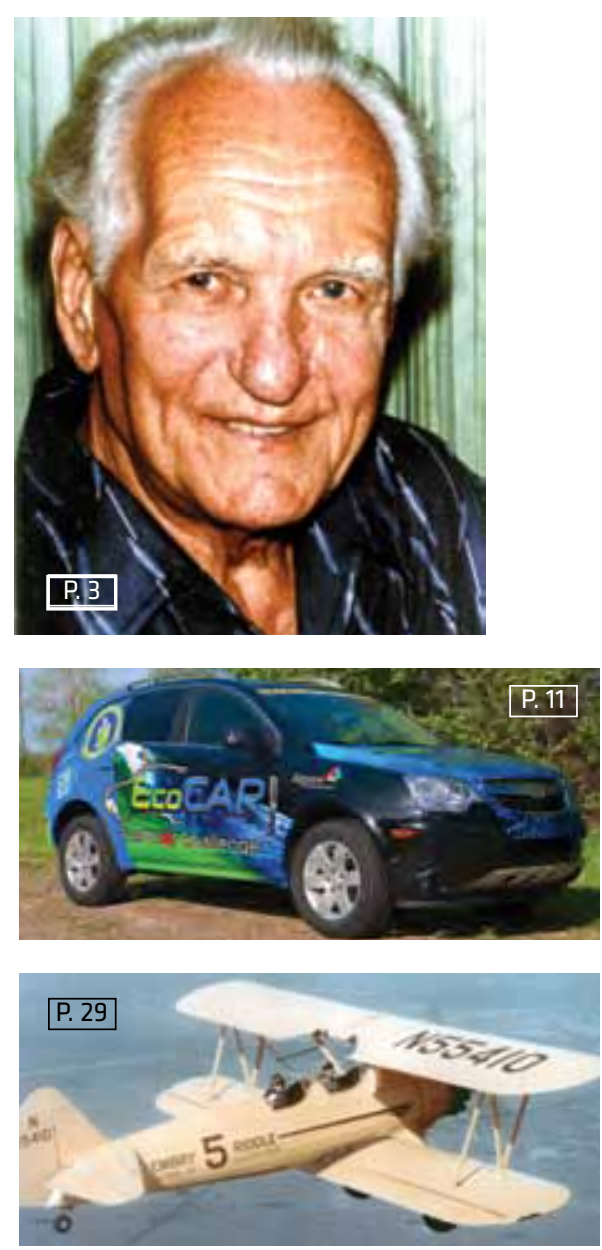

Lift: Special Report on Philanthropy is produced by Embry-Riddle's Office of Institutional Advancement.

Publisher: Dan Montplaisir, Vice President, Institutional Advancement

Editor: Anthony Brown, Director, Campaign Operations and Communications

Contributors: Ashlee (Fiser) IIg ('03, DB),

Communications Specialist

Maxine Sowinski, Coordinator, Donor Relations

\section{WINTER 2009}

\section{Special Philanthropy Report}

\section{PRESIDENT'S LETTER}

Success in the face of adversity

FISCAL YEAR 2009 FINANCIAL REPORT

\section{FARTHER AND FASTER}

The Emil Buehler Perpetual Trust's \$2 million gift to Embry-Riddle is the largest in the Trust's history

\section{RECOGNITION OF GIVING}

\section{GIFTS FUEL SUCCESS FOR ECOCAR STUDENTS}

EcoEagles are turning greenbacks into green solutions for the automotive industry

LOCKHEED MARTIN HELPS EXPAND ROBOTICS DEVELOPMENT AT ERAU PRESCOTT

Lockheed Martin donates \$10,0oo to expand robotics exploration

\section{DOWN TO EARTH}

Supporting the future of space by supporting students

\section{STUDENTS WHO MEAN BUSINESS}

The National Aircraft Finance Association and others contribute to student scholarships

\section{SCHOLARSHIPS SECURE A BRIGHT FUTURE}

A GRAND SLAM

Embry-Riddle Baseball program scores big with Sliwa family donation

FLIGHTS WITH FATHER INSPIRE GIFT FOR ASPIRING PILOTS

ENDOWMENT ACCOUNTS

TO SOAR CAMPAIGN RECAP

CONTACT INSTITUTIONAL ADVANCEMENT 


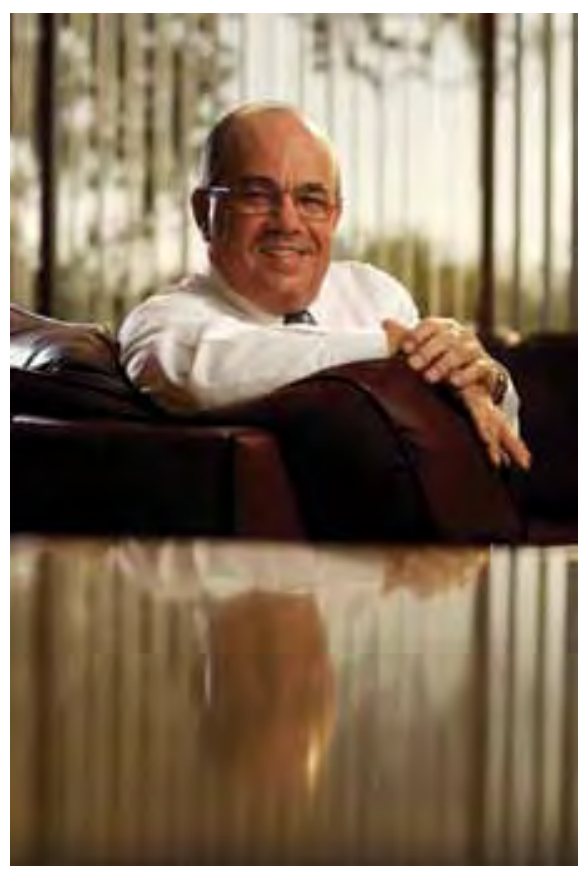

\section{Success in the face of adversity}

While Fiscal Year 2009 will likely be remembered as one shadowed by economic recession, Embry-Riddle will remember it as a strong year of investment in an exciting future.

Like most U.S. higher education institutions, we have felt the impact of the economic recession-but, thanks to some careful cost control measures and the generosity of our friends and alumni, we have also enjoyed one of our best fundraising years in recent history, raising nearly $\$ 7.7$ million in total gifts and pledges.

Success like this in the face of adversity speaks to the dedication and consistency of our alumni and friends who understand that in tough economic times, an investment in education is critical to sustainable recovery and long-term prosperity.

That is why we continue to move forward with cutting-edge facilities and new academic programs-like our first ever Ph.D. programs in Aviation and Engineering Physics. We believe that our investments in education are setting the stage for the next great era in aviation.

In this year's Special Report on Philanthropy, you will find stories of friends and alumni who clearly agree with our vision. From the Emil Buehler Perpetual Trust's support to help us build the most advanced aviation education complex in the country, to the high-tech company The MathWorks' investment in our award-winning engineering students, our donors see the critical role Embry-Riddle plays in the development of the aviation industry and its future workforce.

I would like to thank all who are listed in these pages for their continued generosity in these challenging times and their vision for and investment in Embry-Riddle's exciting future.

Warmest regards,

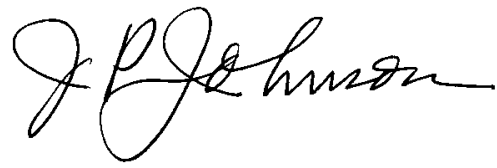

John P. Johnson, Ph.D.

President 


\section{Fiscal Year 2009 Total Giving $\$ 7,681,738$}

In a year marked by economic downturn, Embry-Riddle enjoyed its second-best fundraising year in the last five years, with gifts and pledges totaling nearly \$7.7 million.

Highlights this year include dramatic increases in:

Support from foundations and corporations. With leading gifts from the Emil Buehler Perpetual Trust and The Mathworks, Embry-Riddle raised more than \$5.7 million-compared to $\$ 837,323$ in the previous year.

Support for cutting-edge facilities and equipment. With $\$ 5.3$ million dedicated to help fund construction of the new James Hagedorn Aviation Complex and provide software for engineering students competing in the EcoCAR Challenge, Embry-Riddle is creating a win-win environment for students and industry.

Cash and equivalents and new pledges. From \$2.5 million the previous year, to $\$ 4.3$ million in FY 2009, EmbryRiddle and its students are benefiting directly from more immediate "cash in the door."

On the following pages are the stories and names of those who have kept Embry-Riddle strong during these challenging economic times. Their continued support will ensure that Embry-Riddle is well positioned to build on its great progress and remain a leader in aviation and aerospace education for years to come.

\section{Philanthropy by Purpose}

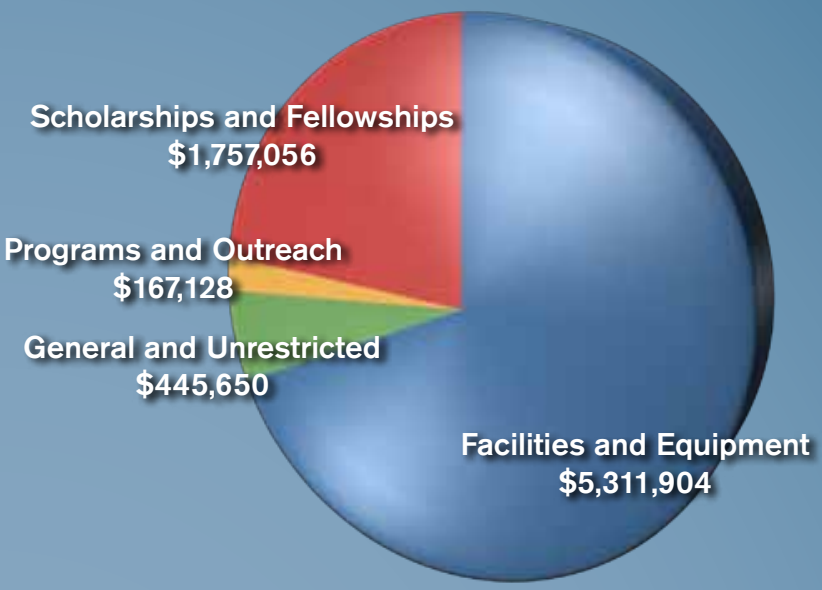

Philanthropy by Source
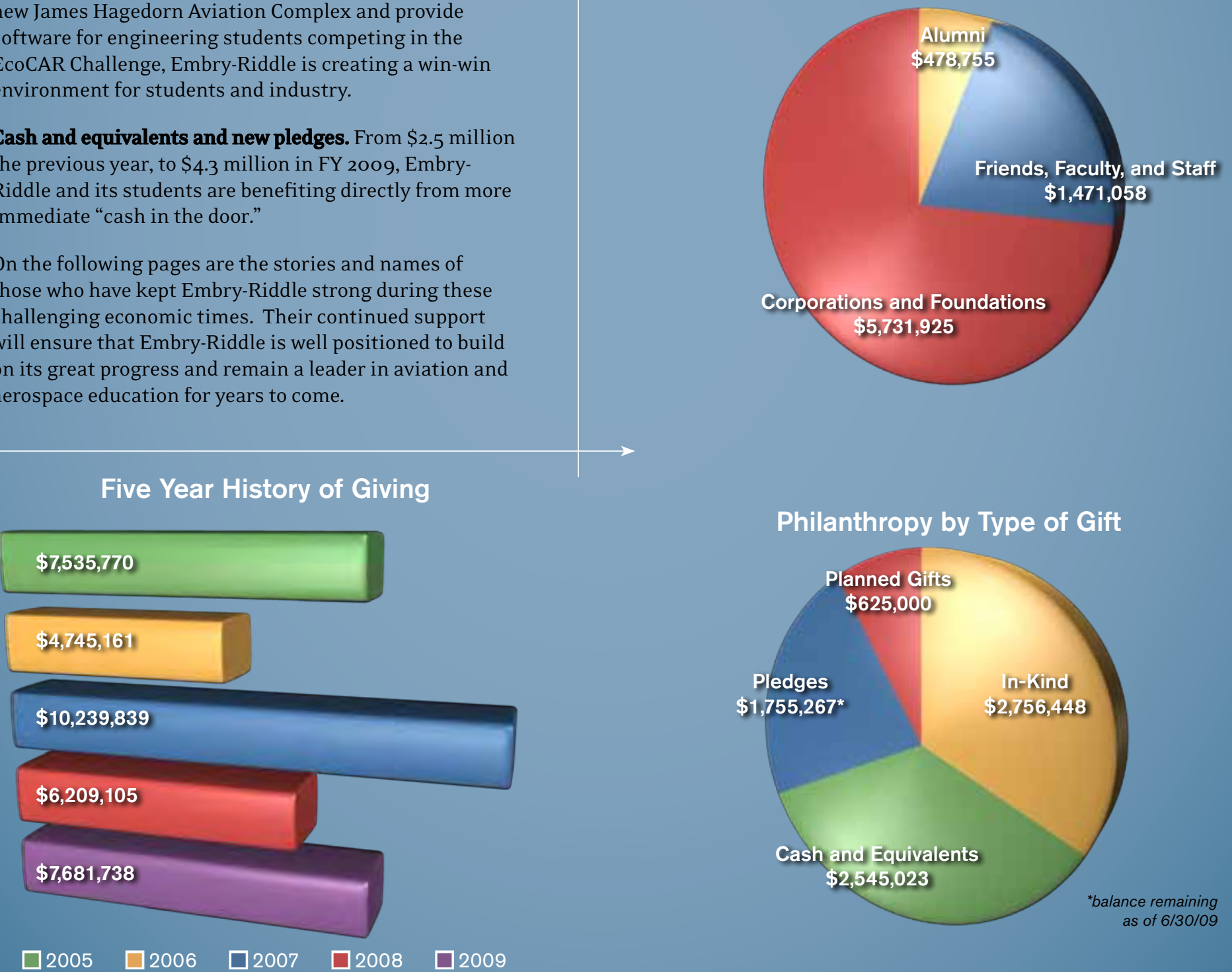

Philanthropy by Type of Gift

Five Year History of Giving

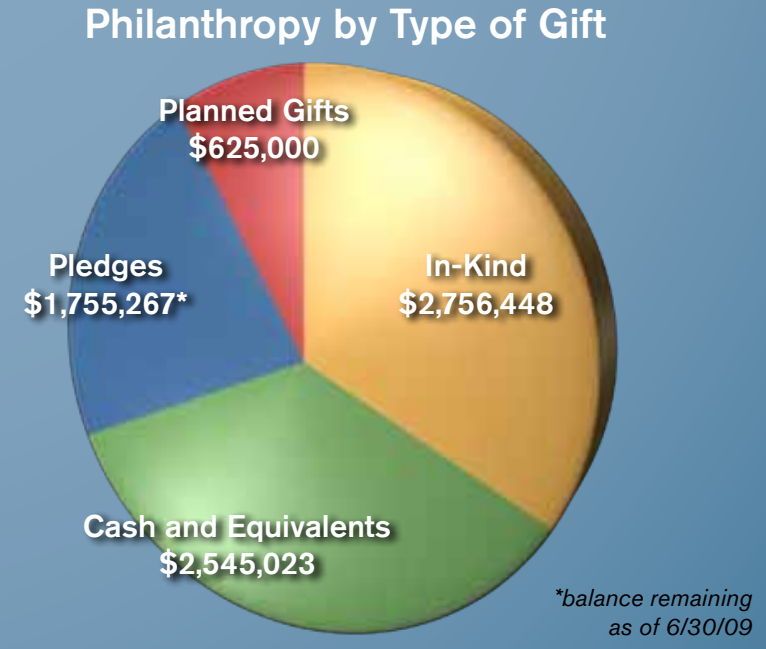



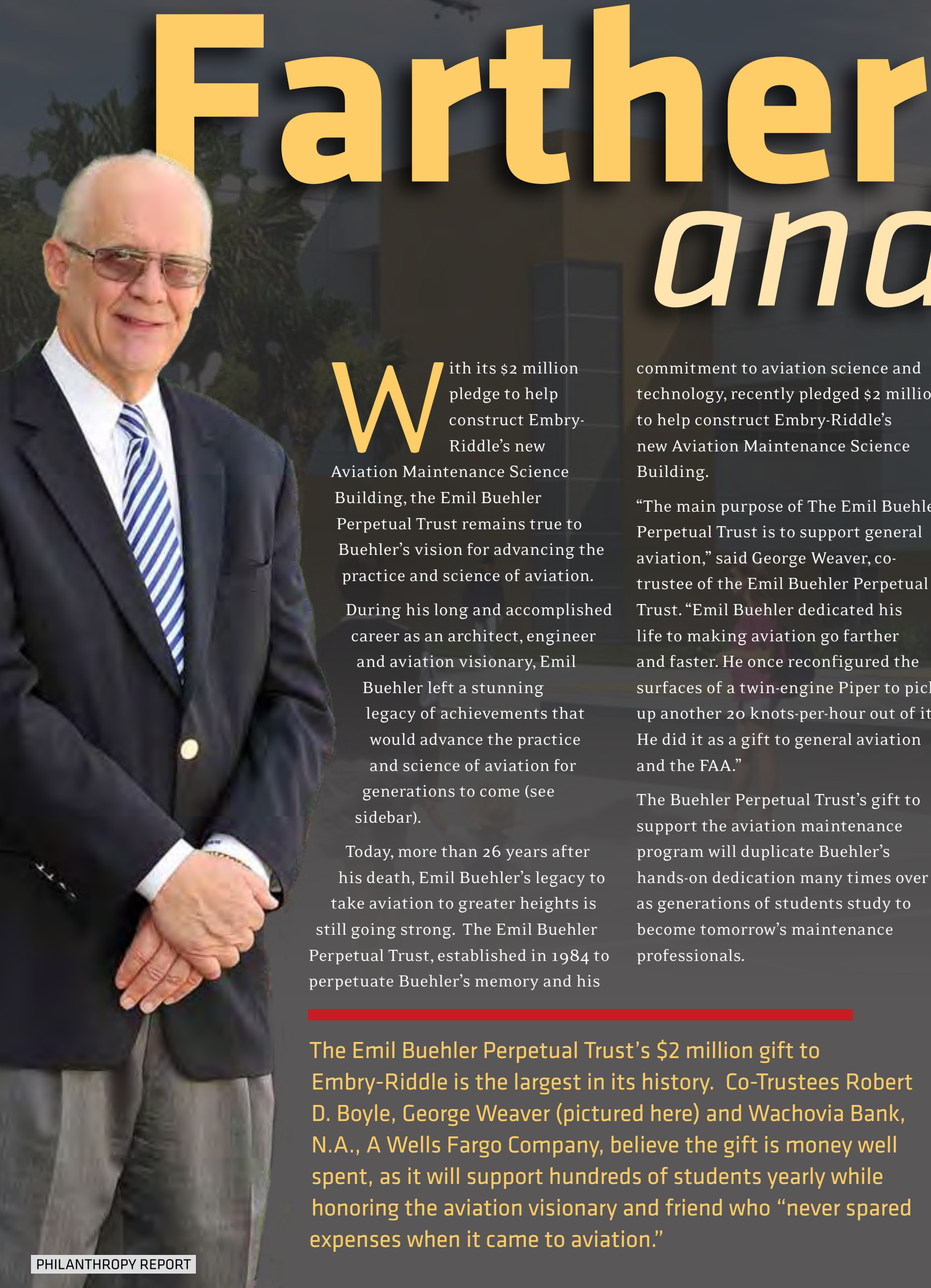

W

ith its $\$ 2$ million pledge to help construct EmbryRiddle's new

Aviation Maintenance Science Building, the Emil Buehler Perpetual Trust remains true to Buehler's vision for advancing the practice and science of aviation.

During his long and accomplished career as an architect, engineer and aviation visionary, Emil Buehler left a stunning legacy of achievements that would advance the practice and science of aviation for generations to come (see sidebar).

Today, more than 26 years after his death, Emil Buehler's legacy to take aviation to greater heights is still going strong. The Emil Buehler Perpetual Trust, established in 1984 to perpetuate Buehler's memory and his
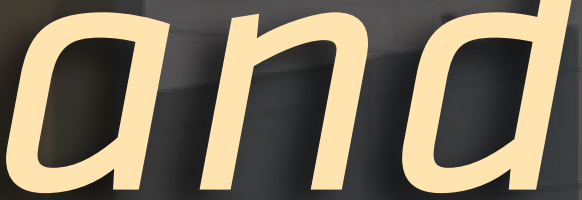

commitment to aviation science and technology, recently pledged $\$ 2$ million to help construct Embry-Riddle's new Aviation Maintenance Science Building.

"The main purpose of The Emil Buehler Perpetual Trust is to support general aviation," said George Weaver, cotrustee of the Emil Buehler Perpetual Trust. "Emil Buehler dedicated his life to making aviation go farther and faster. He once reconfigured the surfaces of a twin-engine Piper to pick up another 20 knots-per-hour out of it. He did it as a gift to general aviation and the FAA."

The Buehler Perpetual Trust's gift to support the aviation maintenance program will duplicate Buehler's hands-on dedication many times over as generations of students study to become tomorrow's maintenance professionals.

The Emil Buehler Perpetual Trust's \$2 million gift to Embry-Riddle is the largest in its history. Co-Trustees Robert D. Boyle, George Weaver (pictured here) and Wachovia Bank, N.A., A Wells Fargo Company, believe the gift is money well spent, as it will support hundreds of students yearly while honoring the aviation visionary and friend who "never spared expenses when it came to aviation."

\section{BACK TO CONTENTS}



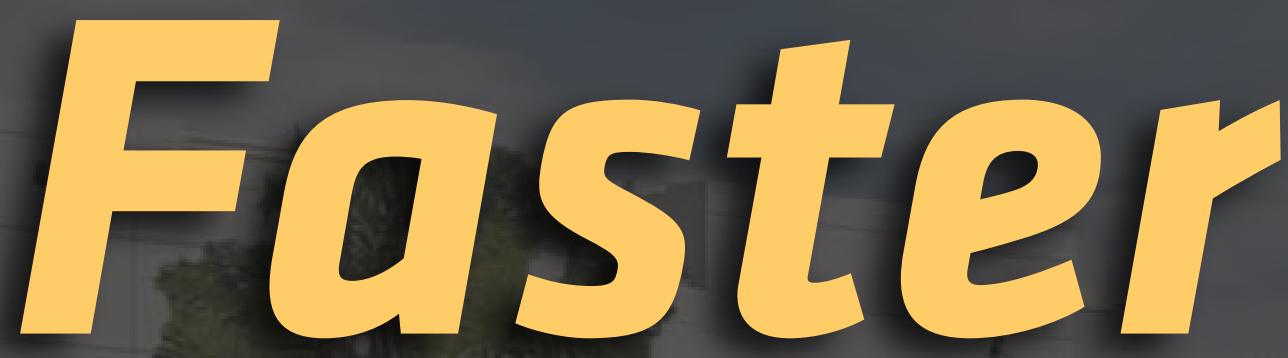

Located in the James Hagedorn Aviation Complex, the Emil Buehler Aviation Maintenance Science Building will house a series of cutting-edge labs dedicated to aircraft systems, turbine engines, metallic and composite materials, avionics and avionics electronics. The 46,000 square-foot facility will also include classrooms, a licensed engine repair station, a machine shop, offices, and an observation deck located on the third floor that will support university and student functions.

The Emil Buehler Perpetual Trust's \$2 million pledge represents almost one-half of the $\$ 4.5$ million in private contributions committed to Phase II of the James Hagedorn Aviation Complex, which will also include a new flight maintenance hangar and flight operations center to be built concurrently with the Emil Buehler Aviation Maintenance Science Building.

"Thanks to the generosity and vision of the Buehler Trust, Embry-Riddle will continue to provide students with the best aviation-related training and technology available anywhere," said Embry-Riddle President John P. Johnson.

For Weaver, the gift is an opportunity to expand Buehler's legacy to ever-greater numbers of aviation professionals. "When we considered the stewardship of Buehler's legacy, we chose to give to Embry-Riddle because it was a way to maximize the positive impact on aviation. Giving money to Embry-Riddle benefits a lot of people in aviation."

From 1984 to date, the Emil Buehler Perpetual Trust has given more than \$30 million to various charitable entities in the fields of aviation, science and technology.

Embry-Riddle would like to thank the following Trustees of the Buehler Perpetual Trust for the generous contribution to support aviation education:

Robert D. Boyle, CPA

George Weaver

Wachovia Bank, N.A., A Wells Fargo Company

Emil Buehler's many

contributions to

Aviation Science and Technology

Although he spent most of his career as a renowned architect and engineer, Emil Buehler (pictured below) often incorporated his love of aviation, both directly and indirectly, into his life's work. Here are just a few highlights of Emil Buehler's contributions to aviation science and technology:

- He operated his own school of aeronautics at New Jersey's Teterboro Airport and ran a seaplane base on the Hudson River.

- He supervised the construction of an aviation facility at the Executive Airport in Ft. Lauderdale.

- He funded the development of a wind tunnel with Mach 3 capability, allowing the testing of space vehicles in design configurations at speeds up to three times the speed of sound.

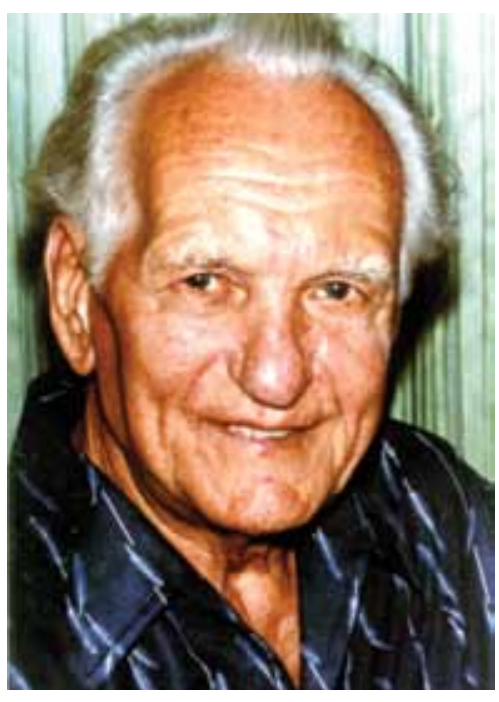




\section{Leadership Gift Societies}

Through their support and enthusiasm for our mission, members of our Leadership Gift Societies not only help us maintain the educational programs and the physical components of Embry-Riddle's campuses-the desks, the library books, the training technology-but also the intangible qualities of a leading university: the sense of community, the respect for tradition, and the recognition of achievement.

To recognize the generosity of these donors, Embry-Riddle has established these Leadership Gift Societies:

\section{The Jack R. Hunt Society}

Named for Embry-Riddle's first president, the Jack R. Hunt Society honors donors whose lifetime giving to the University totals \$1 million or more.

\section{The John Paul Riddle Society}

Honoring a founder of the University, the John Paul Riddle Society recognizes donors who make lifetime contributions totaling at least \$500,000.

\section{The T. Higbee Embry Society}

Named for John Paul Riddle's entrepreneurial partner, the T. Higbee Embry Society recognizes donors with lifetime contributions of \$100,000.

\section{The Legacy Society}

Recognizing donors who include Embry-Riddle in their estate, the Legacy Society supports multiple generations of aeronautical leaders.

Every effort has been made to ensure the accuracy of these lists. Please accept our apologies for any inadvertent errors or omissions. Please call Maxine Sowinski, donor relations coordinator, at (386)226-6138 or send an e-mail to maxine.sowinski@erau.edu with your changes, corrections, or questions.

\section{Jack R. Hunt Society}

\section{Corporations and Foundations}

Airbus Services Company

Boeing Company Charitable Trust

Boston Scientific

Emil Buehler Perpetual Trust

Honeywell

Intervest Construction

The Mathworks

Rolls-Royce Corporation

\section{Alumni and Friends}

Jay and Leila Adams

Michele Bowman-Underwood and

Joseph Underwood

James and Beverly Cone

Samuel Goldman

James ('79, DB) and Karli Hagedorn

Mori ('79, '82, DB) and Forough ('85, DB) Hosseini

Roger Koch

L. Gale Lemerand

Dorothee Miller

S. Harry and Linda Robertson

Steven and Christine Udvar-Hazy

\author{
John Paul Riddle Society \\ Corporations and Foundations \\ Air Force Association \\ Analytical Graphics \\ Boeing Company \\ Edyth Bush Charitable Foundation \\ Constellation Productions \\ Frasca International \\ Robertson Research Group \\ Gen. William W. Spruance Foundation \\ The Wessel Foundation
}

\section{Alumni and Friends}

James and Essie Barfield

Tine and Eunice Davis

Andrew Deas ('6o, WW)

Estate of William Haas

Constance Hunter

Edward and Carolyn King

William March ('81, WW)

William Pitts ('6o, MC)

William and Eunice Spruance

Helen Wessel

\author{
T. Higbee Embry Society \\ Corporations and Foundations \\ AAR Corporation \\ Aircraft Owners \& Pilots Association \\ AlliedSignal Air Transport Avionics \\ American Airlines \\ Associated Aviation Underwriters \\ Aviall \\ Brown \& Brown of Florida \\ Cessna Foundation \\ Cobb, Cole and Bell PA \\ Computer Presentations and Training \\ Consolidated-Tomoka Land Co. \\ Dade Community Foundation \\ Tine W. Davis Family Foundation \\ Daytona Aerospace Industrial Park Joint Venture \\ Delta Air Lines \\ DS SolidWorks Corp. \\ Equis Financial Group LP \\ Florida Independent College Fund \\ Follett Higher Education Group \\ Gulfstream Aerospace Corporation \\ Halifax Paving \\ Honeywell International Foundation
}




\section{T. Higbee Embry Society (cont.)}

Honeywell

Paul B. Hunter and Constance D. Hunter Charitable Foundation

International Order Of Characters

International Speedway Corp.

ISTAT Foundation

Kresge Foundation

Bill \& Moya Lear Charitable Foundation

Link Foundation

Marmot Foundation

Mead Witter Foundation

Mission Air Support

Amelia Peabody Charitable Fund

Professional Food Service Management

The Robertson Foundation

Rockwell Collins

The Albert L. Ueltschi Foundation

United Technologies Corporation

US Airways

The Wachovia Foundation

\section{Alumni and Friends}

George and Patricia Adam

Robert and Carol Allen

Estate of Virginia T. Bingham

Lawrence and Barbara Clarkson

Elizabeth Coley and William Smith

Victor and Betsy Cresenzo

De Rhoads Dolan

Linda Downs

Philip and Joyce Elliott

William and Betty France

Rudy and Lucille Frasca

George Gallaspy

William Haas

Jim and Carole Henderson

Louis and Dava Hoffman

Russell Holderman

Daniel and Diane Izard

Sharon Jones ('84, PC)

Moya Lear

George Lerman

Joseph ('74, DB) and Catherine Martin

Joseph and Joan McClure

Robert and Emily McKay

George Mendonca

D. Keith ('95, '97, WW) and Alice Mosing

James and Janet O'Connor

William and Dixie O'Connor

Quentin and Jeani Pearson

David and Andrea Robertson

Nancy Robertson

James Robinson

David and Yolande Salter
Raymond and Frances Sigafoos

Al Skeaney

David and Toni Slick

Steven and Nancy Sliwa

Richard Snyder

Lee Spence

Thomas and Barbara Staed

Edward and Dorothy Stimpson

Estate of Druria L. Sylvester

Maurice and Dorothy Taylor

Albert Ueltschi

Lawrence and Virginia Vagnozzi

Charles Vouaux

Alexander and Mary Wells

Dudley ('42, MC) and Phyllis Whitman

R. Lyman and Meredith Wood

Gertrude Worthington

\section{Legacy Society}

Jay and Leila Adams

Matthew Andersson ('96, DB)

Patricia Arntzen

Robert and Mary Beilman

Robert ('71, DB) and Judy Belinke

Catherine Benson

Margaret ('84, PC) and Thomas Billson

Stephen ('86, PC) and Terri Blanchette

Gerald Bott

Michele Bowman-Underwood and

Joseph Underwood

The Robert and Lois Braddock Foundation

Benjamin ('82, DB) and Signe Canfield

Allen Colfry ('66, DB)

James and Beverly Cone

Robert and Jennifer Crouch

David and Marguerite Cummock

Gary and Else Cunningham

Jody Doeden ('91, PC; 'o5 WW)

De Rhoads Dolan

George Errick

Charles and Karen Ford

James ('92, '95, DB) and Suellen Gallogly

Samuel Goldman

David and Nancy Gonnion

Nancy Graham

William Haas

I.V. and Loma Hamilton

George ('78, WW) and June Hill

Louis and Dava Hoffman

Constance Hunter

John Hurley

Charles and Marion Johnson

Sharon Jones ('84, PC)

Ronald and Carloyn Kerlin

Roger Koch
James Kolbe

Kenneth and Mary Lamalie

L. Gale Lemerand

Dennis and Deborah Lessard

Robert and Virginia Lyall

William March

George and Karen McCown

Robert and Emily McKay

Roy and Mary Miller

Daniel E. Montplaisir

D. Keith ('95, '97, WW) and Alice Mosing

William and Dixie O'Connor

John and Ann Olsen

Robert Oxley

Nancy ('74, DB) Pettit

William Pitts ('6o, MC)

Deborah Lee Prescott

Walter Prettyman ('75, DB)

Charles and Joan Richardson

Fred ('68, DB) and Julie Robinson

Robert Rockett

Nancy Shiver-Foret

Raymond and Frances Sigafoos

Mary Spence

Raymond ('75, DB) and Wendy Springsteen

William and Eunice Spruance

Thomas and Barbara Staed

Betty Stern

Edward and Dorothy Stimpson

James and Marilyn Subach

Maurice and Dorothy Taylor

Dianne (81, DB) and Raymond Thompson

Charles Vouaux

Alexander and Mary Wells

Fred and Alice Wills

Kevin Wisneski ('98, DB)

Phillip Woodruff ('71, DB)

James Zeiler ('8o, DB) 


\section{Annual Gfft Societies and Clubs}

Embry-Riddle's annual gift societies and clubs recognize the generosity of those donors whose annual financial support demonstrates their dedication to the future of aviation and aerospace education.

\section{The Eagle Society}

The Eagle Society was established in 1986 to support academic programs and student opportunities in all areas. Today, the dollars donors invest not only enhance general programs and operations but furnish scholarship funds for deserving students and help the university acquire state-of-the-art technology and library resources.

To recognize the commitment of these donors, the Eagle Society has established four gift societies:

\section{Platinum Eagles}

Through gifts of \$10,ooo or more each year, Platinum Eagles help shape the future of Embry-Riddle Aeronautical University.

\section{Gold Eagles}

By making annual gifts of $\$ 5$, ooo or more, Gold Eagles secure Embry-Riddle's position as an outstanding institution of higher education.

\section{Silver Eagles}

Through annual support of $\$ 2,500$ or more, Silver Eagles build the unsurpassed training programs that have become a hallmark of our university.

\section{Bronze Eagles}

Through annual support of at least \$1,ooo, Bronze Eagles help us soar to new heights in educational achievement.

\section{Annual Fund Gift Clubs}

Our Annual Fund gift clubs recognize and honor individuals who contribute up to \$999 a year. Levels of membership are:

Squadron 500-Annual gifts totaling \$500 to \$999 Squadron 10o-Annual gifts totaling \$10o to \$249

Squadron 250-Annual gifts totaling \$250 to \$499 Cadet-Annual gifts totaling less than \$10o

Every effort has been made to ensure the accuracy of these lists. Please accept our apologies for any inadvertent errors or omissions. Please call Maxine Sowinski, donor relations coordinator, at (386)226-6138 or send an e-mail to maxine.sowinski@erau.edu with your changes, corrections, or questions.

\section{Platinum Eagles}

\section{Corporations and Foundations}

Air Force Association

Aircraft Owners \& Pilots Association

Aircraft Technical Publishers

American Pacific Corporation

Boeing Company Charitable Trust

Brown \& Brown of Florida

Emil Buehler Perpetual Trust

Cessna Foundation

Dade Community Foundation

DS SolidWorks Corp.

Frasca International

Honda Research Institute USA

Paul B. Hunter and Constance D. Hunter

Charitable Foundation

International Order of Characters

Intervest Construction

Lightspeed Aviation

Lockheed Martin Corporation
The MathWorks

NVIDIA Corporation

Pinnacle Aircraft Parts

Gen. William W. Spruance Foundation

TBM Owners and Pilots Association

Tecnam Aircraft

The Wessel Foundation

WFF Facilty Services

The Wings Club

Alumni and Friends
John ('73, DB) and Donna Amore
Charles Carll
Michael ('76, DB) and Pamela DeGiglio
Linda Downs
Kenneth ('89, WW) and Antoinette Dufour
James Fiala
Tracy Forrest
Rudy and Lucille Frasca
David Gordon ('8o, DB)

James ('79, DB) and Karli Hagedorn

Jim and Carole Henderson

Mori ('79, '82, DB) and Forough ('85, DB) Hosseini

Constance Hunter

D. Keith ('95, '97, WW) and Alice Mosing

Geoffrey ('87, DB) and Lisa Murray

Deborah Lee Prescott

David and Andrea Robertson

S. Harry and Linda Robertson

Louis and Christine Seno

David and Antoinette Slick

Steven and Nancy Sliwa

Richard Snyder

William and Eunice Spruance

Estate of Druria L. Sylvester

Estate of Maurice F. and Dorothy D. Taylor

Steven and Christine Udvar-Hazy

George Weaver

Helen Wessel 


\section{$\longleftarrow$ R E C O G N I T I O N O F G I V I N G}

\section{Gold Eagles}

Corporations and Foundations

ACSS

The Robert and Lois Braddock

Charitable Foundation

Command Medical Products

Daytona International Speedway

Florida Independent College Fund

GE Capital Solutions

Marmot Foundation

JR Martin and Company

Oliver Wyman

Staed Family Associates

United Space Alliance Foundation

\section{Alumni and Friends}

Jay and Leila Adams

Robert and Lois Braddock

Lawrence and Barbara Clarkson

Blaine and Brian Lansberry

Joseph ('74, DB) and Catherine Martin

George Mendonca

James and Janet O'Connor

Gordon and Celia Ritter

Estate of Wesley Segner

Thomas and Barbara Staed

Robert and Suzanne Windham

\section{Silver Eagles}

\section{Corporations and Foundations}

Air-Sur

American Volunteer Group

Amerisport International

Blackhawk Flight Foundation

Chartwells

CIT Group

Florida Aviation Trades Association

Florida Power \& Light

Halifax Health

Hilton Garden Inn Daytona Beach

Huntzberry \& Son

J. W. Kieckhefer Foundation

Rockwell Collins

Wal-Mart Foundation

\section{Alumni and Friends}

Thomas Anderson

Steve and Diane Andrade

Patricia Arntzen

Richard Bloom

Thomas Coughlin ('75, WW)

Robert and Jennifer Crouch

Damon ('94, DB) and Debra D'Agostino

Bernadine and Garth Douglas

Thomas and Ann Hilburn

Ronald and Sharon Huntzberry

Alvin ('go, DB) and Juleen Jackson

John and Maurie Johnson

James and Karen Muff

Michael and Linda Piscatella

Nancy Ryba

Thomas and Doris Sieland
Linda Titus

Jerry and Carole Vanier

William and M. Susan Voges

John and Teresa Wing

\section{Bronze Eagles}

\section{Corporations and Foundations}

Aero Design Services

AirTran Airways

Braniff Silver Eagles Charitable Fund

Bright House Networks LLC

Cessna Aircraft Company

Tom Davis Fund

East Central Branch A.S.C.E.

Ercoupe Owners Club

Felix Air

Giles Electric Company

Halifax Paving

Hobbico

LPGA International Girls Golf Club

LTP

Jenna Menard at Exclusive Artists

Pattman Plumbing, Heating and Air Conditioning

The Dr. P. Phillips Foundation

Premier Jet Aviation

Prescott Area Arts \& Humanities Council

Radiology Associates Imaging Centers

Rand Sports \& Entertainment Insurance

Root Company

Schlossberg \& Associates

Sodexho Dining Services

Sodexo \& Affiliates

Stonewood Grill \& Tavern

Tampa Bay Buccaneers

A.M. Weigel Construction

Yes We Can! Foundation

\section{Alumni and Friends}

Eleanor and Paul Baum

Steven and Brenda Bobinsky

George ('o3, WW) and Debbie Bowen

James Boyce

Tim and Mary Brady

Robert and Jean Bricker

Charles and Kathleen Burch

Steve and Fran Chadwick

Matt Chapman

James and Beverly Cone

Terry ('87, WW) and Terri Cox

Paul and Pam Crampton

Victor and Betsy Cresenzo

Steven and Karen DeGeorge

De Rhoads Dolan

Barbara Dovi

Leonard Durrance

Lance Erickson

Jeffrey and Lori Feasel

Richard and Gloria Felton

John and Kelly Ferguson

Randall Fiorenza ('86, '9o, DB)

Richard Foote ('86, DB)

John ('72, DB) and Carol Foster
Fred Gibson

Bradley and Leigh Giles

W. Dean Glasser

William ('87, WW) and Nuala Glennon

Robert Goldberg

Erin Gormley ('97, PC; '05, WW)

David and Teresa Hall

John Hamilton

Kevin and Maria Hayworth

Karen and James Holbrook

Timothy Hollenshade Jr. ('o7, DB)

Timothy and Debra Hollenshade

L. Evans and Linda Hubbard

John and Judy Jenkins

Daniel ('o4, WW) and Margaret Johnson

Salvatore and Jan Jordano

Karl ('9o, '94, WW) and Karin Kaufman

Robert Kelm ('96, PC)

Roger Kinnard

Harry and Ada Lamon

Kathy Lewis

John ('81, DB) and Judith Longshore

Maria Lopez

Jenna Menard

Agatha Miconi

Dorothee Miller

Michael and Kathryn Milthorpe

Daniel and Kelly Montplaisir

James and Kristen Mooers

Janet Muff

Thomas Nissley and Emily McKay

Steven ('9o, DB) and Elizabeth ('94, DB) Nordlund

John and Ann Olsen

Tae and Soo Oum

John Pattman

Donald and Jean Popp

Donald and Anne Rabern

John Rand

William Rathmanner ('8o, DB)

Christina and Anthony Recascino

Stacey Reynolds-Carruth and Robert Carruth

George and Gay Rice

Steven and Vicky Ridder

John ('73, DB) and Uta Rollins

Roger Schlossberg

William Schoknecht

Roland Shaw ('95, WW)

Martin and Judith Smith

Thomas ('93, DB) and Lisa Snyder

William and Betty Steele

Joseph Szarmach ('91, DB)

Charles Vuille and Dianne Kowing

Gregory and Christie Warmoth

Eric and Marcia Weekes

A. Michael Weigel

Stanley and Mary Williams

Timothy Wilson

\section{Squadron $\mathbf{5 0 0}$}

Corporations and Foundations

Airport Centre Properties LLC

Associated Dermatologists 


\section{$\longleftarrow$ R E C O G N I T I O N O F G I V I N G $\longrightarrow$}

BluewaterPress LLC

Cobb \& Cole

Tom Cook Jeweler

Corban College

Courtyard by Marriott

Dassault Falcon Jet Corp.

Daytona Limos

Daytona State College

Deloitte

DS Technologies LLC

Elite Hospitality

Ercoupe Owners Club

Florida Bar Aviation Law Committee

Florida Hospital Ormond Memorial

Ginn Hammock Beach Resort

The Glinzman Family Revocable Trust

Gulfstream Int'l Airlines

Halifax Youth Sailing

Hayworth Creative

Kadrmas Chiropractic PC

Kelley/Wise Engineering

Marriott International

Motorsports Charities

NASCAR

New Smyrna Chevrolet

Odyssey Travel

Captain James Ormond D.A.R.

$P \& S$ Paving

Parks Dermatology Center

Plantation Bay Golf \& Country Club

$\mathrm{R} \& \mathrm{R}$ Industries

Bruce Rossmeyer's Daytona Harley-Davidson

Southeast Automotive Management

Law Office of Jerry H. Trachtman PA

Upchurch Watson White \& Max

Weckworth Electric Company

Myles and Kimberly Wilkinson Charitable Fund

\section{Alumni and Friends}

James Adams and Barbara Fidel Adams Jeffrey Allen

Sharon and Kenny Amick

Robert ('51, WW) and Luann Anderson

Eric ('82, DB) and Kelly Asplundh

Glenn Barcheski ('88, DB; 'o5, MC)

Nancy Barrett

Michael and Rebecca Becker

Barbikay Bissell Pohl

Jeffery Bloom ('88, PC)

Howard ('8o, DB) and Susan Blower

Edward ('79, DB) and Sandra Breslin

Richard and Anne Brown

Maurice and Johanna Brutinel

John and Elisabeth Bussard

John and Andrina Carey

Richard and Ann Collins

James and Cheryl ('96, DB) Cunningham

Edward ('85, DB) and Jamie Deeds

Laurie ('82, DB) and James DeGarmo

Will and Kathryn Degroat

John and Carol Doctor

S. Ray ('59, MC) and Helen Ellington
Andrew and Rita ('95, PC) Ferencak

E. Allen Fidel

June Fidel

Mary Fletcher Forstall

David Fletcher

I had a great experience during my time at the Prescott campus. I think much of the environment that made my experience so positive was due to the hard work of the faculty, staff and the contributions of university supporters. Although I no longer live near a residential campus, Embry-Riddle will always be part of my community, and I will continue to give when and in ways that I can.

\section{Whether giving personally or} corporately, the most rewarding giving experiences come when the gift is received with gratitude and appreciation. That was exactly the case when Lightspeed donated headsets to the camp programs in Prescott and Daytona Beach. The staff we worked with was professional and genuinely thankful for the support. It makes you want to keep giving.

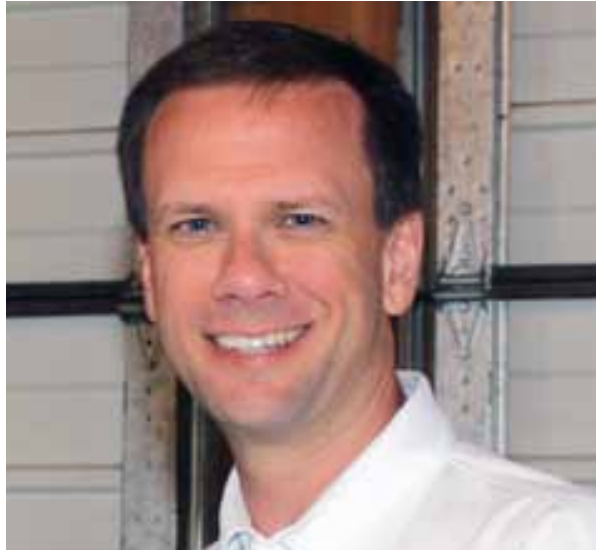

David Custafson ('90, PC), Strategic Accounts Manager at Lightspeed Aviation, on his company's donation of Zulu headsets to Embry-Riddle's aviation outreach summer camps held on its residential campuses.

Martin Ford

Andrew and Cynthia Fraher

Lesa France Kennedy

Rolf Franke
Sharon Giles

Tammy-Renee Giroux

Lawrence Glinzman

Stephen and Myra Gons

William and Anne Grams

Thomas and Jolene Guinn

Kim Habermann ('78, DB)

Richard and Carolyn Hauver

Thomas Hay

Michael and Lynda Helton

Michael Hickey

Cheryl ('92, PC) and James Hodge

Jack Holcomb

Christine ('82, '89, DB) and Garrett ('87, DB) Ison

Patrick Kadrmas

Peter and Eva Kaus

Gary Kelley

Jerry and Killian Kidrick

Paul and Paula King

Richard ('95, WW) and Charlotte King

Vern Kuftik

Andrew Kurtz ('o6, DB)

Patrick Kuykendall

Ronald and Paulin Leacock

Morris ('85, DB) and Judy Little

Robert and Sandy Lloyd

Gerald ('89, DB) and Elizabeth Lohr

John Long

Margot Machol and Mark Bisnow

Reda and Amy Mankbadi

Linda Manning and Bradley Blair

Barbara and Carl Martens

Kenneth and Shirley Masser

Patrick ('86, DB) and Mary McCarthy

Daniel and Hae McCune

William and Linda McMunn

Robert and Beverly Morrison

Barbara and Marty Munderloh

Carlos Murphy

John ('68, WW) and Kathy O'Brien

John and Kathy Olivero

Robert Oxley

Daniel Petree

Martin and Ingrid Pohl

Joshua Powell ('99, DB)

Randolph and Vonna Reynolds

Don Roberts ('95, '97, WW)

Robert Rockett

Zane ('91, DB) and Mary Rowe

David and Yolande Salter

Jeremy Samuels

Louis and Judy Samuels

Neil and Linda Samuels

Eduardo Santos ('85, DB)

Randall Shaffer

Dana and Lynn Smith

Darrel and Debbie Smith

Craig ('oo, PC) and Sherri Steiner

John and Betsy Teaford

William ('87, PC) and Donna Thompson

Joseph Tinsley ('o4, DB)

John and Loretta Tolland 


\section{Gifts fuel success for EcoCAR}

\section{students}

Hard at work in their "Green Garage" working lab, members of the EcoCAR Challenge student team, known as the EcoEagles, are turning greenbacks into green solutions for the automotive industry, thanks to the financial support of Embry-Riddle friends and faculty.

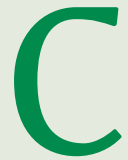

ompeting against 17 other collegiate teams in a three-year competition, Embry-Riddle's EcoEagles are re-engineering a 2009 Saturn Vue from start to finish to be more eco-friendly. So far, they are near the top of the pack, placing 4 th overall in a recent competition and earning a total of $\$ 18,250$ in awards - more than any other school in the competition.

"The EcoCAR project has given students both the knowledge and the motivation to go out and be agents of environmental change," says Dr. Darris White, associate professor of Mechanical Engineering and lead faculty advisor of the EcoCAR Challenge Team. "It is very exciting, and we could not be in this competition without the support of university friends."

Dr. White credits much of their success to the support of Board of Trustees member David Robertson and electrical engineering department chair Al Helfrick, both of whom have contributed to the Baja SAE, Formula SAE and Formula Hybrid student teams over the years. "They allowed us to build a track record with the student automotive projects," he explains. "We were able to leverage our prior successes in these competitions and academics to get into this [EcoCAR] competition."

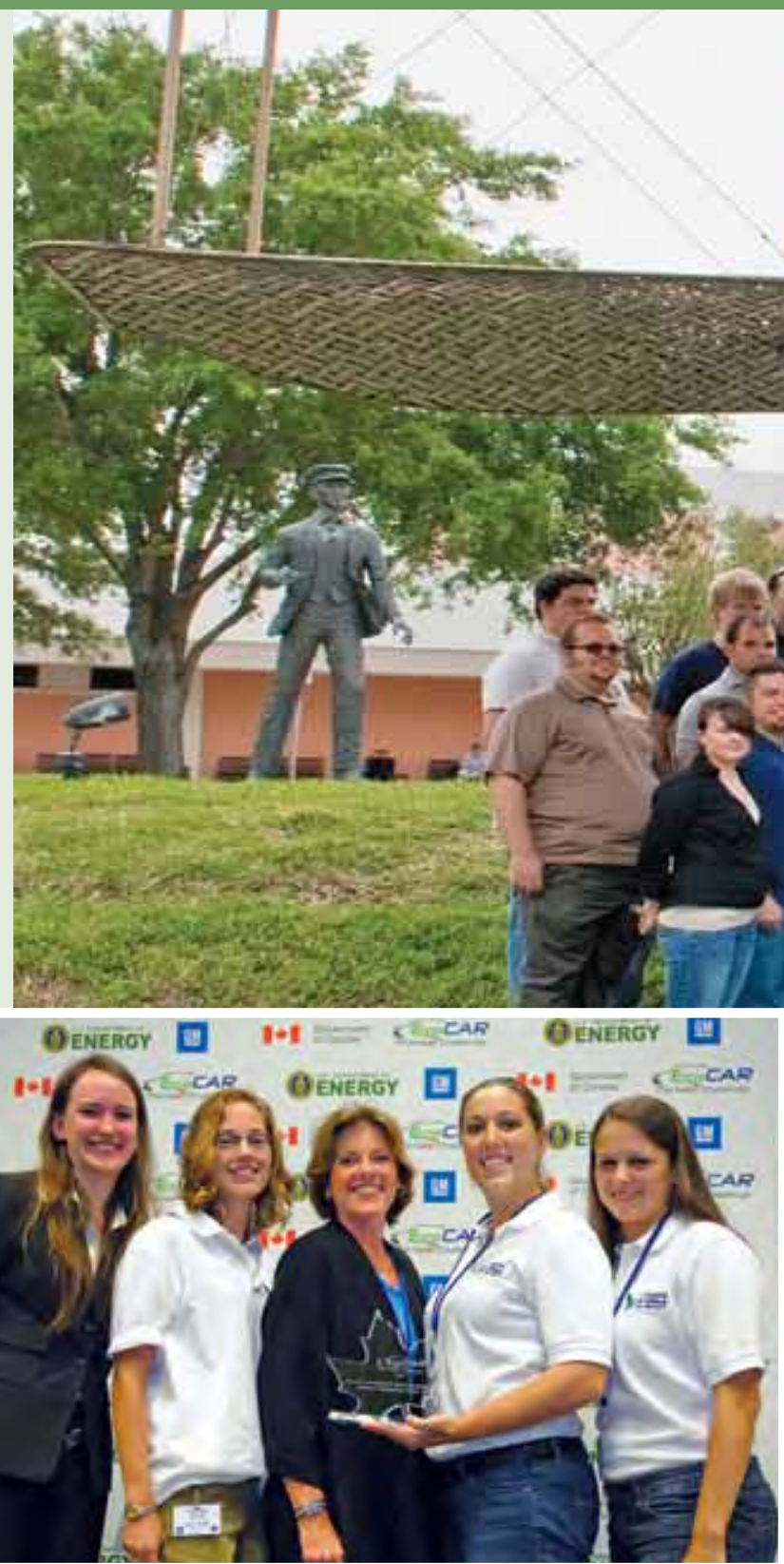

Lyn St. James, founder of the Women in the Winner's Circle Foundation (center), presents the EcoCAR Women in Engineering Award to Embry-Riddle engineering students (left to right): Jeanette Barott - EcoEagles Communications Specialist, Jennifer Haydt (Civil Engineering), Nicole Puchacz (Mechanical Engineering) and Nicole Lambiase (Mechanical Engineering).

Gifts from Robertson, Helfrick and others have done more than make competition in EcoCAR possible; they've helped the EcoEagles win awards-like most recently, the EcoCAR Women in Engineering Award.

Given by the Women in the Winner's Circle Foundation, the award honors female engineering students who demonstrate outstanding technical excellence in the EcoCAR competition. 


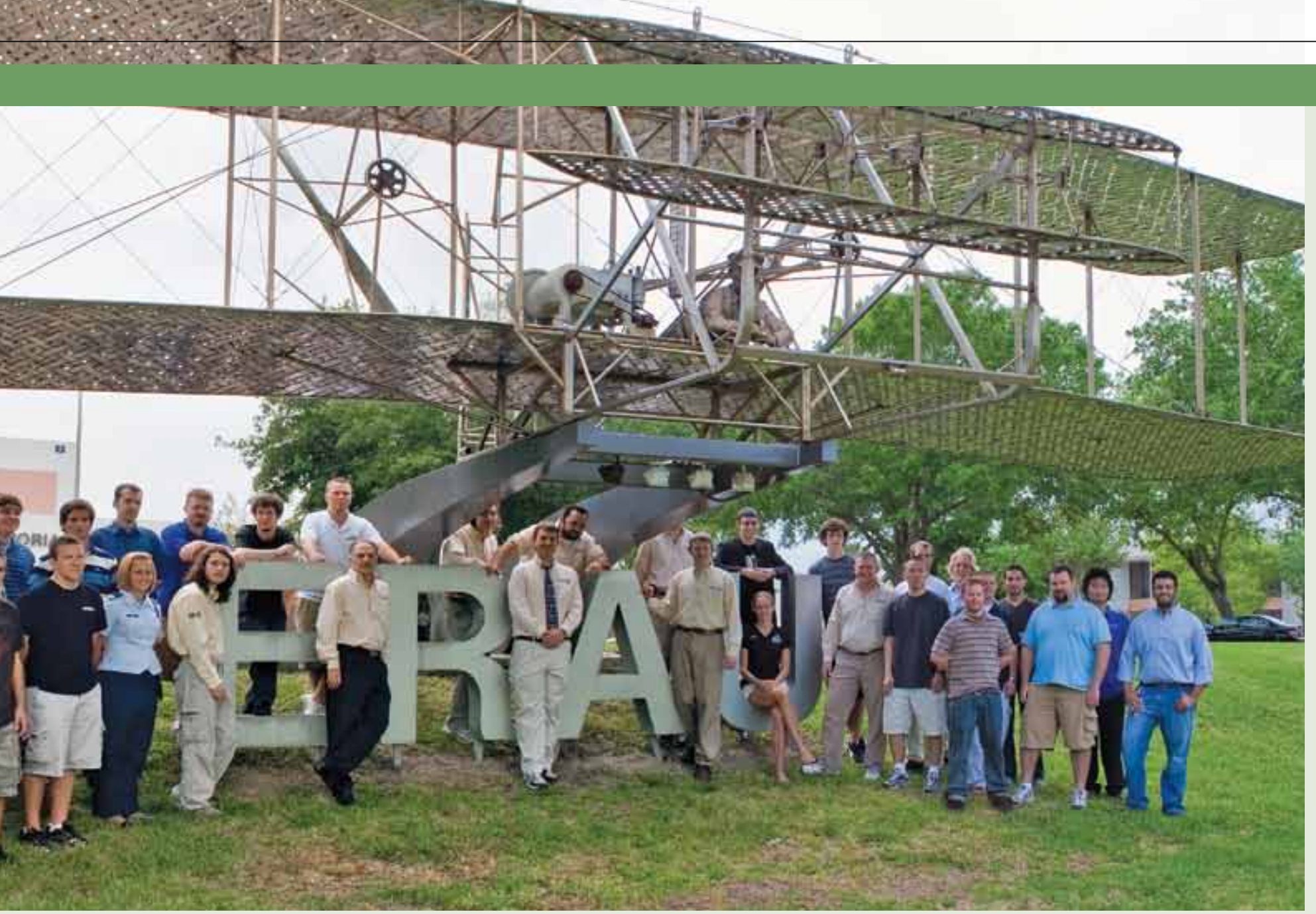

In addition to support from university friends, the EcoEagles received a \$2.8 million gift-in-kind from The MathWorks, a sponsoring software company that provided technologies for the students to create detailed dynamics and controls models of every component of their vehicle.

"The MathWorks gift was vital to our success this year," Dr. White says. "The students had access to every simulation tool available, as well as support from The MathWorks. In the long run, exposure to these tools will enhance the students' careers both in terms of opportunities and richness."

In just their first year of the competition, students have already used state of the art technologieslike hardware-in-the-loop simulation, hybrid vehicles, safety critical systems engineering and others that aren't yet available commercially. "Exposure to these cutting edge technologies gives our students a significant advantage in the marketplace," explains Dr. White. "This competition also opens up new opportunities for graduates in markets that might not be as familiar with Embry-Riddle."
David Robertson-who is "absolutely fascinated with hybrid vehicle technologies" and is enjoying a little automotive competition himself by racing professionally in the American Le Mans Series-admires the EcoEagles. "There are a lot of really brilliant students at Embry-Riddle," he comments. "I would love to be 22 years old again and involved in a project like this. But since I can't, I'll support them as much as I can."

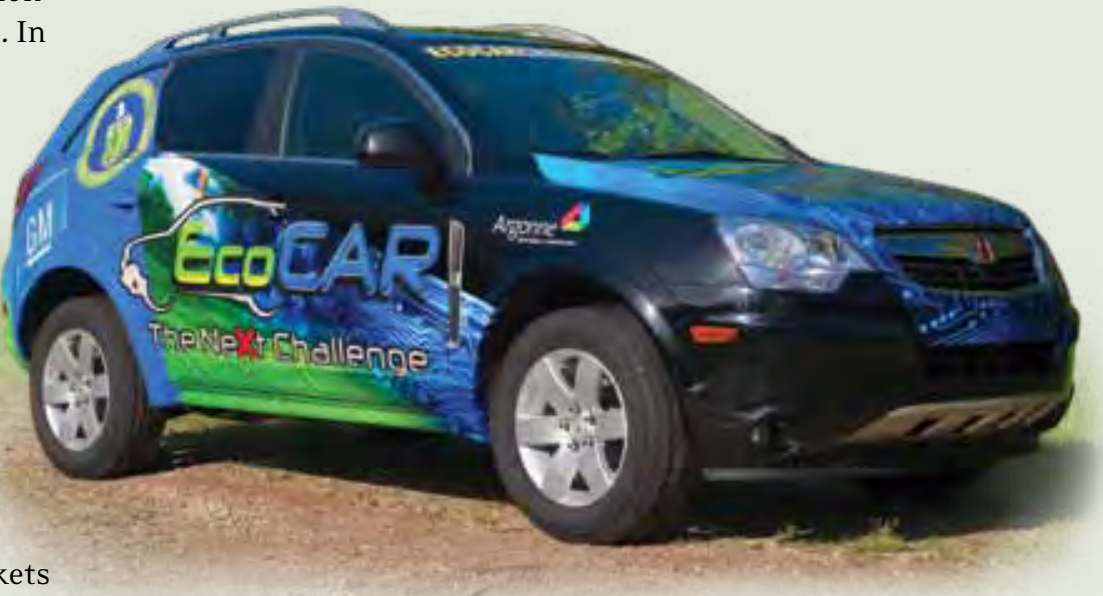




\section{RE C OG N I T I O N O F G I VING $\longrightarrow$}

\section{Squadron 500 (cont.)}

Brian Toung

Jerry Trachtman

Marilyn Wagner

Ingrid and Robert Weeks

David and Sharon Weiss

Charles and Deborah Westbrooks

Myles and Kimberly Wilkinson

James Wise

Jim Zeisler

\section{Squadron 250}

\section{Corporations and Foundations}

American Industrial Plastics

Aramark Uniform Services

Arizona Machinery

Atlanta Falcons

Bahama House

Baker Barrios Architects

Beach Photo \& Video

Best Western Aku Tiki Inn

Cable One

Center for Emergency Medicine of

Western Pennsylvania

Coleman Goodemote Construction Co.

Daytona Beach Area Convention \& Visitors Bureau

Daytona Beach Cold Storage Co.

Eagle Sport Aviation Club

Einstein Insurance

Fairchild Controls Corporation

Fish Window Cleaning

Georgia Aquarium

Greater Prescott Jaycees

Hilton Daytona Beach Oceanfront Resort

Investments Unlimited

JulBert

LaBosco Jewelry Castle

Lohman Offices LLC

Lutheran Community Foundation

Martin \& Associates PL

Elizabeth Morejon, D.M.D., M.S. PA

Ocean Deck

Palomino AG Sales LLC

Pelican Bay Country Club

The Pepsi Bottling Group

Perry's Ocean Edge Resort

Phoenix Aviation Managers

Public Service Enterprise Group

Raydon Corporation

Roberts \& Carver PLLC

Roush Fenway Racing

The Shores Resort \& Spa

StyleMark

Sybase Financial Administrators

Universal Studios Florida

Wachovia Corporation

Tony Welch Marketing

Yavapai-Prescott Indian Tribe

\section{Alumni and Friends}

Wilbur Anderson

Robert Applewhite ('77, DB)
Michael Ariano ('o3, DB)

Robert Armbrust

Thomas ('74, DB) and Jacqueline Arnold

Mark and Anne Ascik

Michael and Ersilia Ash

Magdy and Linda Attia

Nancee Bailey

Kelly Baker ('89, DB)

Edward ('73, DB) and Mary Ann Ban

Donna Barbie and Richard Kessler

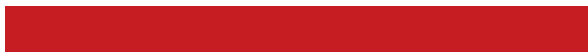

My father's passion for his job and for his students at Embry-Riddle had been evident to me since childhood and I always wanted to honor that dedication through a scholarship. We hope to make a key difference in the life of a student to enable them to obtain the education they need to succeed.

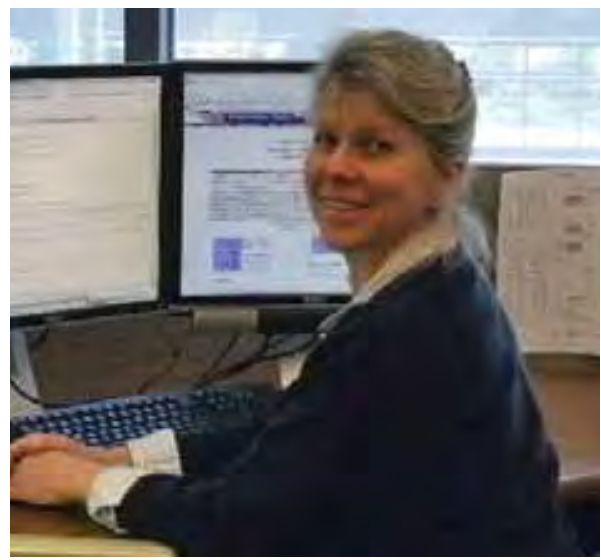

Linda Titus ('79, $D B$ ) on establishing the Titus Scholarship, which supports College of Aviation students on the Daytona Beach Campus.

Carlos Barrios

Paul Bartlett ('81, PC)

Alan Bender

Cynthia and Kevin Bixler

Thomas (' $75, \mathrm{DB})$ and Cheryl Blas

Chris and Brenda Boals

Samantha and Matthew Bohon

James ('91, '97, WW) and Betty Brown

W.L. and Ann Burt

William ('91, PC) and Michelle Calvo

Mark Campolong

Larry ('o5, WW) and Shirley Carlton

Barbara Carnes

Daniel ('go, WW) and Cheri Carrell

Jerry Carver

James Cieplak ('88, '99, DB)

Charles Coleman
Thomas and Barbara Connolly Bruce and Carol Conway James and Alison Cook Gerald ('59, MC) and Virginia Cox Deborah and Howard Creech

Matthew Crisci ('97, DB) and Donna Bembnister David and Marguerite Cummock

Philip ('99, 'o1, WW) and Tori Decker Joseph ('69, DB) and Janet Dickinson Vera Dillon

William Dollaway ('78, DB)

Camilo Dornier ('84, WW)

Daniel ('83, WW) and Elpa Droogleever

Edward and Fern Dytko

Dennis ('73, DB) and Beth Einstein

Eric and Cynthia Fisher

Howard ('78, DB) and Sharlene Fox

Elizabeth and Michael Frost

Oscar ('o4, DB) and Yvette Garcia

Albert and Doreen Gillespy

John and Marjorie Glyshaw

Harold Goodemote

Samuel and Cheryl ('o1, DB) Granata

Edwin ('85, WW) and Joanne Granberry

Daniel and Kathy Harrison

Leanne and Gary Harworth

Jack and Debbie Haun

Ron Howard

Robert ('42, DB) and Lorraine Hubsch

William and Grace Hunt

Joni Hunt ('86, '97, DB) and Mitch Whitlock

Alfred and Johanna Hurley

Glenda and Robert Jarrett

Glenn Jenkins

Nancy Jensen and David Aper

Russell Jensen

Philip Jones and Leeann Chen-Jones

Patricia Kabus

Gerald and Sally Kent

Richard Keough

Eileen and James Klein

Kirk and Pamela Knight

Martin Korges ('81, DB)

Andrew and Lucyna Kornecki

Valerie and Thomas Kruse

Donald ('72, DB) and Sandra Kuhfuss

John LaBosco

Raymond ('83, '99, DB) and Karen ('84, DB)

LaMarche

Joseph ('o1, DB) and Marietta ('o1, DB) Landon

Guy and Rowena Larson

Robert ('57, MC) and Roxie Lewis

Lowell and Nancy Lohman

Michael Long

Emmert and Margaret Lowry

Jacqueline and Marc Luedtke

Florence Machol

John ('96, PC) and Gail MacKay

Ronald and Tracy Madler

Douglas Martin

John ('76, DB) and Darlene Mazur

Debbie Miller 


\section{Lockheed Martin helps expand robotics development at Embry-Riddle Prescott}

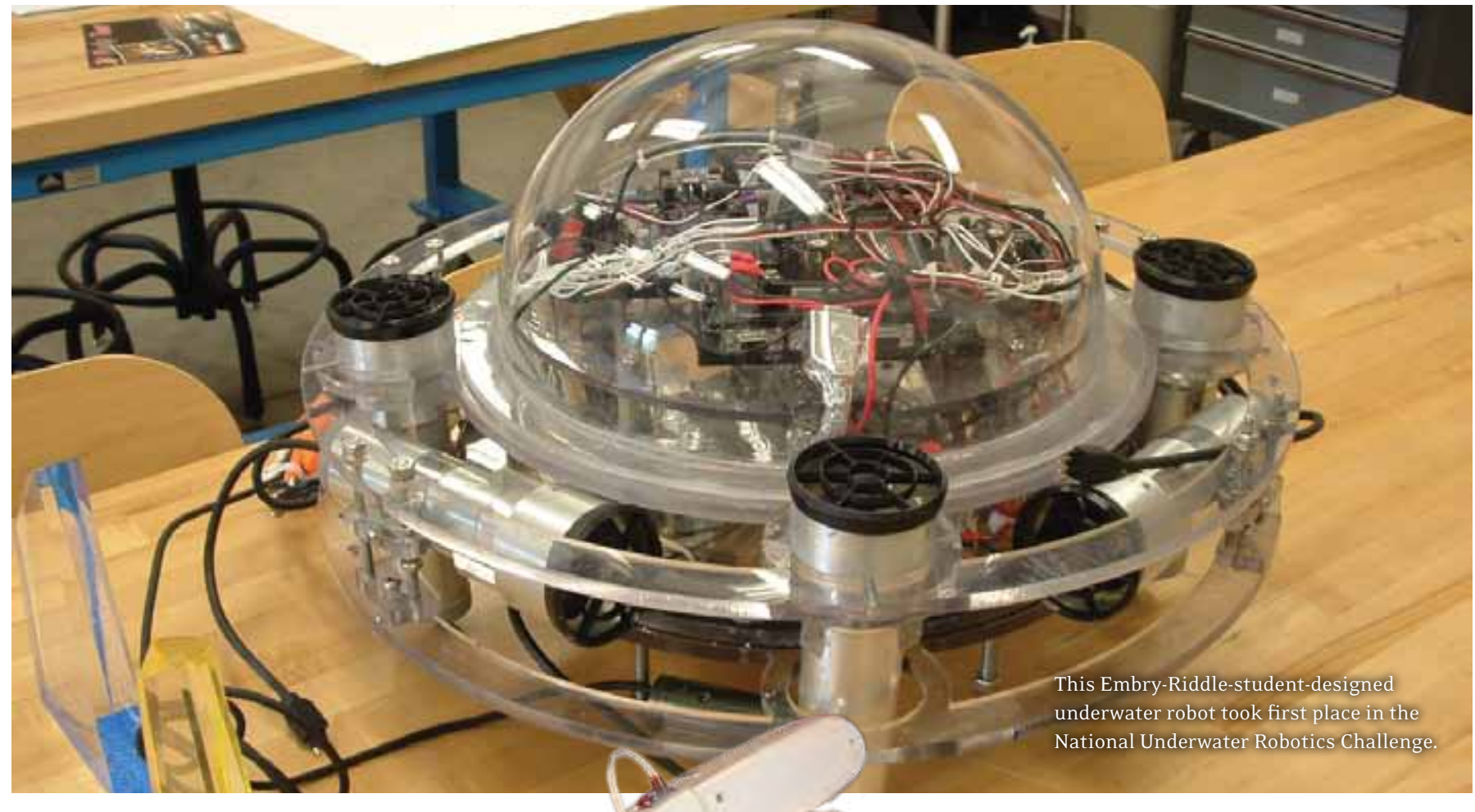

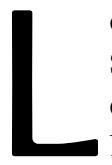

ockheed Martin has donated \$10,ooo to expand robotics exploration at the College of Engineering at Embry-Riddle's Prescott Campus. The gift will help more students learn about robotics and will help to promote interest and inspire innovation in the field, such as the student-designed underwater remotecontrolled rescue robot, "Medusa," which won first place in the university division at the National Underwater Robotics Challenge recently held in Chandler, Ariz.

Based on the University's mission to support robotics and unmanned aviation vehicle research, the Lockheed Martin donation is part of a recent expansion at the University, according to former Prescott Executive Vice President Dan Carrell. "Embry-Riddle has invested in a new Robotics Laboratory in the College of Engineering to support engineering

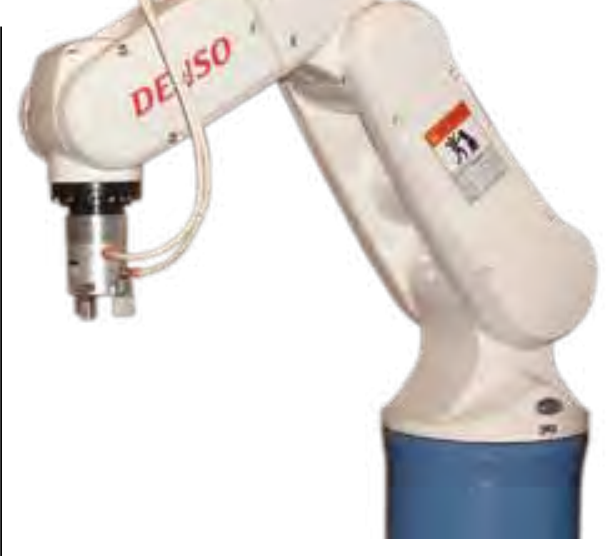

robotics education and student projects and to promote multidisciplinary robotics and autonomous vehicle research."

The Lockheed Martin gift will be instrumental in expanding the lab facilities to add a mechanical/electronics component to the curriculum. "Robotics, with their mechanisms, actuators, and sensors, are highly dependent on electronics for processing and control. A multidisciplinary education that includes electronics and realtime systems is key to preparing our aerospace and mechanical engineering students to help them develop their design approach, research, and future value to employers," said Dr. John Nafziger, head of the Robotics Laboratory. "We've added new computers and instrumentation for data acquisition and for real-time sensor filtering and motor control."

"We're proud to be able to support the communities where our employees live and work," said Dan Courain, vice president of Lockheed Martin Transportation Services. “It's particularly important to us that this gift will be used to encourage students' interest in science, math, and engineering, and inspire a future generation of aviation leaders."

$\uparrow$ 


\section{RECOG N I T I O N O F G I V I N G}

\section{Squadron 250 (cont.)}

Maj and Freshteh Mirmirani Dena Moore

John and Angela Mortland

Steven and Kulaea Naber

Louis ('76, DB) and Cindy Nemeth

Brian and Becky Nordstrom

Elliot and Barbara Palmer

Michael Panaggio

Linda Parker

James Parry ('87, WW)

David and Liz Paschal

Michael ('86, DB) and Joyce ('81, DB) Pepin

Ruthie and King Pickett

William and Wieslawa Pietrasz

Alan and Bonnie Pratt

Charles and Linda Pulaski

Julie Rand

Mel and Karen Ray

Bert and Julie Reames

Terry and Ann Reiber

Adam Ritchie

Paul Roberts

Douglas ('95, DB) and Michele Ross

Ryan ('o2, DB) and Brooke ('o4, DB) Rothrock

Peter ('89, DB) and Donna Rounseville

Jack Roush

Sandra and Vincent Saar

Keith ('99, DB) and April Schonrock

James ('o4, WW) and Marian Schultz

Mary and William Schwem

Lisa Scott-Kollar ('97, DB) and Matthew

Kollar ('99, 'o7, WW)

George Seibold ('72, DB)

Ronald ('86, WW) and Helen Sibley

Lewis Silverberg

Harry and Bobbi Smiley

Guy and Maryjo Smith

Raymond ('75, DB) and Wendy Springsteen

Richard and Amy Stansbury

Kenneth and Jennifer Staton

Thomas Stokely

Nancy Tamburello

Howard Taylor ('79, '8o, DB)

Sonja Taylor

Amy Tenney

Sarah and Terry Thomas

Rosaria and Paul Upchurch

Rebecca and Paul Vasquez

Marco Viola

Peter ('69, MC) and Linda Vosbury

Joan and Fred Wackowski

Josef Warfel

John Watret and Elizabeth Mathews

Paul ('78, DB) and June White

Darris and Melinda White

John Williams

Alfred ('82, WW) and Katherine Williams

Dan Williams

Michael ('88, DB) and Laurie Williams

Steven ('86, DB) and Marifrances Williams

George ('98, DB) and Konnie Willis
Robley ('o1, WW) and Sue Withrow

Maryellen Wynn ('9o, DB)

Floyd and Janis Young

Anthony and Mary Ziner

\section{Squadron 100}

\section{Corporations and Foundations}

A \& $O$ Investments

A\&T Builders

Accord Insurance Network of Ormond Beach LLC

Aero Supplies \& Express

Brent Allen Salon

Alliance Homecare \& Mobile Diagnostics LLC

Alpha Pool Cleaning LLC

American National Insurance Co.

Balfour Beatty Construction

Bayview Urgent Care LLC

Bon-Gourmet

Bowman Painting LLC

Hayward Brown

Consolidated-Tomoka Land Co.

Crotty Bartlett \& Kelly PA

Dental Creations of Daytona Beach PLC

East Coast Community Bank

Entech Controls Corporation

Erickson Chiropractic Clinic PC

The Frame \& Photo Works

Arnie B. Green

Halifax Sailing Association

Hannah Cremation Service Co.

Hill \& Ponton PA

Hot House Yoga

Hughson Nut

JumpTV USA Holdco

Karlhaus LLC

Raymond Kenzik, D.D.S. PA

Drs. Kraski \& Costello PA

Lago Grande HOA

Lewis Towers

The Little Gym of Port Orange

Massey Services

Robert C. McElroy, Ph.D.

McKenzie Associates LLC

Medi Day Spa at Pelican Bay by Cheryl

Microflex

National Fuel Gas Company Foundation

Natural Bliss

New Church Family

The News-Journal Corporation

Oceanside Inn

The Parking Spot

PB Stoolers

Pepin Realty

Prescott Student Government Association QPUBLIC LLC

$\mathrm{R} \& \mathrm{~S}$ Sporting Products

Raceway Foods Corp.

Red Square

Residence Inn Orlando International Drive

Ronin Sushi \& Bar

Royz Trucking LLC

SeaWorld Orlando
Sleuths Mystery Dinner Shows

Smith Law Office PC

Smith, Hood, Perkins, Loucks, Stout, Bigman,

Lane, \& Brock PA

Snell Legal

Solar-Fit

Sparton Electronics

Synergie Skin Studio

T.G.I. Friday's

William Thames \& Co. Jewelers

Top to Bottom Renovations LLC

Turbine Engine Support LLC

Walsh Consulting Group

WaterStone

Wet 'n Wild

World Golf Hall of Fame

Greg Wynn Financial Services

\section{Alumni and Friends}

Scot Abel ('o4, WW)

George ('89, WW) and Kay Adams

Jeffery and Nancy Adams

John and Patti Adams

Larry ('75, DB) and Karen Adams

Richard ('68, DB) and Jeanne Adams

Robert Adams ('o1, PC)

Genevieve Aiken-West ('93, PC) and Earl West

Jesse Akers Reagin

Tara Alexander ('91, DB)

John ('7o, DB) and Sandra Allen

Samuel ('71, DB) and Robin Allen

Brent Allen

Cynthia and Charles Allen

Robert and Carol Allen

Jessie Alvarez ('82, WW)

David ('58, DB) and Marilyn Anderson

Kent ('97, '99, WW) and Teresa Anderson

Larry Anderson

Earl and Virginia Arbuckle

Cherie Armstrong-Cadenhead and Randall Cadenhead

Anke and Martin Arnaud

Allison Ashe

Michelle Atanasoski

Steven ('97, WW) and Vanessa Austin

William Baker

Muneer ('96, '99, DB) and Linda Bakhsh

Lubomyra Bardygula ('87, DB)

Beverly ('o1, WW) and Donald Barker

James Barnard ('96, DB)

Bill and Sonya Barnes

Lawrence Bartlett and Kathleen Crotty

William ('6o, MC) and Joelin Bayer

Eileen Beall

Louis Beaulieu

Thomas ('85, WW) and Sharon Bedisky

Debby Bell ('88, PC)

Paul Bell

Mark ('o4, WW) and Connie Bellnap

Jamie Belongia

Barry and Alicia Benjamin

Richard ('66, MC) and Gina Bennert 


\section{$\longleftarrow$ R E C O G N I T I O N O F G I V I N G}

Harold and Carol Bennett

Arthur ('82, DB) and Linnett Benson

Michele and Per Berg

Michael ('75, WW) and Glenda Bergagnini

Kaye and Mark Berman

Paul and Maria Bigelow

Margaret ('84, PC) and Thomas Billson

Mezdi ('74, DB) and Meena Birdie

Christopher ('88, PC) and Cheryl Bischof

Robert and Maureen Bittner

Robbin and Jon ('93, '97, WW) Blake

P. Andrew ('88, DB) and Katherine Blatt

Harry and Joyce Boden

Richard ('85, DB) and Lisa Bodenski

Evan ('95, DB) and Sarah Bogan

Jessica Bohan

William Bold ('76, DB)

George and Susan Boutin

Christopher ('9o, DB) and Keely Bovais

Scott Bowman

Jeffrey and Kristy Brancolini

James ('84, DB) and Pauline Brannigan

Matt and Mary Brasmer

Carlos and Patricia Bravo

Kevin ('95, WW) and Pamela Brewster

George and Shannon Brinkman

Nick and Maureen Brixius

John and Sheree Brodak

Anthony Brown and Michelle Pack-Brown

David Brown ('89, WW)

J. Hyatt and Cynthia Brown

Shannon and Jay Brown

Richard and Marjorie Bryant

R. Scott Bunn

William and Susan Burchfield

Richard and Doris Burrell

Nathaniel ('98, DB) and Suzanne Burt

Layna Buskirk

Norma Butler ('o3, WW)

Donald ('79, DB) and Anita Byrne

Carl and Debra ('o8, WW) Cady

Mark ('o4, WW) and Jean Cady

John and Michele Caldwell

Jacob ('78, DB) and Kim Calo

Ronald ('81, '85, WW) and Marian Caraway

Paul Carroll

John and Elizabeth Casbeer

Patrick ('84, DB) and Carol Casey

Ann Cash-Wolf

Charles ('68, DB) and Pamela Causey

Ralph Chaffin ('9o, '91, WW)

Ruth Chang

Rebecca and Rod Chapman

William and Joella Cheek

Kathleen and Michael Citro

Douglas ('81, '91, DB) and Kimberly Clark

Brian ('91, DB) and Kristina Cobb

Terry Cobb

Patricia ('oo, WW) and Richard Cody

William and Gail Cody

Charles ('95, DB) and Katrina Coldren

James Copp ('o2, WW)
William and Devora Corbin

Stanley Coss

Fredrick and Linda Costello

Edward Courtemanche ('o8, PC)

Joann ('o2, WW) and Christopher Courtland

Lynn and Russell Cox

As a Prescott Campus college student, I wouldn't have been able to obtain my degree had it not been for a lot of generous people.

I always believed that I would try to help people like me if I was ever in the position to do so financially. My yearly donation to Embry-Riddle is my way of giving back.

\section{Embry-Riddle is a relatively small} university that caters to my passion: flying. The field of aviation needs support and we need young people to continue to live out their dreams of flying and designing the aircraft of the future. Giving to Embry-Riddle is a way to provide that support.

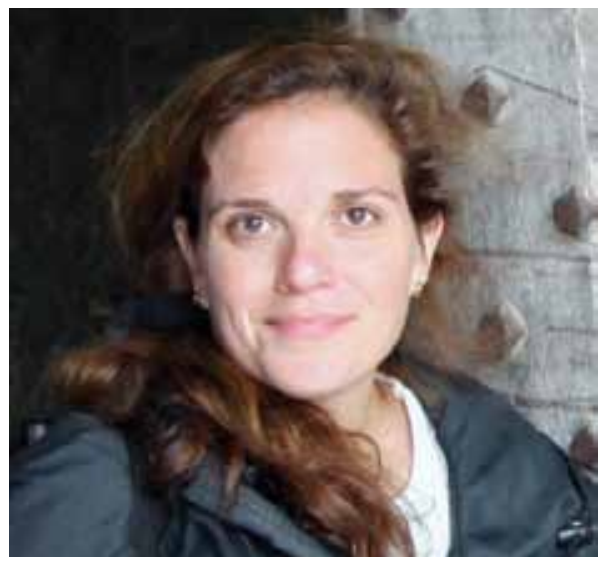

Cheryl Hodge ('92, PC) on why she supports the Prescott Campus with her annual gift.

Walter and Jan Craig

James Crater ('83, DB)

Robert ('93, WW) and Kathryn Craven

Roger Crawford

Charles ('73, DB) and Carole Crescioni

Michael and Kristen Crotty

Deane and Catherine Cruze

Kerry and Debrah Cruze

Mary Custureri

Laura Cutlip ('97, DB)

William ('85, WW) and Angela Cyr
DeeAnn ('o4, WW) and Mark Danin Zuheir ('o4, WW) and Farah Darugar Lisa and Matthew Davids Leonard Davis ('o4, WW)

N. Rick Dawson

Daniel De Lara ('o7, WW)

Frank De Mary ('91, '97, WW)

W. Edward and Ruth Deaton Gary ('8o, WW) and Karla DeKay John Denigris

Peter ('82, DB) and Beverly DeNucci

Peter and Noreen Di Mento

Daniel ('83, DB) and Diane Di Sebastian

John and Louise Dianto

Anthony ('8o, DB) and Jill Diaz

Thomas Divine (' 76 , DB)

Robert ('o4, WW) and Teresa Doheny

Adrienne and Edward Dominello

Walter ('7o, DB) and Annamarie Donovan

Diane and John Dowhy

Peter Dulken

Howard and Laura Dulmage

Molly Dulmage ('o8, PC)

Richard and Mary Alyce Duma

Shanon ('69, DB) and Sue Dunlap

Tom Dunn

Wesley and Rosanne Dunn

William Dunn

Thomas Durbin

Charles and Linda Eastlake

Kenneth ('72, DB) and Bonita Eckel

Frank and Kathryn Eddy

Al Eichenlaub

Paul ('69, DB) and Judith Eldridge

Daniel ('88, WW) and Kay Eramo

Steven and Cristi Erickson

Peter and Dawn Eslick

Barbie Esquibel

David Esser ('81, '87, DB)

Scott ('96, DB) and Debra Evans

Michael and Denise Eyer

Daniel ('o4, WW) and Elaine Fasone

Glenn Favre ('o6, WW)

Rebecca ('o4, WW) and Jeremy Fenstermaker

Richard ('9o, '95, DB) and Christine Fetchik

Ronald ('75, DB) and Anne Fisher

Philip and Susanne Fleuchaus

Brian Florence ('91, PC)

Joseph Flynn ('05, MC)

Robert ('71, DB) and Cynthia Fogg

William ('o7, WW) and Susan Ford

Mark and Julia Fortier

David Franklin ('85, DB)

Malcolm and Anne Fraser

Quentin ('o3, DB) and Yolanda Freeman

Mark and Kathy Friend

Bradley ('82, DB) and Judy Fritzges

Curtis ('84, PC) and Nancy Frost

Sun-Yiu and Helen Fung

James and Mary Lou Furaus

William and Carol Gallagher

John Gamin 


\section{REC OG N I T I O N O F G I V I N G}

\section{Squadron 100 (cont.)}

Oscar and Diane Garcia

Kenneth ('o4, 'o6, WW) and Carol Gardy

Adam Gartner ('o3, WW)

Bonnie Gauger

Christopher ('97, WW) and Tamara Gavin Gregory Gaze ('85, WW)

Kent ('71, DB) and Barbara George

Leslie Gibbs

Randall ('89, PC) and Celina Gilhart

Gregory Ginnetti ('93, DB)

Timothy Glover ('8o, DB)

Reid ('76, DB) and Hanna Golden

Janice Goodwin

Daria Gori

Steven ('94, WW) and Darlene Gottschalk Michael ('96, DB) and Penny Gowen

Christopher and Cynthia Grant

Arnold Green ('77, DB)

Larry and Ann Grimm

John ('74, WW) and Glenda Grones

Lawrence ('87, PC) and Maureen Guichard

Vitaly ('oo, DB) and Ekaterina Guzhva

Jeffrey ('69, DB) and Carol Haggas

Harlon ('84, WW) and Virginia Hain

Clint ('8o, DB) and Audrey Hamilton

Robert and Martha Hannah

David ('9o, DB) and Monica Hanzlik

Jeffrey ('8o, DB) and Christina Hardy

Nathan and Erika Hargrave

J. Kenneth Harkins ('87, WW) and

Stephanie Brundage

Edward Harley

Philip and Marilyn Harman

Roberta Harney

Shaun and Rebecca Harney

Robert and Heidi Harsha

Michael and Carol Harter

Matthew Hartgen ('85, DB)

Thomas ('87, DB) and Kimberly Hartstein

Roger Harvell ('9o, DB)

Robert and Cheryl Hasychak

Christopher Hawzen ('o3, DB)

Alex Haynes ('91, PC)

Henry and Roy Sue Hays

Lee and Mary Hays

David and Mary Ann Hazen

Jerry ('91, WW) and Donna Heck

Leo and Dianne Heidemann

Richard and Mary Heist

James Helbling

Steven ('8o, PC) and Linda Henderson

Thomas Henkel ('o4, WW)

Neil and Ann Hennessy

Vern and Laureen Hensley

Roy ('75, DB) and Sandra Hepler

Thomas and Judith Hilgers

Brian Hill

Kathy and George Hill

Paul ('84, DB) and Karen Hocking

Russell ('89, WW) and Donella Hodgkins

Michael and Kathleen Holmes
Frank Hoover

Chip ('88, DB) and Ann Marie ('92, DB) Hough

David Houlette ('o1, DB)

Scott Howard ('97, 'o1, WW)

Cass and Mary Howell

Barry ('78, DB) and Jeanne Hoy

Harry and Dolores Hugber

Reid and Nancy Hughes

Arthur and Vicky Huie

William Hummel and Lisa Faston-Hummell

Richard Jacobs ('85, DB)

Anthony ('83, DB) and Patricia Jansa

Timothy ('o5, WW) and Deborah Joca

Joseph Jones ('68, DB)

Alan and Cecelia Jorczak

Ben (' 56, DB) and Dahlia Jung

Deborah Kane-Cottini ('83, '84, DB) and

Martin Cottini

Georgia and Jonathan Kaney

Marshall and Linda Kaplan

Roy and Diane Kawawaki

Steve and Amy Keast

Cheryl Keemar

Greg Keller

Katherine Keller

Kevin ('73, DB) and Diana Kelly

John Kennedy ('88, DB)

Raymond and Mary Lou Kenzik

William Kerr ('6o, MC)

Theodore ('79, WW) and Pamela Key

Max Kim

Orion and Carole King

Mark Kinnane ('81, DB)

James Klina ('77, WW)

Richard ('85, DB) and Janice Klinker

Donald ('51, WW) and Mary Klopp

Mary Ann Kluga ('81, DB)

David ('74, DB) and Sara Kostek

James Kotas

Natalia Kozyura ('o4, DB)

John and Laura Kraus

James ('85, WW) and Jane Kula

Jean La Rosa

Charles LaBow ('71, DB) and Connie Labow

Warren ('64, WW) and Pamela Lackie

Robert ('74, '8o, DB) and Linda Ladd

Mary Lahann

Eduardo and Regina Lalli

Carol Lamattina ('86, '99, WW)

Christopher and Tracy Lambert

Michael Lange ('83, DB)

Dennis and Janet Langford

David and Lisa Lanning

Robert ('73, DB) and Jeanne Larive

Linda and William Larkin

Keith and Rita Larson

Thomas ('ol, WW) and Margaret Larvia

Herve Lavenant ('o5, DB)

Virden Laws ('o6, WW)

Corl ('o1, WW) and Julie Leach

Matthew and Christine LeBlanc

Michael ('83, DB) and Patricia Lebo
Robert Lee ('o1, WW)

Yoon-Woo Lee

Paula Lehman Pezet

Steven ('92, '95, DB) and Kellie Lehr

Wade ('o1, WW) and Debbi Lester

James and Joyce Libbey

Anne Lineberger

Stephen and Tammy Linn

Victor ('o3, WW) and Marlene Liriano

Lawrence and Barbara Litscher

Lascelles Longmore ('91, WW)

Mark ('92, DB) and Anna-Lisa Lonier

David ('7o, DB) and Deborah Lowe

Alice Lowenthal

Brian Lubinski ('05, 'o8, WW)

Dan and Victoria Lupin

Holly Luzader ('84, DB)

James ('81, WW) and Madelyn Lynch

Ernest and Eileen Ma

Douglas and Catherine Mac Laughlin

Murdock MacGregor ('91, DB)

Janice MacKenzie ('84, DB)

Jeanne MacPherson ('o4, WW)

Dirinda Maddy

Paul and Lizbeth Mahon

John Mahone

James and Karen Mahoney

Marcelo Maia ('o5, PC)

Juan ('84, DB) and Anna Mak

Nicholas and Mary Manderfield

Michael and Rebecca Manning

Michael Mantovani ('89, DB)

Jennifer ('89, PC) and Scott Maples

Brenda ('9o, PC) and Yudi Mares

Donald and Carol Maresca

George ('77, DB) and June Marhefka

Janet and Michael Marnane

Roxy and Marian Marrese

Bryan and Sally Marsh

Richard and Ann Martorano

Ira Mason ('05, '06, WW)

Doris Masotti

Patsy Masotti

Robert and Sharyn Materna

Jon Mayer ('o5, WW)

William and Stephanie Mayfield

James ('96, WW) and Beverly Mayhew

Daniel Maynard ('o2, PC)

David Mazoff ('72, DB)

Dan and Norma Mazur

Maranda McBride

Mary and Harry McConnell

George and Karen McCown

Michael ('9o, WW) and Deborah McDonald

Robert and Agnes McElroy

Scott McEvoy

Frank McFall ('89, PC)

Cheryl McIntire

Brian Mckenzie

Kevin ('97, WW) and Nina McPherson

Irene ('9o, DB) and Philip McReynolds

Ward and Terry Mead 

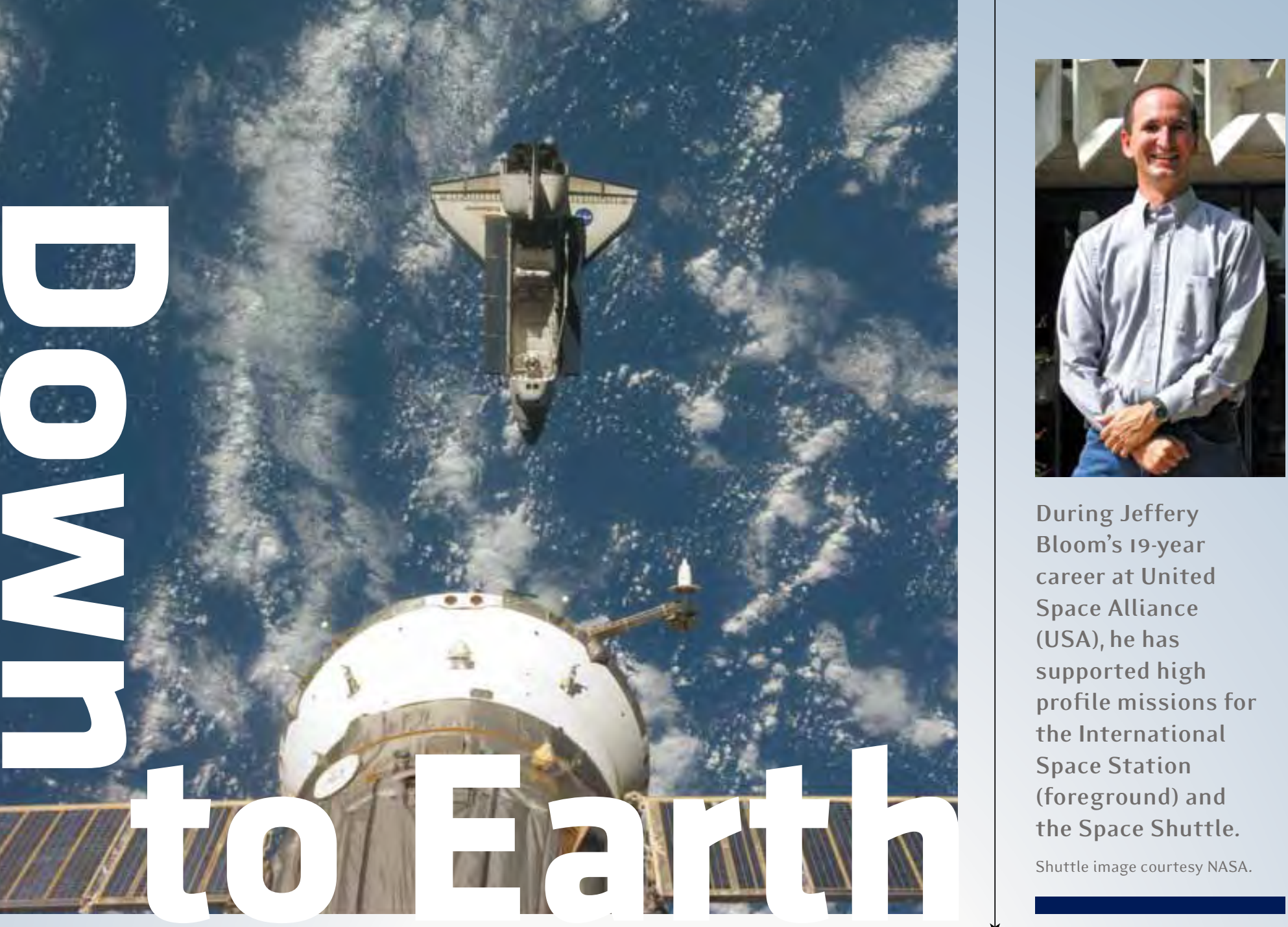

During Jeffery

Bloom's 19-year

career at United

Space Alliance

(USA), he has

supported high

profile missions for

the International

Space Station

(foreground) and

the Space Shuttle.

Shuttle image courtesy NASA

\section{Jeffery Bloom ('88, PC) supports the future of space by supporting students at ground level}

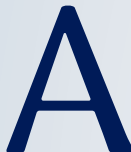

$\mathrm{s}$ a software engineer for

United Space Alliance at the

Johnson Space Center, Jeffery

Bloom ('88, PC) has spent the

last 19 years supporting missions- like the Space Station and recent Shuttle mission STS-127-that are literally out of this world. But Bloom has remained down to earth when it comes to a different kind of support: providing funds to prepare the next generation of space professionals.

Early on from his days as a graduate from Embry-Riddle's Prescott Campus, Bloom wanted to give back to those who had prepared him for his own career.

"When I graduated from Embry-Riddle, I felt prepared and confident to find a job," he recalls. "The university sent me on my way in a positive direction, and because they helped me, I want to give back.”
Today, Bloom still believes Embry-Riddle is leading students in the right direction. It's one of his motivations for his ongoing support. "I believe the university's focus on aerospace and aeronautics is right on track, and that's why I support them," he says. "They are doing the right thing for the future, and I want to be part of it."

Being a part of the future is important to Bloom, especially when it comes to America's space program.

"In the space program, we are always being asked if qualified people are being trained for this work in the future," he explains. "By supporting Embry-Riddle's engineering students and programs, I believe I'm doing my part to make sure graduates are prepared to work in the space program."
Whether his gifts are used for student scholarships, new equipment, computers or other College of Engineering needs, Bloom knows they will contribute to a brighter future for students and the university. "I know my gifts are being used where they're needed, and I trust the university to determine those needs. By helping the students and the engineering program, I know it is helping the university grow and maintain their leadership position in the aeronautics field," he says.

Bloom knows first-hand that it takes a group of people to make a mission successful, and he takes the same attitude towards giving to Embry-Riddle. "If we all help a little bit, we can do a lot.” 
hile most individuals and organizations make direct contributions to the university, there are a significant number who contribute to the Embry-Riddle mission by directly supporting its most important asset: students. In the past year, external organizations and individuals provided nearly \$1.4 million in support of Embry-Riddle students directly through scholarships.

The National Aircraft Finance Association (NAFA) is one such leading organization. Dedicated to supporting students who seek business careers in corporate aviation (especially within the corporate aircraft finance, legal and insurance communities), NAFA has partnered with Embry-Riddle to ensure that students are prepared for future industry challenges-students like Angelica Maleskis (facing page) who received the NAFA scholarship.

\section{In addition to NAFA's support, Embry-Riddle would like to acknowledge those individuals and organizations that contributed $\$ 5,000$ or more in scholarships to students attending Embry-Riddle:}

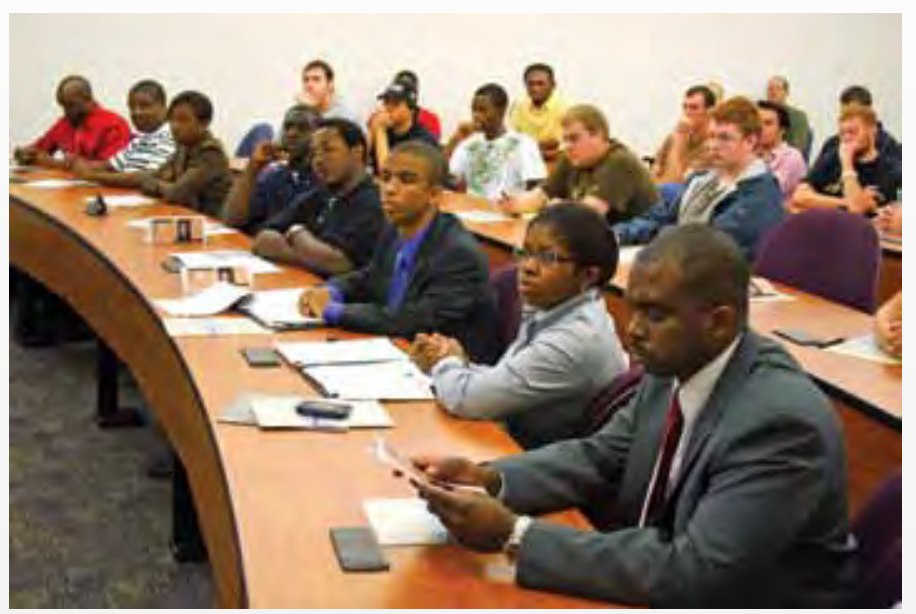

Organizations like the National Aircraft Finance Association are providing scholarship support for students seeking careers in corporate aviation.

"We are delighted to support the academic endeavors of Embry-Riddle students seeking careers in these select areas of corporate aviation," stated Michael Amalfitano, Ex-Officio on the NAFA Board of Directors, who spearheaded establishment of the NAFA Scholarship during his tenure as president of NAFA. "Many Embry-Riddle graduates are employed within the corporate aviation industry, and we believe NAFA can help develop future industry leaders.”
ACT Horatio National State

Army Emergency Relief

Brown University

Cater Bank \& Trust

Chickasaw Nation

Chuuk State Government

$\mathrm{CN}$

Columbia University

Community Foundation of Louisville

Cornell University

Daedalian Foundation

Daniels Fund

Duke Corporate

EBPA

Fabricators \& Manufacturers

Association
Families of Freedom

Fund for Public Schools

Gates Millenium Scholars

Gen. Henry Arnold Education GrantACT

Gila River Indian Community

GMAA Batchelor Aviation Scholarship

Hispanic College Fund

Huether-McClelland Foundation

J M Rubin Foundation

Johns Hopkins Univiversity

Josephine Tatum Foundation

Kennedy Krieger Institute

Kisco Foundation/Scholarship America Mayo Foundation

McKee Scholarship/CFFK

\section{NASA MUST PROGRAM}

National Business Aviation Association

National Action Council Minorities Engineer

Nevada Joint Union District

Parker Hannifin

Paul Pigott Scholarship Foundation

Princeton University

Robert D Foster, Inc.

Sam Walton Community Scholarship

Scholarship America

Smith College

Stephen Phillips Scholarship Fund

The Community Foundation of

Sarasota, Inc.

Walter Beale/Past Regional Presidents of the Fleet Reserve 
U niversities are often judged by the quality and achievements of their students and graduates. By increasing support for scholarships, Embry-Riddle secures the best and brightest students for its classroomsregardless of their financial status-and it produces graduates who make a difference.

Angelica Maleskis, already a great student with a 4.o GPA in the Aviation Business Administration program, hopes someday to be a high achieving graduate as well. Thanks to ample scholarship support during her studies at Embry-Riddle, the senior (and eventual graduate student) is well on her way.

"Ultimately, I plan to become a manager of an airport in the United States," she says. Working part-time as a supervisor in the Daytona Beach International Airport kiosk and interning at Boeing in the summer have laid the groundwork for her ambitious career goals-none of which would be possible without the scholarship support she's received.

"I rely heavily on scholarships to help fund my education at Embry-Riddle, so every scholarship is extremely beneficial," Maleskis says. "Scholarships prepare students to be successful aviation leaders, and provides them with the chance to get the best education possible."

\section{Scholarships secure a bright future for students and industry}

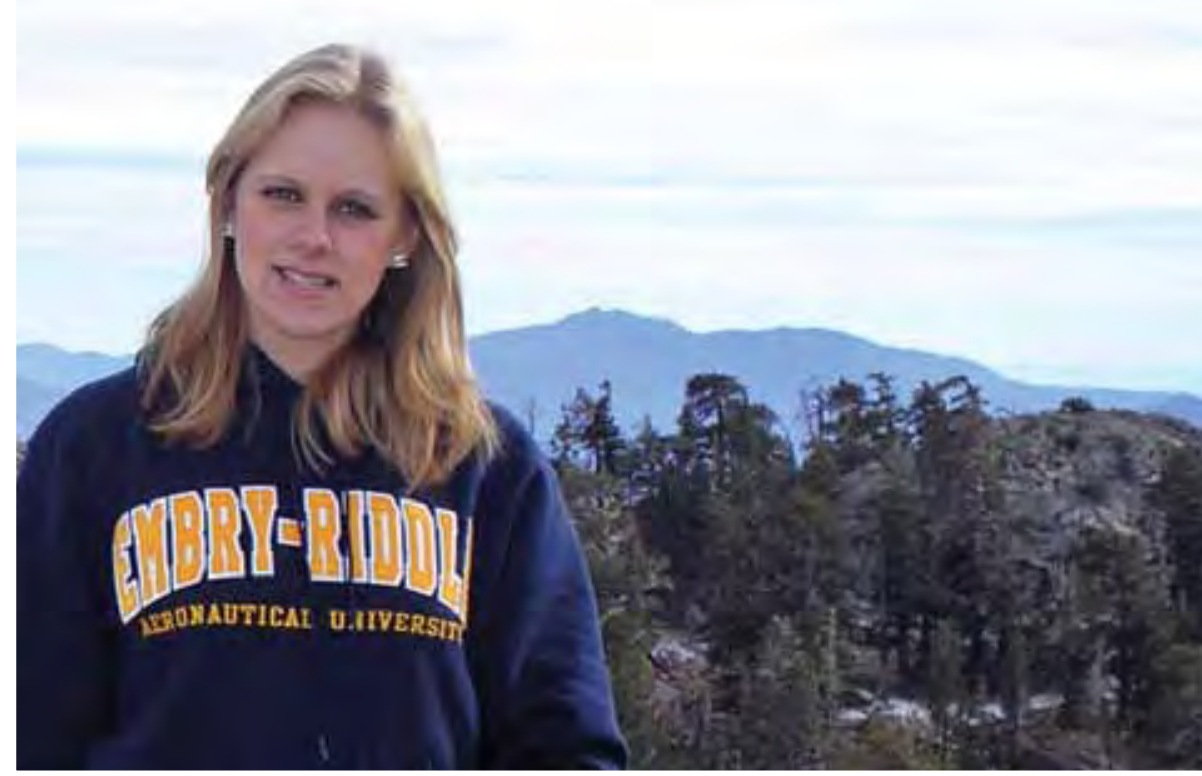

Embry-Riddle would like to thank the following donors who have contributed $\mathbf{\$ 2 , 5 0 0}$ or more to term scholarships in 2009 that provide annual support to help students like Angelica Maleskis achieve their dreams:

American Volunteer Group

John ('73, DB) and Donna Amore

Blackhawk Flight Foundation

Boeing Company Charitable Trust

Chartwells

Lawrence and Barbara Clarkson

Robert and Jennifer Crouch

Michael ('76, DB) and Pamela DeGiglio

Florida Aviation Trades Assoc.

Florida Independent College Fund
David Gordon ('8o, DB)

Halifax Health

Thomas and Ann Hilburn

Paul B. Hunter and Constance D. Hunter Charitable Foundation

Huntzberry \& Son

Marmot Foundation

George Mendonca

James and Karen Muff

Oliver Wyman

Deborah Lee Prescott
Gordon and Celia Ritter

S. Harry and Linda Robertson

Rockwell Collins

Nancy Ryba

Estate of Wesley Segner

Thomas and Doris Sieland

Estate of Maurice F. and Dorothy D. Taylor

TBM Owners and Pilots Association Linda Titus

The Wings Club 


\section{Squadron 100 (cont.)}

Ryan ('96, DB) and Ronda Meere

Steven and Patricia Merchant

William ('93, DB) and Shannon Metera

Joann Mican

Marilyn Middendorf

Gordon and Virginia Millar

James Milsom

Christopher ('92, PC) and Linda Minar

Grover ('81, DB) and Joyce Mirgle

John and Anne Miseyko

Peter Modys ('79, DB)

Zulfiqar Mohammed ('96, DB)

Stacie and Donald Montgomery

Christopher ('87, WW) and Rita Moore

Nancy Moran ('o2, DB; 'o6, WW)

James ('75, DB; '9o, WW) and Michele Moreland

Charles Moren ('79, '9o, DB)

David ('97, DB) and Stephanie Morker

Gary ('63, DB) and Angie Morton

Jill Muckenthaler

Wayne and Kathleen Munson

Ronald ('72, DB) and Katherine Murphy

Gary ('57, MC) and Sandra Myers

Phyllis Naber

John ('94, WW) and Laura Nagle

Richard and Jean Nannariello

Marc ('7o, DB) and Terri Nathanson

Jeffrey (' 74, DB) and Sally Neal

Donald Needham

James and Joy Neikirk

Michael ('84, WW) and Anita Nemmers

Alexandria Newell ('o2, DB)

Peter ('91, WW) and Debra Newell

Jo Ann Newton

Cuong and Bichthu Nguyen

Kenneth ('98, WW) and Elaine Nichol

Charles Niederhaus ('91, PC)

Varun ('89, DB) and Trusha Nikore

Ronald (' 97, WW) and Nancy Nolder

Kelly ('99, WW) and Connie Noler

Theresa Nolte

Anita Nordbrock

Christopher ('o2, WW) and Karen Norfolk

Kevin and Lynne Norris

Kenneth and Edna Norton

Tracy and Linda Nuckolls

Joseph ('93, WW) and Kathryn O'Brien

Michael ('78, DB) and Carol O'Brien

Robert O'Brien ('86, DB)

Matthew O'Donell ('o2, DB)

Sarah O'Dwyer Mulready ('83, '86, DB) and

Scott Mulready ('83, DB)

John ('67, DB) and Kathleen O'Farrell

Shawn Olanyk ('96, DB)

Gregory Omboni

Patrick Opalewski

Tito Ortega

Gabriel ('05, WW) and Terri Ortegon

Jeffrey ('89, DB) and Sherri Osterlund

Barbara Overby

Gordon ('96, '98, WW) and Laura Palmer

Vincent ('9o, '91, DB) and Jennifer Papke
Jeffrey Parker ('o1, WW)

Dawn Parr

Kathryn ('95, DB) and Kenneth Parsons

Denise Paterno

Joseph and Jennifer Pauwels

Wendell Payne ('05, WW)

Tyler ('o8, WW) and Maria Pearce

Bradley ('87, WW) and Mary Jayne Pederson

Bradley ('82, DB) and Karen Penrod

Terence and Teresa Perkins

Bryan Perraud

Diane Petrusich

Valmore and Linda Picotte

I want to see ERAU thrive and succeed. It's a great platform for those who have an interest in aviation to learn the field and learn it with others who have a similar passion. Our support helps those folks. Many of us end up through timing or luck to be blessed with good careers, and it's incumbent on us to give some of that back to the institution that gave us some of those opportunities.

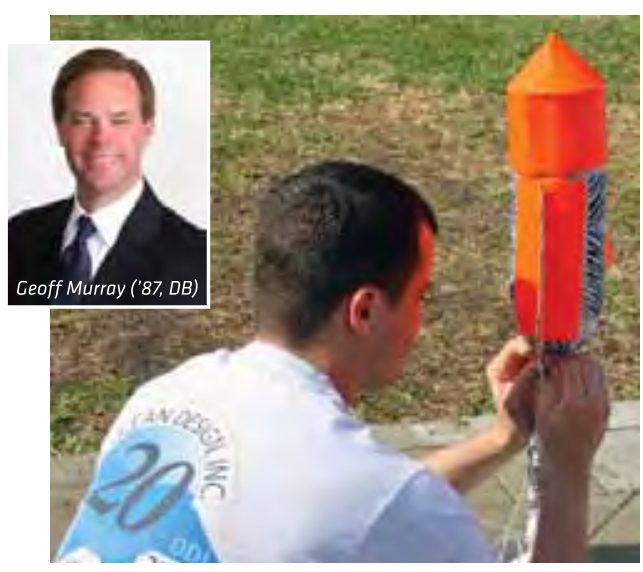

Geoff Murray ('87, DB)-President's Advisory Board member and Managing Director at Macquarie Capital (USA) Inc. -on why he supports EmbryRiddle's College of Engineering programs, like the rocket design project pictured above.

Philip and Pamela Piraino

Virgil Pizer ('84, DB)

Stanley ('oo, WW) and Kerri Pleban

Donald Pointer ('9o, DB) and Luann Spalla-Pointer Christopher ('89, '92, DB) and Ann Marie Polhemus Kelly Powell

Delbert Pratt

James ('69, DB) and Susanne Price

James (' 90, PC) and Jacqueline Privee

Robert ('95, DB) and Cynthia Proctor

William ('83, DB) and Kim Pytko
Allen ('75, DB) and Valorie Qualey Richard Rafes

Michael ('o2, DB) and Rita Ragoza Thomas Rajala and Daniele Hagen Hector and Laurie Ramirez James and Patricia Ramsay Thomas and Debra Randle Walter ('88, DB) and Nancy Ranft Michael ('88, '94, DB) and Laura Rapuano George and Gloria Ratcliffe Jeffrey ('92, WW) and Teresa Redder Claude ('61, MC) and Margaret Redmon Paula Reed

\section{Judith Rees}

David and Alexandria Remey

Kim ('73, DB) and Nancy Remmel

Deborah ('86, PC) and William Rhinesmith

Paul ('83, PC) and Linda Rhodes

Anthony ('91, DB) and Christine Ricci

Gerald ('94, '96, WW) and Suzanne Richardson

Kees ('05, WW) and Elizabeth Rietsema

Eliseo Rindinella

Roy and Ruby Rivera

Richard and Peggy Roach

Helene Roberson

Robbie Robinette and Brenda Curtis

Constance ('o1, WW) and Alan Robinson

David Roe ('o4, WW)

Dean ('87, DB) and Melissa Rosenquist

Michael and Carrie Rosolino

Bruce ('o5, WW) and Beverly Rothwell

James ('o7, WW) and Sophia Rowe

Thomas ('84, PC) and Sonia Rowe

Jody Rubin

Juan Ruiz ('o1, 'o6, DB)

Raymond Rusche ('81, DB)

Richard and Wilma Russell Jonathan ('81, DB) and Tracie Ruzicka

Cristin Rydzewski

Michael Rymond ('99, WW)

Sandra Safarik

William Sambolt ('87, WW)

John ('88, WW) and Barbara Sand

Ronald ('64, DB) and Ronnye Sands

Luis ('75, DB) and Liliana Santiago

Willard ('98, '99, WW) and Susan Sawyer

John Schaer ('o1, PC)

Joseph and Kristin Schafer

Gwen ('94, '98, WW) and Michael Schallow

Barry ('94, WW) and Dorie Schiff

David ('75, DB) and Lois Schilstra

William ('84, DB) and Lori Schrock

Morgan Scott ('o7, PC)

Robert and Esther Seelig

Dwight and Sheryl Selby

Charles and Benedicte Sevastos

Conrad ('62, MC) and Marcia Shad

Robin ('05, WW) and Sandra Shaffer

Paul and Lu Shane

Elaine Shank

Scott ('89, PC) and Taitia Shelow

John and Yvonne Shelton

Vicki Lynn Sherman 


\section{$\longleftarrow$ R E C O G N I T I O N O F G I V I N G}

Anita and Frank Sholtes

Roland ('72, DB) and Patricia Sicotte Jeffrey Sidwell

Joseph ('94, '05, WW) and Donna Sims James ('78, DB) and Linda Singletary

Gulamabus and Nargis Sivjee

David ('86, DB) and Barbara Siwa

Kelvin Sizemore ('96, WW)

Alison Sleight ('93, DB)

Paul Smith ('85, WW)

Horace and Theresa Smith

Buck and Carolyn Smith

Jacob Smith

Marvin and Connie Smith

Taylor ('81, DB) and Sheila Smith

Terry Smith

Vicki Smith ('oo, DB)

Theodore Smithers ('o3, WW)

Robert ('83, DB) and Bethanie Smithley

Gregory and Marjorie Snell

Janice Snyder ('98, WW)

Michael and Valarie Snyder

John Soldner ('84, DB)

Alice Gee Soon

G. Wayne and Sheila Sovocool

Eddie ('98, 'oo, WW) and Rosemary Spivey

Lynn Stauffer

Stanley Steenbock ('73, DB)

Charles and Melanie Stegall

Michael and Laura Stegall

Heidi Steinhauer ('94, 'o3, DB) and

Raul Rumbaut ('86, 'o3, DB)

James Stepnoski ('84, DB)

Helen Stickney ('o3, WW)

William Stockbridge ('74, DB)

Bob and Shirley Stokes

Robert Stokes ('99, WW)

Kathy Styer

David ('o7, WW) and Tami Sublette

Dale and Michael Sullivan

William Sullivan ('87, WW)

William ('53, MC) and Yula Swafford

Geoffrey Tacher ('o6, DB)

Raymond Tanguay ('93, DB)

Cynthia ('86, '94, DB) and Ernest ('86, DB) Tavares

Thomas ('78, DB) and Judith Terryn

Patti Thames

Gary and Mary Thomas

Holly and Thomas Thomas

Pamela ('9o, WW) and William Thomas

King Thompson ('o5, WW)

Margaret and Bruce Thompson

Carl Thornton ('02, WW)

Wilson ('68, DB) and Patricia Thorpe

Janet Tinoco and Robert Pollard

Kent ('98, WW) and Joann Tipping

Thomas Tipsword

Dustin ('94, PC) and Sandra Tireman

William Tomasulo ('o1, DB)

Jeffrey ('o4, WW) and Susan Tomei

Joseph ('7o, DB) and Samantha Valla

Christian ('o3, DB) and Lauren Tougas

Massood Towhidnejad and Khandan Molavi
Peter ('8o, DB) and Rachael Townson

Nancy Tran-Horne

Ruth Triplett

Peter ('59, DB) and Linda Tufts

James Tuntland

Joseph Turner ('o5, WW)

Charles and Carolyn Unger

John and Darlene Unrue

Shirley Vaden

Ambrosio Valles

Seymour and Wilma Van Gundy

Donna and Jim Van Ness

Thomas ('81, WW) and Mary Van Petten

Robert ('83, DB) and Lori Van Riper

Court ('83, '88, WW) and Diane Van Sickler

David Vanstrom ('84, PC)

Dennis Vargas ('91, '98, DB)

Clyde and Florence Vierra

Frances Villaescusa

Anthony ('o7, PC) and Kim Villalpando

Joaquin ('79, DB) and Pamela Villarreal

Edward ('72, DB) and Mary Vogel

Scott ('8o, PC) and Melista Vogtritter

Timothy ('o5, WW) and Carol Vreeman

Robert ('87, DB) and Francine Wagensommer

Riley Walker ('o1, WW)

William ('74, DB) and Bobbi Jo Walsh

Anthony ('83, PC) and Elaine Walsh

Michael ('o1, WW) and Susan Walsh

Kevin ('78, DB) and Louise Ward

Ralph ('76, DB) and Charlene Washburn

Eric ('05, 'o6, WW) and Mei Watkins

Robert (' , WW) and Paula Watkins

Gregory and Lora Weaver

George and Lorraine Weick

Anthony and Diane Welch

Warren Weldon ('o8, WW)

Carl ('95, '96, WW) and Pong West

William and Marilyn Whalley

Sidney Wheeler ('o4, WW)

Stanley Whetstone

Glenn ('8o, WW) and Marcie White

James and Trudy White

William ('86, WW) and Penny White

Leslie and Stephen Whitmer

Timothy ('84, DB) and Marla Wieck

Lyle ('86, DB) and Karley Wigton

Stephen ('78, DB) and Maureen Wiles

Betsy and Michael Wilhelm

Charles and Linda Williams

Bruce and Ann Williams

Frankie and Patricia Williams

Jeffrey ('83, DB) and Elizabeth Williams

Steven ('8o, DB) and Kathy Williams

Eric ('94, DB) and Vickie Willis

Frank and Nancy Wilson

Emerson Wilson

Norman and Joan Wnuk

Mark Won ('86, PC)

Henry ('96, WW) and Tracy ('95, WW) Wood

Dennis and Brandi Wood

Patsy Wood

Gregory ('95, PC) and Kim Woogerd
David ('93, WW) and Laurie Wyndham Eiji Yoshimoto ('o1, DB)

Wayne ('62, WW) and Mary Young

Robert Zabel ('o6, WW)

James and Carol Zacha

Valerie and Raul ('84, DB) Zambrano

James Zeiler ('8o, DB)

Nancy Zeman

Stephen ('91, WW) and Jo Anne Zemanek

Julia and Hank Zirckel

Donald ('87, 'oo, DB) and Katherine Zwick

\section{Cadets}

\section{Corporations and Foundations}

Accenture Foundation

AMPAC ISP

Anaconda Veterinary Clinic

Andrews Accounting Solutions LLC

Applebee's

Arizona Aviation Supplies

ASIS Massage Education

Avalon Language Services

Aviation Solutions

Babcock Chiropractic Clinic

Berrien Becks Shopping Center

Blue Sky of Daytona Beach

Bob Evans Restaurant

Bonefish Grill

Borescopes R Us

$\mathrm{C} \&$ R Electrical Construction

Cameron Park Barbershop

Capponi and Foederer LLC

Chiesa Ranch

Colon \& Rectal Surgery Association

Cooper Photography

Crane Lakes Golf \& Country Club

Daily Grind Coffee House and Cafe

Daytona Beach Golf Club

Daytona Cubs

Peter Dellios D.D.S. PC

Dental-Craft Dental Laboratory

Dentistry By Schmid PC

Dolce Vita

Doors Plus

Chris Dudley Foundation

Dustin's Bar-B-Q

EACO

Experimental Aircraft Association

Ira E. Fender MD LLC

Fitness United with Nutrition

Flying Apple Ranch

Frappes North

Fraser Management Ship \& Mail LLC

Go-Kart City

Hilary and Ralph Goodwin Foundation

Houligan's/Ormond Wine Co.

HRYMFAXE LLC

Sharon K. Kauffman

KingChamp Books

William G. Kulekowskis PLLC

Lancer Wrestling Parents

David L. Lange Attorney at Law

Lindquist Realtors 


\section{REC OG N I T I O N O F G I V I N G}

\section{Cadets (cont.)}

Louie's Pizza House

Robert P. Luberto DO PC

Maxwell's Fitness Programs

McK's Tavern

Mentor Films

Michael's Yard Maintenance

Mr. Dunderbak's

Dean F. Murphy, M.D.

National Broadcasting Company

Northwest Painting \& Drywall

Nova Property Management

Olive Garden Restaurant

Ormond Lanes

Outback Steakhouse of Florida

Paws 'N Claws Veterinary Hospital

Peach Valley Cafe

Pilkington Dermatology

Pirates Island Adventure Golf

Pure Skin and Body Care

Red Lobster

Steve Ridder Basketball Camps

Ripley's Believe It or Not!

Riviera Country Club

RSC Equipment Rentals

Serendipity Facial Spa LLC

Hardy Smith Consulting LLC

Top of Daytona Restaurant

Trails Racquet Club LLC

United Technologies

Uno Chicago Grill

USTA Florida

Victor Cosmetic Family Dentistry LLC

Wicks 'N' Sticks

Wing House Bar and Grill

Wings, Pizza 'N' Things

WLC LLC

\section{Alumni and Friends}

Theresa Acosta

Billy ('81, WW) and Lavenia Acree

Clinsey Adams ('o2, '03, WW)

Judith Adams

Michael Adams ('89, DB)

Scott Adams

Raleigh Addy ('99, WW)

Ann ('o6, WW) and Frank Ade

John Adkins ('o7, DB)

John and Candace Adkison

Menas Akarjalian ('86, '97, DB)

Lee and Diana Aldrich

Jodi Allen ('o6, WW)

James ('92, DB) and Summer Allison

Mendel ('85, WW) and Monica Allison

Steven and Carol Anastase

Erik Andersen

Ivar ('92, WW) and Nancy Anderson

Dane Anderson ('ol, WW)

Geoffrey ('86, DB) and Patricia Anderson

Richard and Laury Anderson

Sean Anderson

Kenneth ('53, MC) and Kathleen Andrews
Sandi Andrews

Christine Ansel

Christopher Anthony ('o6, PC)

Timothy ('83, DB) and Lori Antolovic

Claude ('92, '03, DB) and Anna Archambault

Gerald and Paula Arneson

Richard ('86, WW) and Mary Arnold

Clifford and Mildred Ash

Edith Ashe

Jason Aspelund

Judith and Farrokh Assad

Dean Atanasoski ('99, DB)

Richard and Kristina Augustus

Donald Ausink

Norris ('84, WW) and Mary Aycox

Lucille ('97, 'o3, WW) and Robert Babcock

Rodney Babcock

Raymond ('87, DB) and Theresa Bacon

Richard and Gail Bagby

G. Laurence and Dana Baggett

Jesse Bagwell ('76, DB)

Thomas and Mable Bailey

Thomas Bailey ('55, MC)

Michael Balmert

Joseph and Peggy Baranowski

Christian Barbieri ('94, '99, DB)

David ('94, PC) and Mary Barbosa

Elayne Bardouche

David and Pamela Barnes

Jeffery and Marge Barnes

Susan and Daniel Barnhart

Mark Barnoff ('82, DB)

Ramon and Julia Barrales

Julio ('97, '99, WW) and Tammi Barreras

Raymond Barrett

Raul and Senaida Barriga

Mark ('95, WW) and Cheryl Barth

Eric ('93, '96, MC) and Robin Bartoletti

Richard Basile ('81, DB)

Surjit Basra ('o3, WW)

Roger ('94, 'oo, DB) and Amanada Battistoni

James and Teresa Baugh

Sue Baxter

Robert ('81, PC) and Deborah Bayley

Susan Bayley

Chester and Mary Jo Beach

Michael ('86, WW) and Karen Beale

Robertson and Theresa Beauchamp

Alyson Beausoleil ('o2, WW)

Frank Beber ('96, PC)

James and Adrienne Beck

Brian Becker

Carol Becker

Peter ('96, PC) and Regina Beckmeyer

Berrien and Kathy Becks

Raynald Bedard and Laurie Back

Emmanuel ('94, WW) and Annie Bediako

Farahzad and Sourour Behi

Leulseged Belayneh ('96, 'o7, WW)

Dawn ('87, DB) and Joseph Bell

Susan and Eugene Bencsik

James and Marguerite Benedict
Theodore ('82, '89, DB) and Deborah Beneigh

John Bente ('84, WW)

Timothy ('82, DB) and Lorraine Benton

Rudolph ('81, DB) and Patricia Bernal

Marc Bernier

Jennie Bethune

Stephen and Amy Bethune

Genevieve Biba

Richard Bicksler

Horace and Kathryn Bierer

Marty ('95, PC) and Iris Bischoff

Richard and Kristen Bishop

Richard and Adriana Bishop

Robert ('96, '97, WW) and Astrida Bishop

Daniel Bittner ('84, WW)

John Black ('64, DB)

Barbara and Damion ('o3, PC) Blackburn

Jonathan Blackwell ('o4, DB)

Brian and Jennifer Blake

Michael and Marianne Blake

Thomas and Kailee Blankenship

David and Coleen Blatt

Linda Bloom

Anton ('o4, DB) and Maryna Bogdan

David and Elizabeth Ann Boger

Bryan Boggs ('87, 'oo, WW)

Douglas and Carin Bohne

Hope ('o5, WW) and Craig Bonds

William and Rita Bonfitto

David Bonfitto

Michael and Mary Bonfitto

Robert and Louise Bonfitto

William Bonfitto

John and Maureen Bonner

Michael and Melissa Booker

Reece ('82, DB) and Tracy Bookout

Douglas and Louise Booth

Rafael Borges ('o6, 'o7, WW)

Gleamer Bost

Mike ('92, DB) and Laura Botkin

Joyce Boudreau

Dwight ('83, DB) and Bonnie Bowling

Clinton (' 80 , WW) and Janice Boyd

Lewis and Ruth Boyd

Bernd ('7o, DB) and Charlotte Boyt

Christopher Brady ('91, '97, WW)

Howard and Rose Marie Braman

James Braman ('93, WW)

Anthony and Dilena Branca

Samuel Branch ('o8, WW)

Richard and Sylvia Brandhorst

Brian Brantner ('o3, PC)

Kathleen and Bobby Brazell

Todd and Debra Breen

Alfred ('77, DB) and Carolann Brewer

Craig and Jessica Brickner

Maureen and Robert Bridger

Lori and Steven Brimhall

George ('96, WW) and Dawn Brindley

Sarah ('o8, DB) and Michael Brisson

Robert ('95, WW) and Patricia Brodwater

Robert ('02, WW) and Gail Brophy 


\section{REC OG N I T I O N O F G I V I NG}

Robert and Jean Brown

Barron ('98, DB) and Jennifer ('98, DB) Brown Joni and Harold Brown

Mary Jean Brown

Richard and Connie Brown

Thomas Brown

Lonnie Browning ('91, DB)

Kevin and Karen Brownrigg

La Vonta Bruch

Keith ('91, WW) and Susan Brune

Wayne Bubnick ('84, DB)

Bonnie Buckley

Robert ('o4, WW) and Linda Buckley

Thomas and Lynellen Bueter

Jorge and Luz Marisol Buitrago

Frank Bullock ('o6, DB)

Sarah and Bill Bullus

Kevin ('o1, PC) and Kristina ('oo, PC) Burns

Jeffrey ('o1, WW) and Lavonn Burrows

Timothy ('94, WW) and Joy Burson

Scott ('oo, 'o5, WW) and Elizabeth Burton

Owen ('94, DB) and Amy Busch

Frank and Diane Bushfield

Gerald Buss

Melville and Harriett Byington

Duane and Meldonna Byrne

Fred Caddell ('oo, WW)

Suzette and Robert Calabrese

Nancy ('72, DB) and Richard ('72, DB) Caldwell

J. Guy Callipari

Kathleen and Frank Campanaro

Donald ('83, WW) and Sylvia Campbell

Francis ('82, WW) and Jeane Campbell

Rita Campos

Lee Canning

Phyllis Capponi

Neal ('92, WW) and Susan Carbaugh

Thomas ('oo, WW) and Kristine Caristi

James and AnneMarie Carlin

Glenn ('94, WW) and Rae Carlson

Sarah Carlson-Ditmyer and Frank Ditmyer

Marge and Robert Carlton

Alan ('o5, WW) and Dinah Carmichael

Rachelle Carnes

Jennifer Carney and Christopher Wojton

Thomas Carns ('o6, WW)

Charles ('9o, WW) and K. Michele Carpenter

David ('91, DB) and Shelly Carpenter

Ricardo Carreras

Leonard and Laura Carroll

Christopher Carta

Michael ('95, WW) and Gina Carter

Brian Case ('o6, DB)

Boyd Casey

Dennis and Maresa Cassady

Peter and Carol Castellano

Viola Castellano

Mike and Cheryl Castello

John ('82, DB) and Susan Catania

Albert Catone ('91, DB)

Lisa ('98, DB) and Jackson Cavett

Ronald Caylor
Russell ('o4, WW) and Mary Celia

Bruce and Nancy Chadbourne

Leonid ('58, MC) and Elisabeth Chadovich

Donald and Judy Chandler

Emily Chappell

Trent ('82, DB) and Marilyn Chatman

Emil and Amy Chernicky

Francine and Larry Chidgey

Aroldo and Mary Chiesa

Jason Chokel

Adrienne Chong

Andrew Chriss

Scott ('o5, WW) and Karen Christner

Robert Churchill

Linda and Robert Cimikowski

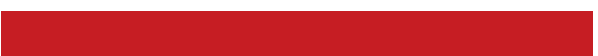

I am committed to the mission and vision of this university. I believe the educational programs we offer in math, science and engineering-based areas are the future of this country, and I want to support that. This university has given me personally so much more than just a career and has helped to shape me as a leader. It's really not much to ask to pass on to the next generation some of what ERAU has given me and my family.

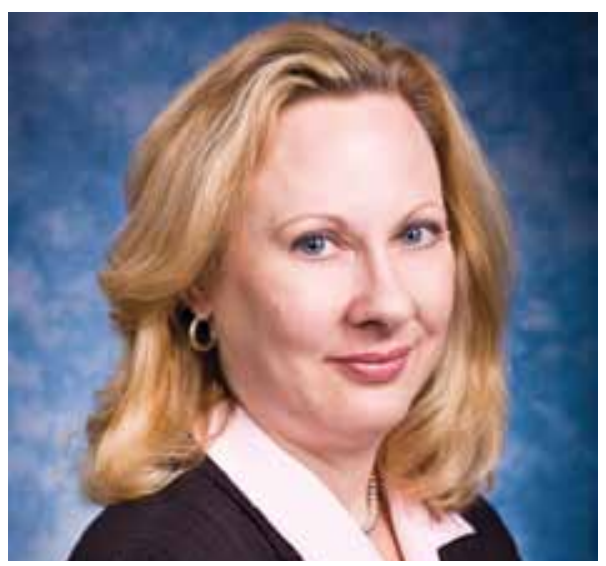

Christina M. Frederick-Recascino, Ph.D., vice president of Research at Embry-Riddle and assistant to the President, on her support of EmbryRiddle academic and research programming.

Robin Citron

Harry and Madelyn Clapeck

George ('76, DB) and Nancy Clark

Albert and Valerie Clark

Angela Clark

Cindy Clark

Ethan Clark ('o6, WW)
Michael Clarke and Deborah Solosie-Clarke William ('84, WW) and Michele Cleckner Michael Cleveland ('o8, WW)

Thomas Cline ('93, WW)

Angela and Eric Cobb

Perry Cockreham and Kathleen Hesse ('81, PC)

Robert ('79, DB) and Jacquelyn Coda

Charles and Irene Coggins

Michelle Cohen ('o6, DB)

Edward Cole ('86, DB)

Melody Aspeotes ('o4, WW)

Teakoe ('96, DB) and Sylvia Coleman

Richard Coleman ('75, DB)

Patrick ('oo, DB) and Angelica ('o2, 'o4, DB) Collins

Connie Colvin

Gregory and Ida Commins

Milton and Charlene Cone

Kevin ('o2, WW) and Amy Connelly

Gabriel Conrad ('o5, PC)

Agnes Conte

Matthew Conyers

Larry Cook

Pam Cooper

Susan Cooper

Harry ('72, DB) and Donna Coots

Kenneth and Lisa Corbin

Charles and Beth Corello

David Cornwell ('84, DB)

Paul Cotroneo

Terry and Sallie Jo Cowgill

James Cox and Arline Ott Cox

Jon ('84, DB) and Michelle Cox

Melissa Cox

Randolph Cox

Michael Crass ('o2, WW)

Dorothy Crawford

Marilee Creelan

Victor and Frances Cresenzo

Fran Cresser

Henry ('62, MC) and Angela Cressman

Burnell and Suzanne Crist

James Crockett

Elizabeth Crone

Ethan Croop ('o6, DB)

Steve Cross

Ernest and Laura Crownover

Mike Crozier

Rande and Celia Cruze

Noah Csortan

Calvin ('99, WW) and Zenaida Culp

Mathon and Evelyn Culpepper

David and Karin Culter

Douglas Cumins ('98, PC)

John and Joan Curran

Timothy Curtis

Walter Curtis

Joyce Cutts

Cheryl and Frank Dadabo

David ('82, DB; '88, WW) and Linda Dailey

Tony and Juli Dalton

John ('73, DB) and Barbara D'Angelone

Pamela Daniels ('oo, 'o1, DB) 


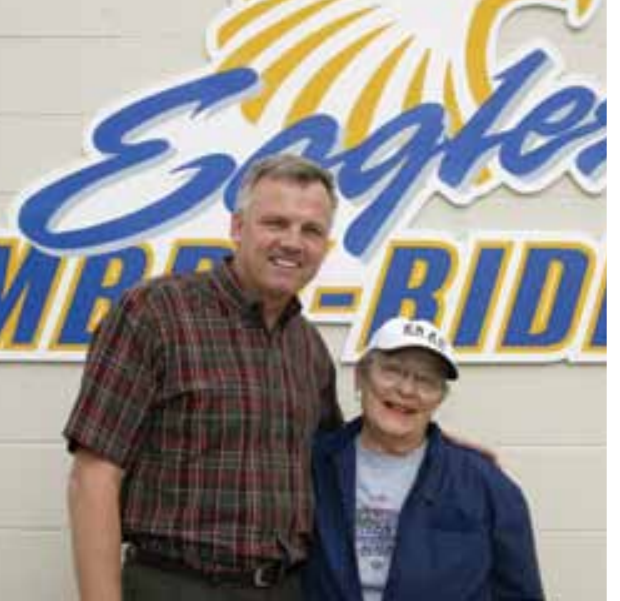

A portion of Dr. Steve Sliwa's gift will be added to the Kenneth J. and Shirley Sliwa Memorial Endowment, honoring Dr. Sliwa's parents who were great fans of the baseball team. Shirley Sliwa, pictured here in April 2005 with Athletic Director Steve Ridder, was a mainstay at Eagles' games, rallying the team with her trademark ringing of the cowbell.

\section{Blue \& Gold Gala} Raises $\$ 105,000$

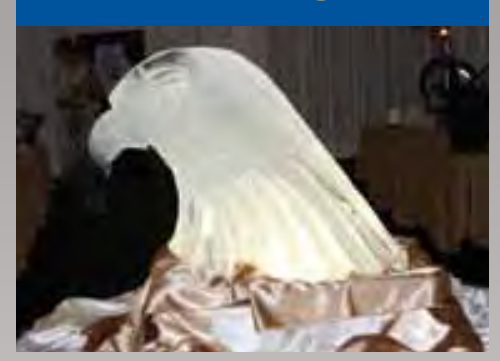

Capping off a great 2008-2009 season, the Embry-Riddle athletics program at Daytona Beach Campus raised $\$ 105,000$ at its fifth annual Blue \& Gold Gala.

Over 350 gathered at the annual fundraising silent and live auctions to support the athletics program. The proceeds from the event will support student-athlete scholarships primarily, but will also provide resources for equipment and operations to enhance the overall student-athlete experience at Embry-Riddle.

\section{Cadets (cont.)}

Andrew D'Arcy

Warren and Carol Darrow

Nathan Day ('99, WW)

Susan Day

Gary ('79, DB) and Debra Dayton

Carolina De Carvalho ('o5, DB)

Ricardo and Helena De Carvalho

Daniel and Margaret De George

Mark and A. Lynn De George

Carl Dean

Arthur and Dianne Deardorff

M. Bruce and Norma DeBord

Thomas and Jana Deery

Brian Dees ('99, DB)

Thomas ('o1, WW) and Angela Defatte

Robert ('83, DB) and Bernadette Degennaro

Mary Jane Deighan

Geno Del Boccio

Rachelle Del Boccio

Patrick and Janet Delaney

Robert and Phyllis Delaurentis

Allison Delizia ('o3, DB)

Anthony and Mary Ann Dellavechia

Peter Dellios

John and Jean Dell'Olio

Stephan and Sandra Dembinsky

Jonathan and Deanna Demoss

Ernest and Christine Desimone

Faith and Richard DesLauriers

Fred and Denise Dettmann

Jamie and Robert DeVault

Richard ('82, DB) and Jill Devins

Ann Devitt

Leonard and Katharyn DiBenedetto

Gary Dickinson ('82, DB)

Barbara Diebolt

Arnold ('95, DB) and Laura Discher

Floyd ('99, WW) and Lisa Dissinger

Joann Dixon

Patrick ('76, DB) and Kee Dizzine

Andrew ('95, PC; '07, WW) and Brenda Dobis

Richard Dodd and Katherine Preston Dodd

Neil ('89, WW) and Kim Doh

Mary Dohr ('81, WW) and Craig Goheen

John and Karen Domme

Garry and Mary Doncourt

Guy ('82, PC) and Jennifer Doot

Debra and Glen Doyle

Lisa Doyle ('86, DB)

Jacqueline Drumbore

Adrian Drummond ('o5, DB)

Chad Drummond

Skip ('o7, WW) and Victoria Du Rand

Kevin Duda ('o1, DB)

Martin Dudeck ('88, DB)

Chris Dudley

Neil ('88, DB) and Dara Duggan

Florence Duncan

Matthew ('o4, WW) and Deborah Dunfee

Gregory ('9o, PC) and Roberta Dunn

Luckey Dunn and Wendy Myers Dunn
Steven ('95, DB) and Betsy Durnin

Richard and Mary Jo Dussault

William and Nancy Ealy

Elizabeth Eastlack and Michael Shaw

Bill and Joyce Eavey

Donald ('75, DB) and Marcia Eberlein Richard ('o7, WW) and Paula Ebhardt Randy ('94, WW) and Caroline Eckley Rob Eichelbaum ('o1, DB)

Raymond Elkin

Gary ('83, DB) and Carolyn Ellington

Crystal and John Ellis

Michael and Patti Ellis

Gerald Ellsworth

Von ('o6, WW) and Tara Elmegreen

Jay Enfield ('o2, WW)

Thomas England ('oo, DB)

Ralph Erb ('81, DB)

Thomas and Elizabeth Eriksson

John and Ruth Esposito

Burton Etheridge ('82, WW)

Steven ('91, WW) and Karen Ettien

Jason ('o2, DB; 'o6, WW) and Elizabeth Evans

Merial Everett

Vincenza and Dominick Falletta

Michael Farrell

Michael and Dorothy Faughnan

Brett Faulkner ('94, WW)

Randle and Barbara Faunce

Roy and Patricia Fedelem

Barry ('o8, WW) and Danielle Fegan

Jeffrey ('oo, DB) and Wendy Fejfar

Ira Fender

Samuel and Constance Feola

Bill and Karen Ferguson

Peter ('76, DB) and Tracy Ferguson

Robert ('78, DB) and Melissa Fernandez

Bruce Ferretti ('88, DB)

Richard ('oo, 'o2, WW) and Donna Fescoe

Mary Ann Fethke

Katherine Field

Keith Fike ('97, WW)

Adolph ('74, DB) and Linda Finder

Brian Finifter ('o5, DB)

Mark Fitzsimmons ('oo, DB)

Don and Erlene Fivecoat

Gerald Fleming ('o3, WW)

Jerry ('93, WW) and Patricia Fletcher

Gretchen Flint

Jose ('03, 'o5, WW) and Mary Flores

Harry Foden ('54, DB)

Diana Foederer

Terrence ('89, WW) and Josephine Fogarty

Rachel Folsom

James and Catherine Forester

Anthony and Renee Formusa

Timothy Fortes ('8o, DB)

Tonia Fortner

Terry ('97, WW) and Julia Foskey

Lloyd ('83, DB) and Mary Foss

Warren ('81, DB) and Carol Foss

William Foulk ('85, DB) 


\section{REC OG N I T I O N O F G I V I N G}

\section{Cadets (cont.)}

Dixie Fradel ('82, WW)

Maria Franco

Shirley ('92, DB) and Mark Franko

Meryl Frapper

Myles Fraser

Bill French

Charles ('88, DB) and Deborah Friday

Richard and Bonnie Fronauer

Mark and Jane Fugler

William and Louise Funcheon

Richard (' 78, DB) and Mary Furman

Virgina Furrow

Beverly Gabbert

Thomas ('77, DB) and Mary Galbraith

Douglas Galeai

Jacinta Galeai

Kevin and Lisa Gallacher

Matthew Gallo ('o8, WW)

Joslynn Gallop

Walter Gamin

Sathya Gangadharan and Manjula

Sathyanarayan ('96, DB)

Annamarie ('o3, DB) and Pablo ('o2, DB) Garcia

Matthew Gardner

Keith ('83, DB) and Linda Garfield

Raymond ('99, WW) and Annette Gaskill

Matthew Gaskins ('o3, DB)

Marion Gaston

Shannon ('94, DB) and Michael Gavornik

William and Linda Geiger

Christine Gentile

Edward and Anita Gentile

Mark ('oo, WW) and Susan Georgeff

James ('84, PC) and Shirley Gessner

Donna ('o3, 'o8, DB) and James Giambra

Frankie ('83, DB) and Rheta Gibbs

Stephen Gibbs ('75, DB)

Rene ('84, DB) and James Gibson

Trace Gieser

Gary and Betty Gilbert

Michael and Katherine Gillogley

Tom Gladding

David and Eleanor Glaysher

Keith and Maxine Glazier

Dale and Joy Gloer

David and Paula Gluch

Robert and Janice Godfrey

Karl and Tiffany Goettl

William ('97, WW) and Deborahline Goggins

Anna ('84, 'oo, WW) and William Gohranson

Barbara Golbach

James ('go, WW) and Stella Golliday

David and Gale Gomes

Kevin ('81, DB) and Patricia Good

John (' 76, WW) and Jane Goodnight

Hilary and Ralph Goodwin

Thomas ('o7, WW) and Michaela Gordon

Thomas and Carole Grady

Susan and Fred Grassin

Bradford ('93, DB) and Katherine Green

Dustin Green ('o6, DB)
Shannon and Melissa Gregory

Margaret and Douglas ('84, WW) Grewing

Harold and Dorothy Griffin

Dale and Veronica Griffis

Barry and Alice Grogan

Thomas and Jana Rae Grose

John ('97, WW) and Helene Gross

Kenneth and Karen Grove

Karen Grover

Betty Grozier

David and Barbara Guhlke

Jeff ('o7, WW) and Donna Guiler

Larry Hagan ('02, WW)

Hamilton and Rahna Hagar

Lynn Hagstrom

Brent and Blanca Haladyna

Robert ('87, WW) and Henri Hale

Luz and Anthony Hall

Ronald Hall

Ronnie and Debbie Hall

Kenneth ('56, MC) and Vivian Hamann

Bruce ('84, DB) and Patricia Hamilton

Arayna Hamilton ('o1, WW)

Elena Hanna

Stephen ('o7, WW) and Reginia Hansford

Sherman and Marjorie Hanson

Nagruk Harcharek

Douglas and Joni Harder

J.M. ('86, '93, WW) and Bonnie Hardwick

Hugh Hardy ('99, WW)

Stewart and Rosa Harkness

Timothy and Elizabeth Harmle

Donald Harper ('o2, DB)

Joshua Harper

Thomas ('02, '03, WW) and Kasey Harr

Chrystal Harris ('05, WW)

Darren ('95, DB) and Michelle Harris

Marian Harris

Sally Harrison

David ('76, DB) and Pamela Harsanyi

Frank Hartl

Jill ('95, DB) and Jeffrey Hartman

Allan ('og, PC) and Amy Hartung

Esa-Petteri Harvela ('99, PC)

Joseph ('97, WW) and Joan Hasenmayer

Walter Hawkins ('77, DB)

Mitchell and Julie Hawkins

Antony ('02, DB) and Amy Haworth

Michael Hayden ('93, WW)

Barbara and Robert Hayes

Don Hazell and Jennifer Hagman Hazell

Roger ('83, DB) and Catherine Headley

John Healy

Angela and Lewis Heaster

John ('81, '86, WW) and Linda Hedly

Sara Heffelfinger ('o1, PC)

Robert and Amy Heitman

Nathan and Lisa Heller

Mark Hemink ('77, DB)

Rodney and Herminia Hemmitt

Erin Henderson ('05, DB)

Barbara and Robert Hendrickson
Thomas ('74, DB) and Eileen Henion

Richard and Sandra Hentz

Bryan Hermann ('oo, DB)

Dennis and Julie Hermerding

Guillermo Hernandez ('96, DB)

Richard ('92, DB) and Teresa Hernandez

James ('86, PC) and Katherine Herr

Ralph and Nancy Hess

Herbert ('72, DB) and Rosemarie Hiers

Timothy ('89, PC) and Carolyn Hiestand

Christopher ('o8, DB) and Nancy Higginbotham

Christopher Higgs

Sandi Higgs

John and Patricia Hilgenberg

Randy ('o4, WW) and Deborah Hillenburg

Rodney and Charlene Hillis

Jennifer Hinebaugh ('o2, WW) and

Michael Mulrooney

William and Barbara Hinebaugh

James and Leilani Hoben

Phillip ('o4, DB) and Danielle Hoden

Brian ('87, PC) and Heather Hoffman

Steven ('87, WW) and Brenda Hoffman

Timothy and Alisa Hoffman

John ('88, WW) and Lucinda Hoffmaster

Larry and Darlene Hofmann

Jenifer ('93, WW) and Patrick Hogan

Thomas Hogan

Arthur Holcomb ('84, WW)

William ('94, WW) and Gretchen Holcomb

Corky and David Holley

Charles ('83, '85, WW) and Marian Holmes

Christopher ('99, DB) and Amy Holtzman

David Hoobler

William ('95, WW) and Engrid Hooper

James and L. Catherine Hoover

Stephen and Patricia Hoover

Peter and Cynthia Hopfe

John Horton ('98, DB)

Richard ('o2, WW) and Dina Houston

Frederick and Velva Hovey

Christopher Howard ('o7, WW)

Wilma Howard

James ('91, WW) and Mary Howell

Kenneth Hoyt ('75, DB)

Ruth Hubchik

Richard and Barbara Huber

Eugene and Margaret Hughes

Zachary Hughes ('o4, WW)

Marian Hulecki

James and Patricia Hunt

Robert ('75, DB) and Marilyn Hunter

Robert and Virginia Huson

Todd and Patti Huson

George and Maureen Hutchinson

Theodore and Lynda Hutchison

Mikko Huttunen ('89, DB)

Sal Iamarino

Mike Iasparro

Nicole Imbrogno

Richard ('9o, '95, WW) and Elizabeth Ingraham Gordon Isaacson ('o6, WW) 


\section{REC OG N I T I O N O F G I V I N G}

Linda Isabell

Mohamed ('83, DB) and Rubina Ishaq

Paul ('71, '72, DB) and Linda Issler

Camille Jackson

Curtis and Elaine James

David Jaworski

Carlton Jenkins ('98, WW)

Barbette Jensen ('99, DB) and Michael Burd

Eric ('93, DB) and Bethany Jensen

John and Kelly Hanson

Jeffrey and Sybil Jewell

Reid ('71, DB) and Sandra Jewett

Joan and Lloyd Jiminez

Big John

Charles ('o3, WW) and Paula Johnson

Douglas and Corliss Johnson

Douglas ('88, '9o, DB) and Christina Johnson

Gordon Johnson

Jerome ('89, WW) and Cynthia Johnson

Leroy and Sara Johnson

Timothy ('98, WW) and Terry Johnson

Virginia Johnson

Benny and Christina Jones

Gayle ('9o, WW) and Gary Jones

Terry ('o5, WW) and Norma Jones

Andrea Joseph

Guy and Suzan Joshu

Robert and Kayren Jost

Roy Juda and Patricia Herrman Juda

Angela and Zoltan Kalan

Melvin and Florence Kalb

Danny Kalenowski ('o4, WW)

Frank ('65, DB) and Leona Kallay

Frederick ('84, '88, DB) and Kari Ann Kalloo

Stanley and Beverly Kaltnecker

John Kanalas ('87, '9o, DB)

Thomas and Kathy Karnezis

Steven ('8o, DB) and Roberta Kassan

Shannon Katt ('92, PC)

Sharon and Dan Kauffman

Joseph and Nora Kaus

Paul and Erin Keating

Ira ('71, DB) and Mary Ellen Keiter

Chad and Jennifer Keller

Francis ('87, WW) and Denise Kelley

Anthony ('98, WW) and Audrey Kelly

Danielle Kennedy ('99, DB)

Shannon Kennovin

John and Joan Kepner

Amber Kerr

Donna and Stephen Kerr

Henry and Maria Kesselring

John Khayata ('89, WW)

William and Barbara Kiger

Eric ('95, DB) and Alina Kimler

Angela King

Stuart and Lauren Kingsbery

Stephen ('98, WW) and Karen Kingsbury

Kenneth Kirchner ('o8, WW)

Sherridan and Nitasha Kirk

Margaret Klemm

Thomas Klenke ('91, '92, DB)
James Klingele

Rudolf and Patricia Knabe

Michael ('o3, WW) and Peggy Knebel

Raymond ('84, DB; 'o7, WW) and Kathy Knispel

Clifford and Karen Knitter

Robert and Joyce Koch

Sandra Kochendorfer ('o3, WW)

Jarret Koenning

Joan Kooken

William and Charlotte Korff

Scott Korrant

Harold ('62, '63, DB) and Joan Kosola

Andrew Kramar ('o3, PC)

David ('91, PC) and Renee Kreun

Louis and Kathleen Kubilus

Charles and Mary Kucera

Donald and MaryAnne Kuelbs

William Kulekowskis

Jerome and Carole Kulesia

Judi Kurth

Michael Kuss ('o8, DB)

Jennifer and William Labonte

Vito and Sandra LaCassa

Brian ('83, DB) and Sue Lachapelle

Michael ('9o, DB) and Jennifer Ladeau

James ('67, DB) and Virginia Ladesic

Kristen and Paul ('o1, WW) Lalumiere

Mathew and Emily Lamonica

Edward and Kathleen LaMontagne

Shawn and Gisela Land

Eileen Landis-Groom and Richard Groom

Scott ('88, PC) and Ann Landschoot

Tharon ('o4, WW) and Vivianne Lane

Paul ('84, DB) and Joyce Lang

Richard ('84, DB) and Suzanne Lang

David Lange

Gerold ('66, DB) and Mary Sue Langendoerfer

Charles ('o2, WW) and Marjori Langhoff

Everett ('43, MC) and Joan Langworthy

Scott Larson

Neil and Carole Lasky

Earle ('86, WW) and Maria Lauderdale

John Laursen

John and Helen Lauterbach

Kurt Lawson ('93, PC)

Michael and Dawn Laylock

James and Julianne LeBlanc

Linda and Richard Lecates

David ('o8, WW) and Kelly Leckelt

Jim and Deborah Ledbetter

Bonnie Lee

Kai Lee

Christine ('o7, WW) and Joel Legawiec

Lee and Gladys Lehman

Dale and Maryann Lemery

Tim and Janet Leonard

William ('91, WW) and Elizabeth Lewandowski

Kathleen ('9o, WW) and Michael Lewis

Ellie Liebeck

Kyle Lindemer ('o6, WW) and Lisa

Lenertz-Lindemer

Gregory ('o6, WW) and Lonna Lindmark
Fred and Karen Lindquist

Willard Lineburg ('59, MC)

Ken and Barbara Link

Jianhua Liu

Karen Lloyd ('82, DB)

Olivia ('oo, WW) and Maurice Lloyd

Terrance ('96, 'o4, DB) and Yong Sun Lloyd

David and Betty Lockhart

Mary Lockwald

Raymond ('7o, DB) and Deborah Loehner

Joanna Loehr

John ('o1, WW) and Dawn Logiudice

Gerard Lombardo

Guilherme Lopes ('og, PC)

Jocelyn Lopez

Johnny and Sue Lopez

Julian and Wenceslaa Lopez

Rolando and Jennifer Lopez

Zalo ('43, MC) and Ofelia Lopez-Garzon

Peter and Yolanda Loprete

Linda Lorimer ('99, '02, WW)

Michael ('oo, DB) and Jennifer Lorino

Christine Loughney

Cheryle Love

Shelley and Cathy Lowry

Robert Luberto

John Lucko

Marc and Jacqueline Luedtke

Margaretha Lum

Rachael Lund ('o6, DB)

Courtney and Hector Luque

Paula ('96, DB) and Paul Lutton

Douglas and Christine Lynch

Thomas and Brenda MacDougall

Maureen Macellaro

John and Margie Machado

Roderick and Monica MacIntyre

David ('9o, DB) and Leah MacNellis

John ('83, WW) and Suszann Magner

Pamela Maher ('83, DB) and Gregory Beu

Richard and Arlene Maicon

Harry ('77, DB) and Kim Maier

Robert and Patricia Malecki

Michael Maleki ('o8, DB)

Manji Mamven ('05, DB)

Patricia and George Manning

Sylvia Manor ('85, WW)

Richard ('oo, MC) and Bella Mansfield

Arcangelo and Kathleen Mariano

Joseph ('78, DB) and Katie Marley

Nadine Marquez

Ramona Marquez

David Martin ('94, WW) and Kim Sheppard

Lucas Martin ('02, DB)

Sharon Martinson ('o2, WW)

George and Mary Mas

Denise Mason ('o7, WW)

Steven and Cindy Masotti

Malcolm Massung ('78, WW)

Michael and Deborah Masters

Chester and Frances Masztak

Craig ('97, DB) and Jamie Maternowski 


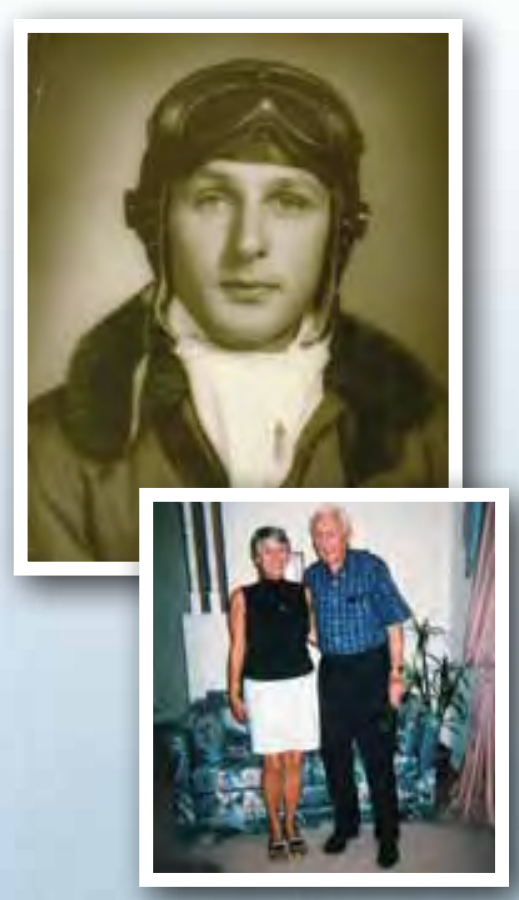

Lee Prescott, who fondly recalls

flying as a young girl with her father in a Stearman (like the one pictured below), made a fitting tribute to her father with the establishment of the Lawrence

E. Nix Presidential Endowed Memorial Scholarship.

\section{Flights with father inspire gift for aspiring pilots}

Deborah Lee Prescott's happiest childhood memories of her father, Lawrence Nix, always involved flying.

"It was the one, great overarching love of his life," Prescott recalls. She remembers him studying huge aviation manuals and poring over maps that draped over the dining room table.

"My father's dream was to fly commercial planes," Prescott recalls, "but as a child from a poor family, the best possibility to become a pilot was to join the military."

A career Air Force bomber pilot, Lieutenant Colonel Lawrence Nix flew B-26, B-47, and C-118 aircraft during active duty and Lear and Gulfstream aircraft as a civilian for 14 years following his military service.

In memory of her father who died in 2007, Prescott, an associate professor of English at Palm Beach Atlantic University, has established the Lawrence E. Nix Presidential Endowed Memorial Scholarship. Her hope is that her gift will allow others to achieve their dreams of becoming pilots-something her father, who grew up in the Great Depression, made many personal sacrifices to do.

Prescott's gift, while serving as a loving tribute to her father, is also a celebration of the joy that flight can bring to those who pursue it.

"As a young girl, the best times I ever spent with my father were in flight." Prescott recalls. "I flew as my father's co-pilot in many different small planes, but the greatest of these times together was acrobatic flying in a Stearman." 


\section{$\longleftarrow$ R E C O G N I T I O N O F G I V I N G $\longrightarrow$}

\section{Cadets (cont.)}

John and Judy Mathis

Jennifer Matthews ('o2, DB)

Kennith Matthews ('oo, MC)

Linda ('96, WW) and Michael Matthews Keith Mattingly

David ('94, WW) and Kimberly Mattson

Dustin ('99, PC) and Melissa May

Thomas May and Debra Carnes May

Wendell ('97, WW) and Darla May

Kenneth and Mary Jane Mc Bride

Judith Mc Clory

Patricia McAllister

Allison McAuliff

Robert ('93, WW) and Valerie McCarthy

William and Edna McCarthy

Paul and Donna McClay

Terry and Mary McCool

Miles ('86, WW) and Karen McCormack

Dariel ('88, WW) and Jayme McCourt

Almax ('92, WW) and Perla McCoy

Paige McCrory

Samuel McCully

Dwight McDonald ('91, '92, DB) and Donna Rodrigues-McDonald

Patric McElwain

Donald McGill and Doris Lethbridge-McGill

Myron McKenzie

Monte and Lillian McKinley

William McKinney ('79, WW)

Michael ('oo, WW) and Jo Ann McLeer

William and Misuza McManus

Benjamin ('93, WW) and Michelle McMath Jeffrey ('o5, DB) and Hollee McNamee

G. Neil and Donna McNaughton

Thomas ('86, WW) and Jacklynn Meadows Edward Medina

Edward and Susan Meduvsky

Martin ('89, 'o1, WW) and Patricia Melton

Mitch and Katie Mentor

Richard and Kathy Mercurio

Jill ('o2, DB) and John Meridith

Lui Merlino

Gary ('9o, WW) and Cathy Jo Merrill

Jerry ('89, WW) and Kathleen Merritt

Werner and Judith Meserth

William ('o4, WW) and Wendy Mesloh

Peter Meyer and Katrina McCormick-Meyer

Bernard and Barbara Meyer

Brian ('82, DB) and Ana Meyer

Cindy Meyer

Randell ('89, WW) and Barbara Meyer

Eric and Charlotte Meyers

Chris (' $78, \mathrm{DB})$ and Yvonne Michalakis

Brian ('92, WW) and Carey Michel

Michael and Julie Miglioranzi

James ('o5, WW) and Sunny Mihalick

Winfred ('92, WW) and Celia Mihill

Joseph ('44, MC) and Pearl Miles

Bonnie Miller ('9o, WW)

Del and Susan Miller

Dennis and Bernadette Miller
Gerald ('o1, 'o5, WW) and Amy Miller

Hugh and Muriel Miller

Matthew Miller ('94, DB)

Sanford and Mary Miller

Thomas ('58, WW) and Carol Miller

Anthony ('o7, WW) and Krista Millhouse

Ethan Mills Grassin ('o6, DB)

Susan Mills

Nicholas Mingione ('oo, DB)

We are pleased to grant a gift of $\$ 50,000$ to Embry-Riddle to be used in support of Professor Tarek El Dolkor's research program addressing the issues relating to the interface of automotive vehicle controls. We appreciate this opportunity to work with Embry-Riddle toward the successful development of this technology.

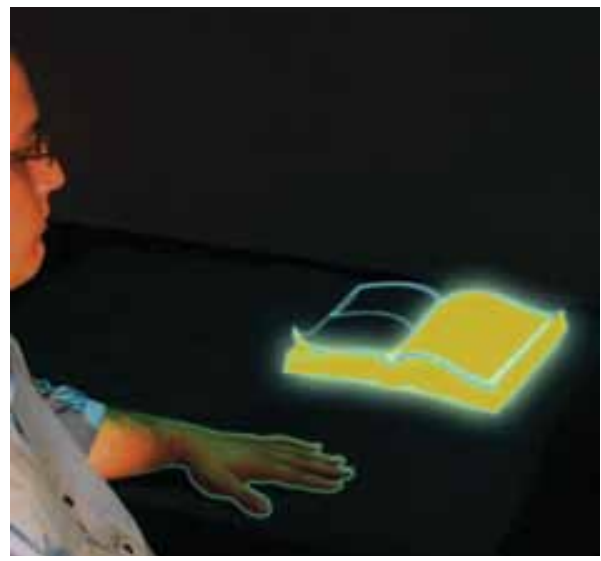

Yoshiaki Sakagami, president of Honda Research Institute USA, on Honda's gift to support Machine Vision Lab research (pictured above) at EmbryRiddle's Prescott Campus.

Alan ('69, DB) and Rosemary Mittelstaedt Thomas Molinari

Russell Moll

Evert-Jan Moller ('99, DB)

Mark ('99, WW) and Mary Monaghan

Darrell ('94, WW) and Geri Monday

Wilma Mongold

Joseph Montenaro

Vincent ('87, DB) and Amy Monteparte George and Dorothy Montgomery

Roy ('89, WW) and Diana Montgomery

Ian Moore ('o5, PC)

Janice Moore

Kelly ('98, PC) and Eric ('98, PC) Moore

Michael and Nance Moore

Juan Mora ('o6, WW)

Lauren Moran
Sean Moreau

Elizabeth Morejon

Katrina Morgan ('o8, DB)

Steve ('o4, WW) and Sherry Morgan

Bradley ('91, DB) and Kathleen Morgenroth

George Morrison

James Morrison

Shaun Morrow and Claudia Bonsignore William ('73, '75, DB) and Carol Morse

Drew Moses ('o7, DB)

Christopher Mosher

Nicole Mosley

Nicholas Mostert ('87, DB)

Jeffrey ('99, DB; 'o7, WW) and Lauren Mrozinski

Rae Ann Mulligan

Gary ('87, WW) and Darcy Munroe

Jennifer and Eric Munzberg

Michael Murdock ('oo, WW)

David and Terri Murillo

Charles and Laura Murphy

Dean Murphy

Dennis and Barbara Murphy

James and Barbara Murphy

Joel Murphy ('o6, WW)

Walter and Christina Murray

Christopher Muth ('o6, WW)

Steve ('74, WW) and Sharon Nagy

George ('81, DB) and Lori Nalley

Terry Nash and Melinda Chandler-Nash

Mahmood Navidi ('78, DB)

Henry ('07, WW) and Pollyanna Neely

David ('o1, WW) and Kim Nelson

Robert ('oo, WW) and Jane Neuharth

Robert ('8o, DB) and Crystal Newell

Andrew and Jennifer Newitt

Ray and Patty Newton

Freddie ('84, ' 98 , WW) and

Marilyn ('98, WW) Nicholas

Timothy Nichols ('91, WW)

Edward and Valerie Nicholson

Richard and Gail Nickel

Pamela ('91, PC) and Chad Nimrick

Victor Nitu

Roger ('82, DB) and Carol Noble

Jeffrey and Susan Noll

Gini and Daniel Norgard

Eugene and Janet Nothnagel

Trish ('7o, DB) and Steve Nowicki

Bruce and Barbara Oberst

David ('o8, WW) and Cynthia O'Brien

James ('83, '86, WW) and Veronica O'Brien

Guy and Corazon O'Connor

Edmund ('o4, DB) and Eunice ('o5, DB)

Odartey-Williams

John ('88, WW) and Mary Ann O'Donnell

Marcella O'Flanagan

Craig ('84, DB) and Kathleen Ogan

Seward ('84, PC) and Maria Ogden

Christopher ('96, DB) and Joy O'Gwen

Edward and Angela O'Hair

Julie Ohlahausen 


\section{RECOG N I T I O N O F G I V I N G}

\section{Cadets (cont.)}

Deon and Carolyn Ojan

Timothy O'Leary

Daniel Ortega

Tony and Carmelita Ortiz

Brian ('88, WW) and Maria Osborn

Clinton Ostler ('oo, PC)

Nancy Ostrander

Warren and Judy Overstreet

Lief and Patience Owens

John ('91, WW) and Linda Pacitti

Matthew ('99, DB) and Megan Paddock

Thomas and Sandra Padgett

John and Marjorie Page

Michael and America Page

Virginia Page

Lawrence ('88, DB) and Melanie Palma

James ('o3, WW) and Julia Palmer

Mehul Pandya

Thomas ('74, DB) and Julia Paradis

Allen ('81, DB) and Mary Parker

Donald and Raellene Parker

Michael Parker

Roy ('73, DB) and Abby Parkinson

Don and Karyn Parks

Matthew ('83, DB) and Roseann Parlier

John ('83, DB) and Donna Parrish

Nader Parsia ('77, DB)

Mike Patitucci

John and Karen Patton

Thora Paul

Bradley Pauley and Chadney Duncan-Pauley

Margaret Pauley

John and Kathleen Pavkov

William and Nancy Pavkov

Byron Payne

Daniel and Paige Payne

William Pearson

John ('84, WW) and Dianna Pecic

Scott Peirce

Alyssa Peralta

David Percy ('88, DB)

Eugene and E. Elaine Pereboom

Scott ('o1, WW) and Barbara Pernett

David and Barbara Perryman

Joseph and Barbara Perugini

Joe and Carolyn Peters

Philip and Arlene Peters

Brock and Kathryn Peterson

Eric Peterson

Harvey ('87, WW) and Georgia Peterson

David ('85, PC) and Rosa Petrella

Robert ('o4, WW) and Carol Petrillo

Thomas ('72, DB) and Patricia Pettit

Jeanette Pfalzgraf-Norris and Jerry Norris

Tiffany Phagan

Charles Pharis

Joseph ('97, WW) and Lisa Phillips

Donald and Josephine Phillips

Glenn ('85, DB) and Brendanne Phillips

John ('9o, '92, DB) and Ann Phillips

Curtis (' 92, WW) and Laura Phipps

Carmine Picciano
Morris ('89, WW) and Terry Pickel

Dwight and Maureen Pickett

John ('o1, DB) and Michelle ('o1, DB) Picklesimer

James ('81, WW) and Suki Pierce

Peggy Pierce

Steven and Laura Pierce

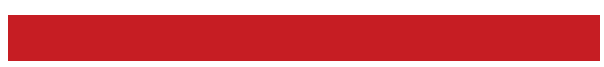

The TBM Owner and Pilot Association Board (TBMOPA) decided that supporting students in aviation education would fit with its goal to allocate money in an avenue that connected the owner's group to the aviation community at large. EmbryRiddle Aeronautical University, being the premier aviation institution, should be the instrument [to achieve this goal]. Supporting a worthy aviation student is a great investment in the future of aviation. TBMOPA plans to continue scholarships to ERAU students.

Tom Evernham, Chairman of the TBM Owner and Pilot Association, on why the organization established the TBM Owners and Pilots Association Scholarship Fund, designed to provide term scholarships to students in the Aeronautical Science and Aircraft Maintenance programs.

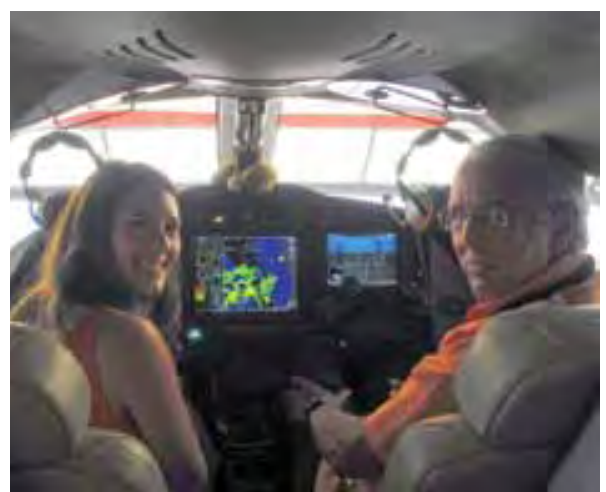

Tracy Forrest (right), a member of TBMOPA, gets ready to take off with scholarship recipient, Ashley Hoff.

David Pilkington

Kevin ('o8, WW) and Deena Pinto

George Pittman

Carl ('97, WW) and Lisa Pizzo

Michael ('76, DB) and Melissa Planert

John and Janet Platosz

Christopher Plumb

Loren and Lois Pohl

Frederick and Barbara Pole

Eugene and Barbara Polk
Richard ('76, WW) and Olive Pollak Edward Poon

Darlean and Richard Pope

Derik Poppino ('o7, WW)

Curtis ('72, DB) and Mutsuko Poree

Nicole Potter ('o7, PC)

Rissa Potter

Brian ('92, DB) and Shannon Poulston Jann ('oo, WW) and Carla Powell

Beverly Pratt

John and Rebecca Pratt

Lynn and Richard Prine

Ruthann Puccinelli

Edison and Mariela Puentes

Efra and Elsa Puentes

Julio and Clara Puentes

Yuler and Maria Puentes

Frederick Pulve

Michael and Maria Pyle

Caroline Pyne

Glen Pyne

Andy Quintana

Rami ('64, DB) and Antonia Rabin

Katy Rachman

Thomas ('64, WW) and Glenda Rackley

Gil Radassao

Larry ('o5, WW) and Lisa Raines

Ronald Rakos

Michael and Lisa Ramirez

Jesus ('o6, WW) and Maria Ramos

Kenneth and Lisa Ramsey

Nickolus ('84, WW) and Sylvia Rasch

Charles and Pamela Ratcliffe

Deborah Ratcliffe

George Ratcliffe

W. Keith and Meredith Rattay

George Raven

Janet Raven

Anne Ravey

Karen Raviotta

John Red ('o4, PC)

Luke Rederus ('o4, PC)

Mark Reed and Carrie Straka Reed

James ('97, '98, WW) and Ana Reeder

Marvin Regensberg ('98, WW)

William ('72, DB) and Eugenia Rehrmann

Jeffrey and Susan Rein

George ('44, MC) and Joanne Reisinger

Berwyn and Helen Remily

Scott ('o8, WW) and Martina Remington

Herbert and Frances Restmeyer

Heather ('96, PC; 'o8, WW) and Richard Reuter

Mahmut and Sevilay Reyhanoglu

Dawna and John Rhoades

Robert and Nancy Rhonehouse

Diana Rice

Marilyn Rice

Hannah Richards

Ronald Richards ('73, DB)

Charles and Joan Richardson

Sabrina and John Ricks

Dennis ('95, WW) and Carol Riddle

Dominick Riggs ('o8, WW) 


\section{RE C OG N I T I O N O F G I V I N G}

Reynard ('o4, PC) and Jeanelle Rigues

Ralph Rill ('87, DB)

Amy Ringue

Charles ('84, WW) and Susan Rison

James and Cynthia Ritchey

Sebastian Rivas ('o7, WW)

Adrian Rivero ('oo, PC)

Dorotha Rizzuto

James and Doris Robak

Christopher Roberts ('92, DB)

Donna Roberts

Geoffrey ('83, DB) and Marla Roberts

Keith Roberts ('o1, WW)

Lisa ('98, DB) and Ryan ('98, DB) Roberts

William and Joanne Robertson

Matthew Robinson ('o7, WW)

Francisco Rodriguez

Christopher Rogers and Elizabeth Wilson Rogers

John ('89, '98, DB) and Gretchen Rogers

David and Stephanie Rojas

Bernard Roke ('68, DB)

Matthew ('95, DB) and Laura Roland

William Roleson

Roger ('82, DB) and Andrea Romaker

Amy ('o5, WW) and Jeff Romanelli

Jesse ('o4, DB) and Marisol Romo

Joseph and Jamie Rongo

David Rooker

Carol Rose

Hoke Rose and Cristi Silverberg-Rose

Robert Ross

Stephanie Rowe

Kendall and David ('89, PC) Roy

Ronald ('75, DB) and Margie Roy

Wanda Rudiger

Franklin ('85, WW) and Kathy Rudolph

Truman Rue

John Runnion and Kat Littlecreek

Daniel Rupple ('95, PC)

James and Elizabeth Rush

James ('93, WW) and Wendy Russell

Lawrence ('61, MC) and Susan Russell

Jay and Tammie Ryan

John ('79, '8o, DB) and Lee Ann Sabel

Steve and Paula Sainsbury

Fartun Salah ('o7, DB)

Erwin ('86, '88, WW) and Elma Samida

Michael ('o4, DB) and Heather ('o4, DB) Samp

Carl and Carol Samson

Greg Sanchez

Humberto Sanchez

Javier and Hilda Sanchez

Brian and Julie Sand

Sidney and Betty Sandifer

Philip ('89, DB) and Jody Sankovitch

Debra and Frank Santiago

Michael Sarnacki ('87, DB)

Samuel ('85, DB) and Terry Satterwhite

Daniel ('94, WW) and Alexandria Schlapia

Kenneth ('79, DB) and Sandra Schlecht

Greg Schmid

Allen and Wendy Schmidt

Lois Schneider
Leonard ('81, '85, WW) and Leticia Schoelkopf

Edward Schopperth ('85, WW)

Doug and Ali Schroeder

NaDean Schroeder

Thomas Schrum ('o8, WW)

Nichole ('97, DB) and Eugene Schwanbeck

Stephen ('oo, WW) and Renee Schwarz

Herbert and Rose Schweitzer

Norea Scoff ('o4, 'o6, DB)

Carolynne Seeman ('88, WW)

David ('98, WW) and Maureen Seigler

Jackson ('74, DB) and Brenda Seltzer

Michael ('o2, 'o6, WW) and Henrietta Semik

Hubert ('86, DB) and Sheryl Senter

Samuel Septembre ('o1, DB)

Christopher ('81, DB) and Frances Servis

Peter ('93, DB) and Megan Settemberino

Jeffrey Sexton ('o6, PC)

Derrick ('9o, DB) and Anne Seys

K. Kevin and Kristin Shamlou

Cynthia and Bruce Shannon

Vicki Sharon ('o2, WW)

Brian Sharrer ('o1, DB)

Adrian ('o2, DB) and Kelly Shaw

Tracy and John Shaw

Nathan Shelton ('o8, WW)

Ray and Paula Shelton

Arthur and Victoria Sheridan

Rennison Sherrett ('89, DB)

James Shew

Francis ('83, WW) and Chaluay Shimek

Rebekah Shook

Richard and Shirley Shook

Jonathon Shoop

Sally and Ronald Short

Morufu (' 88, MC) and Juliana Shotuyo

Richard ('87, WW) and Mary Siebert

William and Nancy Siems

Allen Sikes ('58, DB)

Chris Silman ('o8, WW)

Brian ('94, WW) and Margaret Simeone

Melinda Simon

Geoffrey and Diane Simonson

Stephanie Sipila ('97, DB)

Donald and Penelope Skaff

Andrze ('oo, WW) and Claire Sleboda

John and Leilia Slocum

Alison Smalling ('96, '98, DB)

Christopher Smith ('o6, DB)

Clifford and Geraldine Smith

Frank ('o6, WW) and Carla Smith

George ('69, DB) and Sylvia Smith

Hardy and Debbie Smith

James Smith

Roger and Penny Smith

Sharon Smith

Sid and Janet Smith

Steven ('o4, WW) and Sandra Smith

Alicia and Stephen ('95, DB) Smyth

Cordell ('96, WW) and Saundra Snow

Jessica Snow

Jean Snyder

Marshall and Donna Snyder
Richard ('89, WW) and Lenore Snyder Steven ('97, WW) and Debra Snyder Robert Somerville ('o2, WW)

Raymond ('97, WW) and Sandra Sommers

Frank and Carolyn Sovich

Leslie Speck

Alex Sperazza

Nick and Joan Spiroff

Aaron ('o7, 'o8, WW) and Beth Spotts

James ('o4, WW) and Marlene Spurlock

Sandrah Stack ('o1, '02, WW)

Klaus Staefe ('oo, WW) and Teresa Butler Staefe

Thomas and Bernice Stamford

Wencil and Rosemarie Stanek

Wesley and Joan Stanfield

Howard and Elizabeth Stange

Ruth Stanich

Bryan ('o3, WW) and Jan Stanton

Mike ('93, WW) and Kimberly Stasiewicz

Thomas Stayer ('98, DB)

Dan ('92, DB) and Susan Stearns

Ron Steele

Natalie ('o4, DB) and Scott Steinhauser

Larry and Brenda Stephan

Bruce (' 83, DB) and Sandra Stern

Amanda Stevens ('o2, DB; 'o8, WW)

Clyde and Diane Stevenson

Michael Stewart ('99, WW)

Lester and Elizabeth Stiel

Joel and Carolyn Stitt

John Stitt

Anthony Stobiecki

Anne and David Stokes

Kirk Stokes

Kyle and Diana Stokes

Thomas and Yvonne Stone

Daniel and Mary Ann Stotler

Les and Rosita Stotler

Ryan Stott ('o6, PC)

Charles ('74, DB) and Carol Stough

William ('93, WW) and Mary Strasser

Ira and Laura Strauss

Michael ('94, WW) and Anita Streicher

David and Cynthia Stucky

Donna and David Stutts

Richard ('91, WW) and Linda Suggs

Melvin ('97, WW) and Virginia Summe

Lewis ('8o, WW) and Donna Swain

Dean Sweeney

Thomas and Janice Sweeney

Lowell ('95, WW) and Tonya Syers

Megan Szymanski ('o6, 'o9, DB)

Steve Tackney

Samuel ('98, WW) and Mere' Taeu

Steven Taipale ('84, '95, PC)

William ('89, DB) and Catherine Tasi

Eugene (' 78 , DB) and Elizabeth Taylor

Allyn and Mary Taylor

John and Janet Taylor

Robert ('o5, WW) and Prakob Terhardt

Thomas Terrell

Elisa Marie Tesch

Jared Testa ('o1, PC) 


\section{REC OG N I T I O N O F G I V I N G}

\section{Cadets (cont.)}

Billy ('56, MC) and Helen Thayer

David Therneau

David Thomas ('o1, DB)

Dayl Thomas ('o2, DB)

Hugh ('91, PC) and Maria Thomas

Mark ('84, WW) and Vonna Thomas

Romeo and Florence Thomas

Bradley ('84, PC) and Rhonda Thompson

Dianne and Raymond Thompson

Jack ('o5, WW) and Mary Thompson

Sidney Thompson ('71, DB)

William ('86, DB) and Easter Thompson

Kathleen Thoreson

Ricky and Trudy Thornsberry

Richard Thurz ('67, DB)

Waldemar Tiedemann ('77, DB)

Daniel and Sandra Tocher

Andrew Tong ('97, WW)

John ('86, WW) and Eileen Topitzer

Marcos ('98, PC) and Deborah Torres

Teresa Toscano

Mary Lou Towner

Gene and Diane Townsend

Michael Traub ('98, WW)

David and Lisa Treusch

Peter ('88, DB) and Donna Trimarche

Robert and Nadean Trimyer

Larry and Jan Triplett

Eric ('o6, DB) and Paula Trivette

William and Paula Trivette

Thomas and Mary Lou Trousdell

Bruce Trout

Peter and Andrea Truslow

Marcos and Edna Tubola

George ('89, WW) and Deanna Tucker

David ('89, WW) and Rosa Tuemler

James and Charlotte Turner

Philip and Lois Turner

Rachelle Tuttle

Aaron Twigg ('o7, WW)

Richard ('75, '83, WW) and Janneth Ulm

Susan Valenteen ('o4, WW)

Jennifer Valenti

Randy and Judy Valicoff

Jean-Noel and Paula Vallejo

Eleuterio and Teresa Valles

Karl and Marion Van Allen

Maria Van DeMark

Patricia Van Duyne

Greg Van Noy ('9o, PC)

Sue Vandernald-Johnson

Jack ('81, WW) and Loraine Vandigriff

Mark Verdesco ('83, DB) and Linda Verdeseo

Hugh ('94, 'o7, WW) and Lara C. Verhoef

Brent Vertin ('o2, WW)

Thomas Vickers

Margaret Vickery

Oscar Villa

Miguel ('91, DB; '05, WW) and Raquel Villanueva

Ramiro Villarreal

Aleta Vinas ('84, '85, DB)

Kenneth ('87, DB) and Bernadette Vineburg

Anthony ('91, DB) and Laura Virili
Brian ('94, PC) and Laurel Visser

Christopher Vogel

Robin ('87, 'o2, WW) and Mary Vozar

Dale and Barbara Vranik

Joi ('oo, DB) and Kris Vutpakdi

Joseph and Patricia Waeschle

Joanne and Mark Wagenschnur

Blaise and Carla Waguespack

Cathy and Stephen Waits

William ('94, WW) and Kara Wales

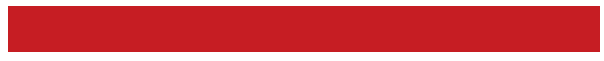

Our partnership with Embry-Riddle

is an opportunity for Tecnam to

demonstrate the quality of its plane

- its engineering and versatility - and

also to recognize Embry-Riddle's

program for its high level of quality,

training, and strict safety management.

This donation is our way of supporting and encouraging the next generation of general and commercial aviation pilots.

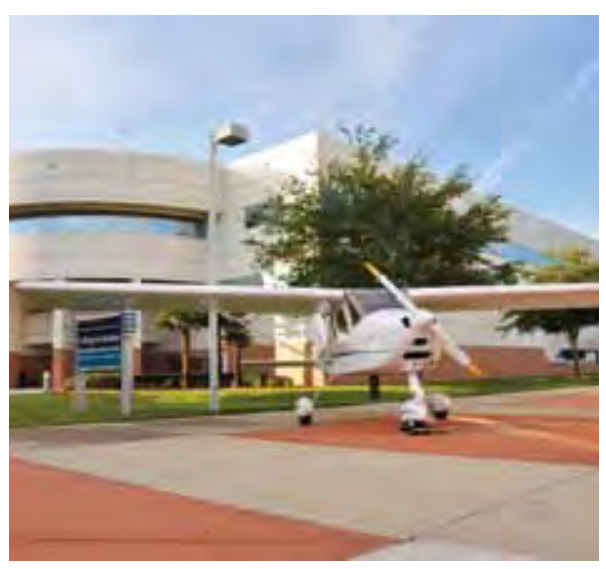

Lynne Birmingham, U.S. Distributor, Costruzioni Aeronautiche Tecnam Srl. on their donation of a 2009 Tecnam P-92 Echo Classic, a light sport aircraft (S-LSA) valued at $\$ 125,000$, to EmbryRiddle's nationally ranked Daytona Beach flight team.

Blair Walker ('o4, PC)

James Finton Wallace ('99, DB)

Eugene ('o2, WW) and Chong Wallner

Glenn ('88, WW) and Carol Walters

Robert ('92, WW) and Martha Ware

Joshua ('92, WW) and Trinidad Watkins

Roberta Watt

George ('75, WW) and Geneva Watts

Raymond and Patricia Weaver

Frederic Weeden

Mark ('86, PC) and Jodi Weems

Robert ('73, DB) and Shirley Weikel

Donald and Maryellen Weingarten

Irwin and Joan Weiss
Thomas ('91, DB) and Bea Weitzel

Abby Welch

Margaret Welch

Nicholas Welch

Frank and Nancy Wencel

Richard ('92, WW) and Lisa Westerfield

Richard ('88, PC) and Joy Westermeyer

James Whealan and Anne Hartung Whealan

Dore Wheetley ('94, PC)

Jeanne Whetstone

Kirsten Whetstone

Steven Whetstone

Mitchell Whetzel

Andrew ('97, DB) and Candace White

Justin and Kimberly White

Leon and Patricia Whitehurst

Derek and Pauline Whitfield

Robert ('42, WW) and Mary Whitney

Renae Whitt

Michael ('96, 'o8, WW) and Melissa Wieand

Craig and Jennifer Wieland

Curtis and Robin Wilber

Elliott ('o3, WW) and Dana Williams

Karen ('oo, 'o4, DB) and Joe Williams

Robert and Kristine Williams

Sharon Willson

David ('8o, DB) and Janet Wilson

Donald ('95, WW) and Debbie Wilson

Kerwin ('o5, WW) and Salee Wilson

Terrence Wilson

Karen Winkle

Gerald and Josephine Winterhalter William ('84, WW) and Carrie Wiscombe Joseph ('86, WW) and Betty Wisniewski John and Joan Wolfe

Larry and Barbara Wolfrum

Wylie Wong

Cory Woo and Merri Walters Woo

Jeffrey ('96, '99, WW) and Tracy Wood

Leonard and Jane Wood

George Woode

Shirley Woodruff

Harry ('oo, WW) and Jackie Woody

John ('95, WW) and Catherine Wright

Edward and Karol Wunk

John ('88, PC) and Valerie Yamashita

Steven and Gwenn Yaple

Rudy ('62, MC) and E. Jean Yontz

Kyle ('o5, WW) and Louise York

Brandon and Tamara Young

Daniel and Leslee Young

David ('62, WW) and Dorothy Young

John ('91, WW) and Sandra Young

Julie and Phillip Young

Ronald and Regina Younger

John ('99, DB) and Lori Yuzzolin

Derrick Zajac

Ronald and Gail Zeier

Stephen and Sylvia Zeigler

Ken and Tiffany Zellmer

Stephen ('81, PC) and Mary Lou Zmijeski

William ('78, DB) and Connie Zorc

Laurie Zugay ('94, WW) 


\section{Endowments: A Lasting Legacy Benefitting Students}

Endowment funds provide an opportunity to leave a lasting legacy at Embry-Riddle and benefit many deserving students. Established with a \$50,ooo minimum gift-or \$25, ooo for memorial endowments-earnings help permanently fund specific programs, scholarships, or professorships.

Investment and spending policies for Embry-Riddle's endowment funds are determined and managed by the Investment Committee of the Board of Trustees. With its longterm investment strategy, Embry-Riddle seeks fund growth that exceeds the inflation rate and the spending rate (payout), while also controlling the short-term volatility of the portfolio's results through diversification.
During challenging economic times, a fund may experience losses that place its market value below the original donated amount. In that event, no funds are paid out until it has recovered to a sufficient level to maintain its principal donation and meet the spending rate for that given year.

Embry-Riddle thanks all who have supported our students and faculty by establishing an endowed fund. Such gifts, while occasionally affected in the short term by market fluctuations, represent a powerful way to make a difference in the lives of students year after year. The following list represents those endowment funds established by donations of \$10,ooo or more:
Fund Name

AAEF Eugene Bullard Scholarship

AAEF Bessie Coleman Freshman Scholarship

AAR Ira A. Eichner Scholarship

Frank and Novie Adams Scholarship

Jay Adams and Jim O'Connor Scholarship for Student Leadership and Service

Alumni Legacy Scholarship

AOPA Career Pathways Scholarship

William Ashe Scholarship

Aviation Safety Chair

Robert W. Baker Memorial Scholarship

James W. and Essie W. Barfield Scholarship

James H. Bastian Scholarship

Edward and Jane Bavaria Scholarship

Raynald Bedard Memorial Scholarship in Aeronautical Science and Engineering

Stephanie Bellegarrigue Memorial Scholarship

Col. and Mrs. Warren A. Bennett ROTC Scholarship

Virginia T. Bingham Scholarship

Blanchette Scholarship for Excellence in Computer Science at Prescott

Braddock Educational Success Team (Best) Scholarship

Diedre Lynn Braim Scholarship

Brennan College Service Scholarship

James A. Bryan, Jr. Fellowship

Careers In Aviation Scholarship

Central Florida Alumni Chapter - Elizabeth P. Coley Scholarship

Cessna Scholarship

David M. Charlebois Memorial Scholarship
Total Donations

(as of 6/30/2009)
Market Value (as of 6/30/2009)

$\$ 13,171$

$\$ 6,159$

$\$ 14,593$

$\$ 100,000$

$\$ 94,972$

$\$ 319,634$

$\$ 33,274$

$\$ 224,665$

$\$ 12,977$

$\$ 128,421$

$\$ 120,565$

$\$ 458,280$

$\$ 12,000$

$\$ 54,177$

$\$ 30,000$

$\$ 10,109$

$\$ 25,000$

$\$ 100,000$

$\$ 11,102$

$\$ 25,000$

$\$ 10,000$

$\$ 280,000$

$\$ 76,200$

$\$ 75,000$

$\$ 117,890$

$\$ 110,000$

$\$ 39,515$
$\$ 19,008$

$\$ 101,851$
$\$ 133,820$ $\$ 280,263$ $\$ 64,643$ $\$ 221,246$ $\$ 14,788$ $\$ 315,879$ $\$ 133,661$ $\$ 507,754$ $\$ 11,277$ $\$ 52,832$ $\$ 29,921$ $\$ 9,658$ $\$ 47,065$ $\$ 91,088$ $\$ 12,587$ $\$ 23,253$ $\$ 11,012$ $\$ 375,601$ $\$ 82,829$ $\$ 64,103$ $\$ 145,600$ $\$ 106,877$ $\$ 42,052$ 
Fund Name

Bill Cody Scholarship

Commitment 2000 Scholarship

David Counts Memorial Basketball Scholarship

Elizabeth (Lisa) W. Cresenzo Scholarship

Army ROTC Scholarship in memory of Herbert C. Crosby

Tom Davis/Piedmont Airlines Scholarship

Andrew C. Deas Scholarship

Diamond Aircraft Scholarship

Kathleen P. Digan Memorial Scholarship

Linda S. Downs "Champions Of Character" Scholarship

Dr. Irwin Price Board of Visitors Scholarship

The George H. Ebbs, Jr. Scholarship

John and Audrey Eberle Scholarship

Philip H. Elliott, Jr. Scholarship

Embry-Riddle Florida License Plate Scholarship

Douglas Alan Eshleman Memorial Scholarship

John A. Fidel Aviation Scholarship

Dr. Leon E. Flancher Scholarship

Timothy P. Forte Memorial Scholarship

James David Frost Memorial Scholarship

R. Gagne/S. Budesheim Memorial Scholarship

Robert A. Goldberg, Jr. Scholarship

Samuel M. Goldman and Jack R. Hunt Scholarship

David J. Gonnion Memorial Scholarship

Mark V. Haas Scholarship

James Hagedorn EmpowerEd Daytona Beach Campus Scholar

James Hagedorn EmpowerEd Prescott Campus Scholar

Benjamin T. Hall Scholarship

Austin Harney Memorial Basketball Scholarship

Richard Harvey Scholarship

Dr. Albert D. and Toni D. Helfrick Scholarship

Helicopter Studies Book Award

Hillsdale Scholarship

James Holahan Aviation Communication Scholarship

Russell F. Holderman Scholarship

Holleyhawk Memorial Scholarship

Frank W. Hulse Scholarship

Jack Hunt Aviator Scholarship

International Order of Characters - Jim Crane Scholarship

Sharon Jones Scholarship

Cale M. Kastanek Memorial Scholarship

Peter V. Kinkade Memorial Scholarship
Total Donations

(as of 6/30/2009)

$\$ 30,765$

$\$ 46,409$

$\$ 12,345$

$\$ 116,625$

$\$ 12,025$

$\$ 42,445$

$\$ 617,028$

$\$ 25,000$

$\$ 11,590$

$\$ 254,175$

$\$ 26,500$

$\$ 99,508$

$\$ 11,710$

$\$ 12,238$

$\$ 36,946$

$\$ 72,280$

$\$ 18,860$

$\$ 17,764$

$\$ 25,021$

$\$ 10,027$

$\$ 39,029$

$\$ 14,250$

$\$ 31,496$

$\$ 95,859$

$\$ 63,267$

$\$ 100,000$

$\$ 100,000$

$\$ 10,000$

$\$ 19,733$

$\$ 10,000$

$\$ 59,829$

$\$ 12,122$

$\$ 50,000$

$\$ 17,000$

$\$ 249,534$

$\$ 10,320$

$\$ 16,485$

$\$ 88,797$

$\$ 125,175$

$\$ 15,204$

$\$ 13,900$

$\$ 51,048$
Market Value (as of 6/30/2009)

$\$ 46,536$

$\$ 67,772$

$\$ 15,970$

$\$ 107,088$

$\$ 10,512$

$\$ 57,177$

$\$ 640,622$

$\$ 26,982$

$\$ 19,153$

$\$ 241,434$

$\$ 24,138$

$\$ 96,211$

$\$ 26,097$

$\$ 18,818$

$\$ 200,526$

$\$ 76,215$

$\$ 30,032$

$\$ 22,695$

$\$ 33,926$

$\$ 17,964$

$\$ 9,334$

$\$ 16,291$

$\$ 42,258$

$\$ 106,638$

$\$ 42,006$

$\$ 97,641$

$\$ 97,641$

$\$ 12,485$

$\$ 19,529$

$\$ 13,114$

$\$ 60,454$

$\$ 12,222$

$\$ 58,780$

$\$ 24,119$

$\$ 29,540$

$\$ 8,928$

$\$ 26,581$

$\$ 100,407$

$\$ 151,331$

$\$ 22,819$

$\$ 14,311$

$\$ 60,75^{1}$ 
Total Donations (as of 6/30/2009)

Irma Kirk Scholarship

Ron Klotz Memorial Scholarship

C. Jeffrey and Katherine Knittel Book Fund

Leonard Kohn Memorial Scholarship

Jim Kolbe Scholarship

Todd Kraska Memorial Scholarship

Eilon Krugman-Kadi Memorial Scholarship

Moya and Bill Lear Scholarship

The American Airlines Durward "Duke" Ledbetter Scholarship

Arnold M. Lewis, Jr. Scholarship

Lyall Faculty Development

Robert E. Machol Scholarship

Edwin Marchetti Memorial Scholarship

William B. Masson Scholarship

Susan McCarthy Scholarship

John McCollister Aviation Writing Scholarship

McDonnell Douglas Foundation Scholarship

John G. and Isabel S. McKay Scholarship

Marie (Bee) \& John McMahon Scholarship

Stefan P. Meister Scholarship

George Mendonca Scholarship

Richard H. Merlin Scholarship

Charles O. Miller Memorial Scholarship

Alison Mills Memorial Scholarship

Miracle-Gro Scholarship

Elizabeth Lee Morrison Memorial Scholarship for Flight

D. Keith Mosing Business and Mangement Fellowship

D. Keith Mosing Family Scholarship

Frank H. Moxley, Jr. Scholarship

NARA Business Aviation Scholarship

Nicolai Scholarships

Lawrence E. Nix Memorial Scholarship

Linda Lu Notarpole Memorial Scholarship

Josephine O'Connor Memorial Scholarship

William F. and Dixie B. O'Connor Scholarship

Patrick B. Owens Memorial Scholarship

Amelia Peabody Aviation Fellowship

The Pinnacle Scholarships

Dr. Norval F. Pohl Memorial Scholarship

Pratt \& Whitney Scholarship

Prescott Flight Scholarship

Prescott Golden Eagles - Gehlert Scholarship
$\$ 15,017$

$\$ 11,275$

$\$ 17,500$

$\$ 22,050$

$\$ 56,873$

$\$ 11,075$

$\$ 10,800$

$\$ 195,000$

$\$ 16,530$

$\$ 11,305$

$\$ 50,271$

$\$ 12,536$

$\$ 10,000$

$\$ 40,000$

$\$ 11,801$

$\$ 10,600$

$\$ 40,000$

$\$ 426,613$

$\$ 37,000$

$\$ 10,115$

$\$ 100,000$

$\$ 17,395$

$\$ 20,000$

$\$ 10,489$

$\$ 144,455$

$\$ 11,728$

$\$ 65,000$

$\$ 100,000$

$\$ 80,911$

$\$ 26,572$

$\$ 27,264$

$\$ 35,000$

$\$ 21,360$

$\$ 68,559$

$\$ 40,207$

$\$ 12,000$

$\$ 100,025$

$\$ 16,000$

$\$ 29,011$

$\$ 12,500$

$\$ 12,826$

$\$ 11,170$
Market Value (as of 6/30/2009)

$\$ 29,368$

$\$ 11,234$

$\$ 19,591$

$\$ 19,326$

$\$ 63,362$

$\$ 10,816$

$\$ 9,869$

$\$ 190,900$

$\$ 26,030$

$\$ 11,981$

$\$ 67,384$

$\$ 20,972$

$\$ 17,589$

$\$ 41,724$

$\$ 18,985$

$\$ 11,046$

$\$ 28,982$

$\$ 644,458$

$\$ 38,070$

$\$ 11,490$

$\$ 96,709$

$\$ 19,714$

$\$ 21,080$

$\$ 12,609$

\$141,030

$\$ 11,046$

$\$ 60,986$

$\$ 96,318$

$\$ 118,265$

$\$ 23,111$

$\$ 34,446$

$\$ 35,244$

$\$ 26,779$

$\$ 80,589$

$\$ 53,913$

$\$ 40,669$

$\$ 152,223$

$\$ 18,665$

$\$ 32,617$

$\$ 20,210$

$\$ 15,852$

$\$ 14,503$ 
Fund Name

Kal Seshadri Purushotham Memorial Scholarship

Reserve Officers Association Scholarship

Mike Reynolds Memorial Scholarship

Steve and Vicky Ridder Scholarship

John Paul Riddle Memorial Scholarship

Robertson Aviation Safety Archive Student Assistantship

David and Andrea Robertson Scholarship

Harry Robertson Scholarships in Safety Science

Rolls-Royce Customer Business Scholarship

Charlie B. Ryan Scholarship

SAFE Association Scholarship

Paul E. Sanderson Scholarship

Johan Schwartz Memorial

James Shapiro Scholarship

David and Antoinette Slick Basketball Scholarship

Kenneth and Shirley Sliwa Memorial Scholarship

Steven Sliwa Scholarship

Philip Dalton "Flip" Smith Scholarship

R. Dixon Speas Scholarship

Captain Bill Stephens Memorial Scholarship

Robert Sweginnis and Michael Corradi Memorial Scholarships

Druria L. Sylvester Scholarship

Kenneth L. Tallman Scholarship

John R. Thomas Scholarship

Louise Timken Scholarship

Donald Topolinski Memorial Scholarship

Arthur F. Tweedie Memorial Scholarship

Richard Vagnozzi Memorial Scholarship

Lisa Wagner Memorial Scholarship

Fred E. Weick Scholarship

John Winant Scholarship

Women's Achievement Scholarship

Rawson Wood Scholarship

Gertrude V. Worthington Library Endowment

Edward P. and Olvena A. Yackel Scholarship in Aeronautical Science
Total Donations

(as of 6/30/2009)

$\$ 30,000$

$\$ 10,033$

$\$ 10,000$

$\$ 66,573$

$\$ 118,475$

$\$ 600,000$

$\$ 50,000$

$\$ 100,000$

$\$ 50,000$

$\$ 95,058$

$\$ 21,000$

$\$ 35,000$

$\$ 12,155$

$\$ 22,020$

$\$ 54,100$

$\$ 115,133$

$\$ 191,128$

$\$ 35,487$

$\$ 36,301$

\$10,000

$\$ 61,270$

$\$ 225,740$

$\$ 24,509$

$\$ 10,050$

$\$ 97,267$

$\$ 10,463$

$\$ 100,336$

$\$ 66,575$

$\$ 34,795$

$\$ 179,458$

$\$ 25,000$

$\$ 35,629$

$\$ 20,712$

$\$ 173,140$

$\$ 27,104$
Market Value (as of 6/30/2009) $\$ 33,706$ $\$ 18,309$ $\$ 17,565$ $\$ 77,608$ $\$ 153,914$ $\$ 499,063$ $\$ 43,476$ $\$ 109,904$ $\$ 50,393$ $\$ 95,673$ $\$ 35,257$

$\$ 44,397$ $\$ 13,402$

$\$ 29,729$ $\$ 48,915$ $\$ 119,986$ $\$ 269,658$ $\$ 42,492$ $\$ 37,902$ $\$ 11,469$ $\$ 62,280$ $\$ 253,799$ $\$ 34,286$ $\$ 10,615$ $\$ 116,521$ $\$ 18,719$ $\$ 88,954$ $\$ 79,379$ $\$ 35,414$ $\$ 201,610$ $\$ 35,201$ $\$ 50,857$ $\$ 52,748$ $\$ 186,562$ $\$ 29,531$ 


\section{To Soar Campaign $\$ 65,315,752$}

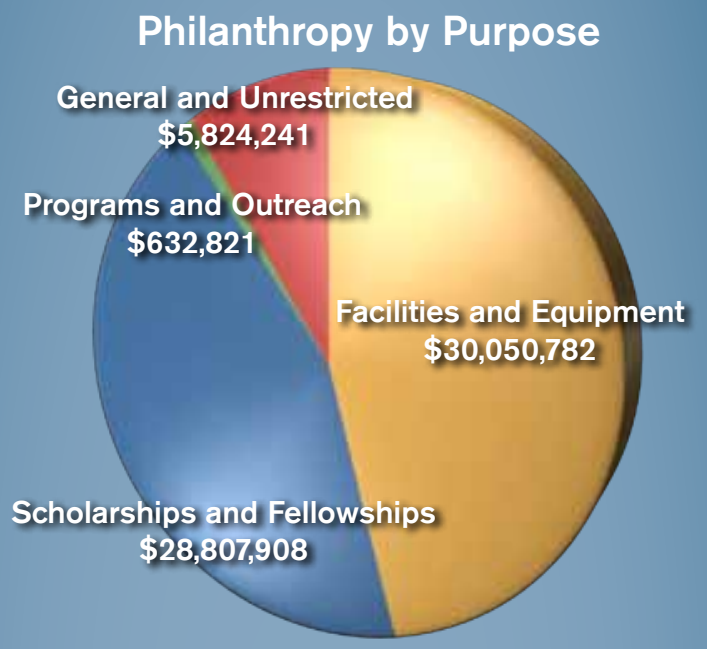

Philanthropy by Source

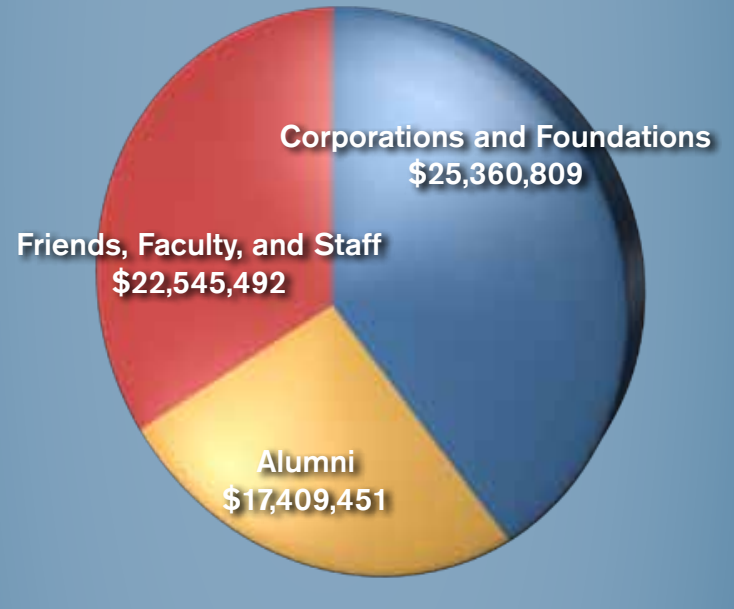

Philanthropy by Type

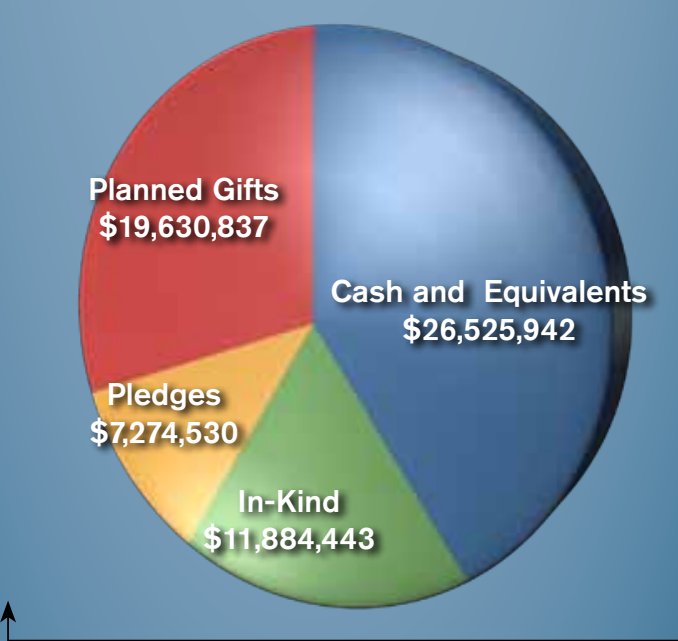

\section{To Soar Campaign Closes on High Note}

Embry-Riddle closed the books on its successful To Soar Campaign at the end of 2008, raising $\$ 65.3$ million in gifts and pledges.

"This is a high-water mark in Embry-Riddle history," says Embry-Riddle President John P. Johnson. "Thanks to the generous supporters of our To Soar Campaign, we have broadened and deepened the quality of the education we offer our students."

Johnson points to the more than $\$ 30$ million in donations pledged toward new facilities and an additional \$28.8 million directed to new scholarships and fellowships as leading indicators of Embry-Riddle's increased capacity and quality. "Coupled with our ongoing \$125 million investment in our residential and Worldwide campuses, we are better equipped than we've ever been to offer the best undergraduate education in aviation and aerospace in the world."

The culmination of the To Soar Campaign caps off a period of unprecedented financial support of Embry-Riddle. Jim Henderson, chairman of the Embry-Riddle Board of Trustees, credits President Johnson's leadership over the campaign's final two and a half years as a contributing factor.

"At no time in our history has Embry-Riddle enjoyed the unified support of so many people," Henderson notes. "During President Johnson's tenure, we have enjoyed the two best consecutive years of fundraising in our university's history. It is a testament to his leadership and vision that we end the campaign on such a resounding note."

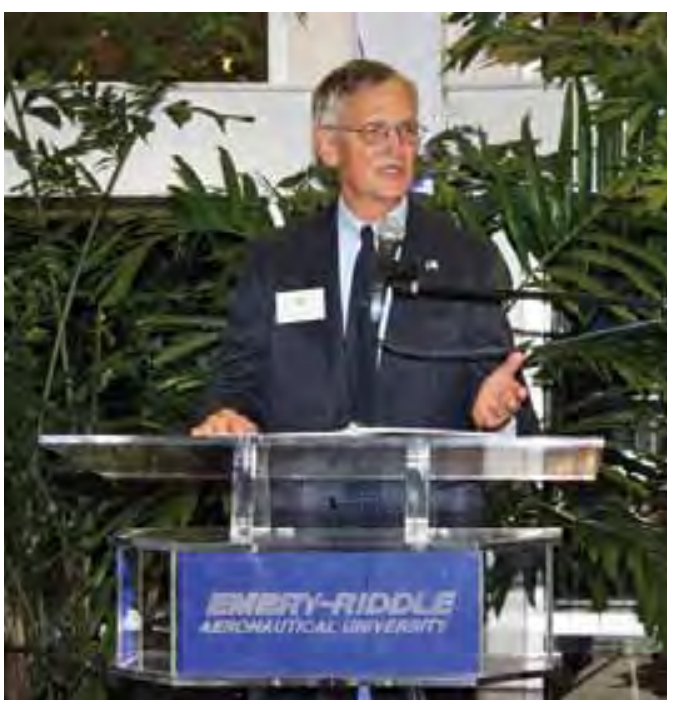

Embry-Riddle Development Committee Chairman and University Trustee, Jay Adams, addresses supporters at the December 2008 To Soar Campaign dinner celebration. Adams, who has been a supporter of Embry-Riddle since its move to Daytona Beach in 1965, helped lead the fundraising effort. 


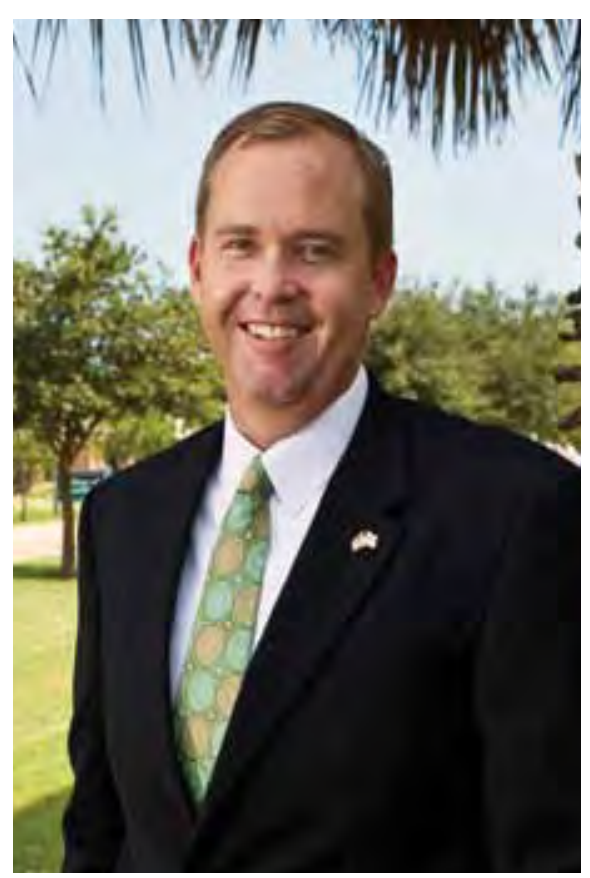

\section{United in support of students}

Even from the earliest days, aviation and aerospace have never been for the faint of heart. From the aviation pioneers who braved those first flights to the modern visionaries who are designing new planes, launching rockets and building business models that sustain global companies- all are united by a bold drive and determination to succeed in the face of great challenges.

Embry-Riddle students who come here-as it is often said-to "apply themselves rather than find themselves," share that drive and determination to achieve their dreams. Embry-Riddle students are typically engaged in applied learning experiences that you won't find at other undergraduate universities-whether it's launching a rocket 20 miles into space with the Icarus Project, building the nextgeneration, alternative-energy automobile with EcoCAR, or winning regional and national championships with our flight and athletics teams.

In partnership with our colleagues in financial aid, the development office has the distinct pleasure and honor of working to award scholarships to many of these students. We take this responsibility seriously and do this work on behalf of each donor. During the university's To Soar fundraising campaign, donors contributed more than \$7.2 million to create more than 200 new scholarship funds. These donations go directly to pay for a portion of tuition for deserving men and women, providing students a helping hand as they face their own challenges.

Our alumni play a key role in our ability to reach out to students as they strive to succeed. During our recent campaign, more than 5,00o alumni chose to make a donation to Embry-Riddle, even though these are tough economic times for many. That is an extraordinary statement of support for students.

And for your support we thank you! You've been an integral part of an exciting era for Embry-Riddle-an era of robust investment and ambitious plans for the future. It is an honor to present this third edition of the Lift philanthropy issue on behalf of our students and each of their dreams.

Sincerely,

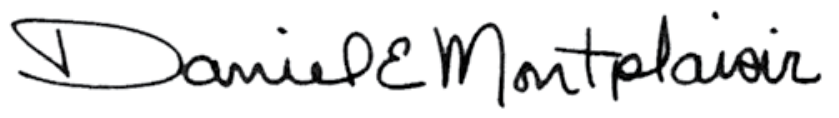

Daniel E. Montplaisir

Vice President

Office of Institutional Advancement 


\section{Contact the Office of Institutional Advancement}

Dan Montplaisir

Vice President

Institutional Advancement

386-226-4928
Bernadine Douglas

Assistant Vice President

Institutional Advancement

386-323-5090
Michele Berg

Executive Director

Alumni Relations

386-323-8025

\section{Board of Trustees}

Jim Henderson

Chairman of the Board

President and COO

Brown \& Brown, Inc.

Mori Hosseini ('79, '82, DB)

Vice Chairman of the Board

President

Intervest Construction, Inc.

Lawrence W. Clarkson

Secretary

President (retired)

Boeing Enterprises

Joseph Martin ('74, DB)

Treasurer

Office of the Chairman and Vice

Chairman of the Board (retired)

Fairchild Semiconductor

International, Inc.

John “Jay” C. Adams, Jr.

Executive Vice President (retired)

Brown \& Brown, Inc.
Eleanor Baum, Ph.D.

Dean of Engineering

The Cooper Union

Kenneth Dufour ('84, '89, WW)

President and CEO

Aviation Management

Consulting, Inc.

Jeffrey Feasel

President and CEO

Halifax Community Health

System

James Hagedorn ('79, DB)

Chairman, CEO

The Scotts Miracle-Gro Company

Karen Holbrook, Ph.D.

Vice President for Research and Innovation

University of South Florida

John 0’Brien ('68, DB)

Director, Engineering and Air

Safety (retired)

Air Line Pilots Association
Glenn S. Ritchey

Mayor, City of Daytona Beach

President and CEO

Jon Hall Automotive Group

David Robertson

Director

Michigan Aerospace Foundation

S. Harry Robertson, P.E.

President and CEO

Robertson Research Group

Mr. Jean G. Rosanvallon

President and CEO

Dassault Falcon Jet, Inc.

Louis C. Seno, Jr.

President

Jet Support Services, Inc.

Brig. Gen William W. Spruance

Chairman Emeritus

United States Air Force (retired) 
